\title{
LA CARTA DE SOR JUANA AL P. NÚÑEZ (1682)
}

En noviembre de 1980, exactamente tres siglos después de la composición del Neptuno Alegórico, apareció en un periódico de la ciudad de México la noticia de que don Aureliano Tapia Méndez, eminente eclesiástico de Monterrey, había encontrado una carta de Sor Juana Inés de la Cruz a su confesor, el P. Antonio Núñez de Miranda ${ }^{1}$. El año siguiente publicó Tapia su hallazgo, en edición de la Universidad Autónoma de Nuevo León. Esa carta constituye el tema y la materia del presente artículo².

${ }^{1}$ Junto con la noticia se publicaron (Exc, 12 y 13 de noviembre) algunos extractos, que alcancé a aprovechar en mi artículo "Para leer la Fama y Obras pósthumas de Sor Juana Inés de la Cruz", NRFH, 29 (1980), 428-508.

2 Emplearé las siguientes abreviaturas:

A. M. P.: Alfonso Méndez Plancarte, editor de Sor Juana;

BÉNASSY: MARIE-CÉCILE BÉNASSY-BERLING, Humanisme et religion chez Sor Juana Inés de la Cruz, Paris, 1982 (hay que tener en cuenta que la autora, al publicar este libro, no tenía conocimiento de la Carta de Sor Juana);

BERISTÁIN: JOSÉ MARIANO BERISTÁIN DE SOUZA, Biblioteca hispano-americana setentrional, $2^{\text {a }}$ ed., Amecameca, 1883.

Calleja: Diego Calleja, Vida de Sor Juana ("Aprobación” de la Fama y Obras pósthumas, Madrid, 1700);

Carta: la Carta de Sor Juana al P. Núñez, según el texto que aquí publico; CASTORENA: JUAN IGNACIO DE CASTORENA Y URSÚA, prólogo de la Fama y Obras pósthumas de Sor Juana;

CHÁvezi : EZEQUIEL A. CHÁveZ, Ensayo de psicología de Sor Juana Inés de la Cruz $y$ de estimación del sentido de su obra y de su vida... [en la pasta del libro: Sor Juana Inés de la Cruz: su vida y su obra], Barcelona, 1931;

CHÁveZ2: Id., Sor Juana Inés de la Cruz. Su misticismo y su vocación filosófica y literaria, México, 1968;

MAZA: FRANCISCO DE LA MAZA (ed.), Sor Juana Inés de la Cruz ante la historia, México, 1980;

MEdina: JOSÉ TORIBIo Medina, La imprenta en México, Santiago de Chile, 1908-1912; 


\section{SOR JUANA Y EL P. NÚÑEZ}

El primer testimonio sobre la relación entre Sor Juana y el P. Núñez es el del P. Diego Calleja en su Vida de la monja. Es. el momento capitalísimo de la "vocación" de Juana Ramírez. Descontada la retórica del elogio a la vida religiosa, tan preferible a la mundana - el propio Calleja, en edad madura, había abrazado la vida religiosa en la Compañía de Jesús-, lo que en esa Vida se dice es bien claro (además de que coincide punto por punto con lo que Sor Juana le dice a Sor Filotea en la Respuesta): Juana, criada de la marquesa de Mancera, no experimentó eso que técnicamente se llama "vocación religiosa". No se sentía "llamada por Dios"'s, sino por los libros. Su vocación era intelectual, y tan

OVIEDO: JUAN ANTONIO DE OVIEDO, Vida exemplar, heroycas virtudes y apostólicos ministerios del V. P. Antonio Núñez de Miranda, México, 1702;

"Para leer...": el artículo mencionado en la nota 1;

PAZ: OCtavio Paz, Sor Juana Inés de la Cruz, o Las trampas de la fe, $3^{\mathrm{a}}$ ed., México, 1983 (me refiero exclusivamente a esta $3^{\mathrm{a}}$ ed.; al aparecer las dos primeras, el autor no tenía aún conocimiento de la Carta de Sor Juana);

Respuesta: Respuesta de Sor Juana Inés de la Cruz a Sor Filotea de la Cruz, en $S J$, t. 4, pp. 440-475 (cito por número de línea);

SJ: Obras completas de Sor Juana Inés de la Cruz, ed. Alfonso Méndez Plan'carte y Alberto G. Salceda, México, 1951-1957;

TAPIA ${ }^{1}$ : AURELIANO TAPIA MÉNDEZ, Autodefensa espiritual de Sor Juana, Monterrey, 1981;

TAPIA ${ }^{2}$ : Id., Carta de Sor Juana Inés de la Cruz a su confesor, Monterrey, 1986;

Zambrano: Francisco ZaMbrano, S.J., "Núñez de Miranda, Antonio", en su Diccionario bio-bibliográfico de la Compañía de Jesús en México, t. 10, México, 1970, pp. 513-539.

${ }^{3} \mathrm{Al}$ hablar de la entrada en el convento, los hagiógrafos de monjas se dan vuelo: "Desde la más tierna edad nuestra heroína resolvió entregarse al Celestial Esposo", etc. (y el piadoso tópico encubrirá historias quizá interesantes). $\mathrm{Me}$ sorprende que PAZ, pp. 13, 90-91, etc., y BÉNASSY, pp. 166 y 168, encuentren "hagiográfico" y "beato" el tono de Calleja. PAZ da este ejemplo de "su método": "al contar que Juana Inés nació en una habitación a la que llamaban la celda, ve en esa circunstancia un aviso de su futura condición de monja". Yo no encuentro que ése sea su método. Calleja no hace sino contar un detalle que a él le ha contado en una carta la propia Sor Juana. Seguramente por estrecha y apartada, la habitación de la hacienda de Nepantla en que ella vino al mundo tenía esa designación familiar y humorística, la celda. Detalle curioso, puesto que Juana vino a parar justamente en una celda. (El propio PAZ no se salva de decir en la p. 124: " En la situación infantil ya estaban inscritos todos los pasos del destino de Juana Inés: la renuncia al matrimonio; la celdabiblioteca...'). El tono de Calleja no es propiamente hagiográfico sino al final, cuando habla de los dos últimos años de Sor Juana. Pero, ahí, ése era el único tono posible. No sólo cualquier religioso, sino cualquier laico devoto, tenía que ver en la "renunciación" de 1693 un acto heroico de virtud. 
honda, que nunca le pasó por la cabeza la idea de casarse ("total negación al matrimonio", dice la Respuesta). Excluido el matrimonio, no quedaba sino refugiarse en un convento, pues - dice Calleja- "la buena cara de una mujer pobre [y soltera, se entiende] es una pared blanca donde no ay necio que no quiera echar su borrón". Pero esta idea no le agradaba del todo a la joven: la vida conventual estaba llena de "obligaciones" difíciles de conciliar con el intenso deseo de dedicar la vida a la lectura y al estudio. Antes monja que casada, sí, pero... Así las cosas, Juana "comunicó los rezelos de su vocación" con el P. Núñez, y Núñez, jesuita al fin, "la quitó el miedo"': le dijo que su vocación intelectual podía conciliarse perfectamente con la vida de comunidad ${ }^{4}$, y entonces ella dio el gran paso. Por lo demás, así como Sor Juana le dice a Sor Filotea que no hubo solución de continuidad en sus estudios al pasar del "siglo" al claustro -inmediatamente después de contar cómo se hizo monja, escribe: "Volví (mal dije, pues nunca cesé), prosegui, digo, a la estudiosa tarea... de leer y más leer, de estudiar y más estudiar' (Respuesta, 290-293)-, así Calleja deja bien claro que Juana no dio ese paso para hacerse una santita. "Veinte y siete años - dice- vivió en la Religión sin los retiros a que empeña el estruendoso y buen nombrè de extática' (jamás se dijo de ella 'Hay en San Jerónimo una monja que tiene éxtasis'), "mas con el cumplimiento substancial a que obliga el estado de religiosa": lo estrictamente obligatorio ${ }^{5}$. Y el lector de esta Vida no vuelve a toparse con el nombre de Núñez hasta

${ }^{4}$ No cabe duda de que el esprit de corps ha sido una gran fuerza de los jesuitas. Calleja, hermano de sotana de Núñez, sabía muy bien lo que éste estorbó ulteriormente a Sor Juana, pero no mentía al decir que Núñez le había quitado a Juana sus "rezelos". He aquí cómo cuenta el resultado de la "consulta" que ella le hizo: "Siendo el consultado de tal familia [jla de San Ignacio!], claro estava que no le avía de parecer difícil caber dentro de vn alma tantos talentos de sabiduría hermanados con grandes virtudes religiosas". Sor Juana lo cuenta así (Respuesta, 280-282): "Esto [la consideración de los muchos estorbos que la vida conventual pondría a la libertad de mi estudio] me hizo vacilar algo en la determinación, hasta que, alumbrándome personas doctas de que era tentación, la vencí". Es notable cómo Sor Juana evita hacer público el nombre del P. Núñez, y lo pluraliza en personas doctas.

5 “"El mismo Calleja no tiene más remedio que reconocer, así sea a regañadientes [yo subrayo], la tibieza de Sor Juana", dice PAZ, p. 150.. Calleja, el poeta que en la "Elegía" publicada en la Fama y Obras pósthumas recuerda con emoción las misivas poéticas de Sor Juana, que no eran "espirituales" sino muy humanas (cf. "Para leer...", pp. 484-485, con las notas), escritas durante los años de "tibieza", mal hubiera podido reprocharle a su amiga el no ser una "extática". Por lo demás, Calleja añade que, en cuanto a observancia de lo estrictamente obligatorio, Sor Juana se portó "como la que mejor". 
el final, donde se dice que Sor Juana, ahora "ya otra", se dio de tal modo a la mortificación, que ni el prudente Núñez podía " a razones, a persuasivas y aun a ruegos, conseguir que templasse en sus penitencias el rigor"'.

La relación entre Núñez y Sor Juana constituye así un cuadro de armonía total, salvo el combat de générosité de los dos últimos años, cuando él trata de refrenar el furor sanctitatis de su hija espiritual y ella se obstina en salirse con la suya ${ }^{6}$. De este combate salió Núñez maravillosamente derrotado; él, que era un profesional de la santidad. La última imagen de Núñez que tiene el lector de Calleja es ésta: "Una vez le preguntaron los Padres [los de la comunidad jesuita de México]... que cómo la iba a la Madre Juana de anhelar la perfección" (curiosidad un tanto indiscreta, se diría), y Núñez contestó: "Juana Inés no corre en la virtud, sino buela'"7.

Sin más guía que la Vida de Calleja, un escritor mexicano de mediados del siglo XIX podía perfectamente pintar el cuadro de la relación entre Núñez y Sor Juana con estos colores:

Sobresalió mucho el P. Núñez en la gracia con que le dotó el Señor para dirigir las almas, especialmente a las religiosas. De su prudencia (ha escrito un moderno articulista) no es prueba tan concluyente su buen gobierno en calidad de rector del Colegio Máximo

6 La manera como Calleja cuenta este "pleito" se parece mucho a la manera como Sor Juana cuenta (Respuesta, 817 ss.) el que una vez tuvo con los médicos que le prohibían el estudio a causa de "un grave accidente de estómago": ella, con razones médicas, los había dejado mudos (así, sin el alivio de los libros, "eran tan fuertes y vehementes mis cogitaciones, que consumían más espíritus en un cuarto de hora que el estudio de los libros en cuatro días"). Lo que en los dos últimos años quería era morir, y debían sobrarle razones religiosas para triunfar de la "prudencia" del confesor.

7 Según BÉNASSY, p. 166, el relato de Calleja no nos dice gran cosa sobre lo que ocurrió realmente en el alma de Sor Juana, puesto que él habla como hagiógrafo y, además, "il est tout le contraire d'un témoin oculaire". No fue testigo ocular, pero tampoco se merece ese enfático tout le contraire. Los testigos de México lo tenían al corriente. Las palabras de Núñez, desde "Es menester mortificarla para que no se mortifique mucho..." hasta "...no corre en la virtud, sino buela", van impresas en cursiva, que era como se marcaba la literalidad de una declaración. (También está en cursiva el famoso comentario de Mancera sobre cómo se lució Juana ante los cuarenta sabios que la examinaron. En esos casos empleamos ahora más bien las comillas). BÉNASSY, por lo demás, observa sensatamente en otro lugar (p. 216): "on est obligé de constater que le Père Calleja... est aussi concis qu'admiratif lorsqu'il évoque cette période, se contentant de parler de progrès très rapides vers la sainteté..."; -contentándose, diría yo, con referir las noticias que por esos tiempos le llegaron a él desde México. Cf. "Para leer...", p. 503, nota 163. 
y de provincial, como la dirección espiritual de la célebre poetisa... Otro que no fuera el P. Núñez, habría violentado su inclinación a las letras humanas, reduciéndola al Kempis ${ }^{8}$ y a otros autores ascéticos; pero este jesuita supo conciliar los santos carismas de un Esposo sobrenatural y los entretenimientos del juicio con la imaginación. La veía pasar del monte Oreb al Parnaso, y, como no la encontraba pervertida con las ilusiones de la fábula, consentía que volviese a abastecerse de imágenes sublimes para explicar sus pensamientos ${ }^{9}$.

Si hacemos abstracción de la cursilería del lenguaje, veremos lo justificado de ese cántico a la cordura y delicadeza de Núñez. Sor Juana, monja, escribió poesías "humanas" de calidad extraordinaria; otro que Núñez no hubiera tolerado ese revolotear de un monte a otro, del sagrado Oreb al pagano Parnaso. Núñez vio que el Parnaso no sólo no "pervertía" a su hija espiritual, sino que la "abastecía" de joyas poéticas. Todo lo que ella escribió fue consentido por él. ¡Gran hombre!

Quien acabó para siempre con este cuadro color de rosa fue Ezequiel A. Chávez en su Sor Juana de 1931. Él parece haber sido el primer lector moderno de la Vida de Núñez por el P. Juan Antonio de Oviedo ${ }^{10}$. Esta Vida se publicó en 1702, inmediatamente después de aparecida la Fama y Obras pósthumas, cuando Sor Juana era leída y aclamada en los dos mundos. Como Núñez había tenido tanto que ver con ella, el asunto bien se merecía todo un capítulo

${ }^{8}$ De hecho, Núñez es autor de una Explicación theórica y práctica aplicación del libro quarto del Contemptus mundi, para prepararse y dar fructuosamente gracias en la frequente comunión, impresa en 1691 en Puebla, por el mismo Diego Fernández de León que el año anterior había impreso la Carta Athenagórica y la reprensión de Sor Filotea. Dice BERISTÁIN que en esa Explicación (que él llama Exposición) hace Núñez "una erudita apología de Tomás de Kempis, verdadero autor del precioso libro De imitatione Christi, contra los que lo atribuyen a Juan Gersón". (Núñez fue durante toda su vida ministerial un verdadero apóstol de la comunión frecuente).

9 José MaRiano Dávila, "Núñez de Miranda, P. Antonio", en el Diccionario universal de historia y geografía (adaptación mexicana del de F. de P. Mellado), t. 3 de Apéndices, México, 1856. Tomo la cita de Zambrano, p. 535. (Sobre los cargos de rector y provincial de Núñez cf. infra, p. 639).

${ }^{10}$ Oviedo, bogotano, se trasladó a los 20 años (en 1690) a México, donde se hizo jesuita y vivió hasta su muerte (en 1757). Oviedo tuvo a su vez su biógrafo-hagiógrafo, el también jesuita FRANCISCO XAVIER LAZCANO (Vida exemplar y virtudes heroicas del $V$. P. Juan Antonio de Oviedo, México, 1760), donde leemos que "quien ganó los primeros respetos y religiosos cariños al [recién salido del noviciado] hermano Juan fue el V. P. Antonio Núñez de Miranda". Núñez, su padrino de primera misa, fue asistido por él en el lecho de muerte (ZAMBRANO, p. 533). 
(que puede leerse cómodamente en BÉNÁSSY, pp. 434-437). Allí revela Oviedo lo que Calleja había callado. Dice que Núñez quiso "contener el natural affecto e innata inclinación a las letras de la Madre Juana en los límites de una decente y moderada ocupación, para que del todo se dedicasse al estudio de la perfección", que era, naturalmente, "lo que qualquier prudente y acertado padre de espíritu debía hacer" en el caso de una monja hija suya. Y en seguida, dándonos a sobreentender un nexo que sería más o menos: 'pero la monja en cuestión no toleró barreras de contención en su natural afecto', continúa: "Viendo, pues, el P. Antonio que no podía conseguir lo que deseaba, se retiró totalmente de la assistencia a la Madre Juana',; no pudiendo con ella, la abandonó a su (desdichada) suerte ${ }^{11}$.

Chávez aprovechó al máximo ese revelador capítulo. Casi se siente que lo sabía de memoria. Pero también leyó atentamente el resto de la Vida, para hacerse del personaje la imagen más fiel posible y comprender y explicar mejor el "choque de almas" tan sucintamente contado por Oviedo12. Además, fue Chávez el pri- mero que leyó una obra de Núñez, la Distribución de las obras del día, donde se explica circunstanciadamente cómo debe ser la vida de las monjas. Estaba, pues, muy bien informado sobre esas dos almas, y el "choque" lo dejó fascinado:

¡Oh! ¡cuán diferentes, aunque, en algún sentido, cuán semejantes, Sor Juana... y su confesor!...: los dos igualmente sinceros en sus convicciones..., los dos admirables en su devoción y en las obras que hicieron; pero ¡cuán diferentes esas obras, y el concepto

11 La Carta descubierta por Tapia “confirma" la ya muy sabida ruptura, pero "aclara" que quien se retiró fue Sor Juana, y en esto radica, evidentemente, su principal interés. Claro que la iniciativa bien hubiera podido ser de Núñez. Era muy capaz de "despedir" hijos espirituales. Uno de ellos, Domingo Pérez de Barcia, "pecó" por el lado inverso del de Sor Juana: cayó en el misticismo; comenzó a entenderse directamente con Dios "en el trato interior" y a "experimentar algunas cosas sobrenaturales de divinas comunicaciones y otras semejantes", a las que Núñez, campeón de la religiosidad "práctica", era profundamente adverso (JULIÁN GUTIÉRREZ DÁVILA, Vida... del V. P. Domingo Pérez de Barcia, Madrid, 1720, citado por BÉNASSY, p. 227). Sobre este episodio véase CHÁVEZ ${ }^{2}$, p. 165 , el cual muestra gran conmiseración por el estado en que quedó Pérez de Barcia tras el abandono.

${ }^{12}$ Chávez era un experto en psicología. El título de su libro de 1931 es Ensayo de psicología. Sus conocimientos eran los tradicionales, los llegados del siglo XIX, todavía sin Freud. De lo cual debemos felicitarnos: su libro está lleno de cosas aprovechables (más que el de Amado Nervo), mientras que la atropellada extravaganza pseudo-freudiana de Ludẉig Pfandl a lo único que mueve es a risa. 
de vida mejor que a cada uno de ellos guiaba!... [Vidas] que ya se alejan, ya se ponen de acuerdo; divergiendo, convergiendo, o recíprocamente tolerándose; no, nunca, en cabal y bien acordada inteligencia recíproca... ¿Cómo pudo Sor Juana..., espontánea y fugaz..., confesarse años y años, desde su niñez, su vida entera ${ }^{13}$, con el hombre que era todo orden y regla, método y rigor?... Imposible que el P. Antonio... no haya visto que sin cesar se escapaba ella a su dirección. Creyéndola conquista suya para el Cielo, imposible que no se haya desazonado cuando la miraba de repente pensar lo que él no pensaba, sentir lo que él no sentía, decir lo que él no soñaba que pudiera pensarse, que pudiera sentirse, que pudiera decirse. Y su voluntad firme y su decisión resuelta, imposible que no le parecieran burladas por aquella mujer de voluntad tan libre y alada, por más que tan sinceramente ansiase siempre subordinarse con la más dulce y confiada sumisión... ${ }^{14}$

Subrayo el triple imposible para llamar la atención sobre lo bien que leyó Chávez el relato de Oviedo, objetivándolo hasta donde pudo, quitándole su tufo hagiográfico. Según Oviedo, "se han engañado muchos" con la idea de que Núñez "le prohibía a la Madre Juana el exercicio decente de la poesía", cosa falsa - dice-, pues un varón tan sabio y tan santo jamás hubiera podido prohibir algo "santificado con los exemplos de grandes siervos y siervas de Dios". Chávez siente que la refutación no corresponde muy bien al "engaño" en que muchos estaban en cuanto a Núñez (pues es claro que si alguien hubiera salido con el cuento de que Núñez le prohibía a Sor Juana el ejercicio de la poesía santa, no habría podido "engañar" a nadie). Y Oviedo insiste algo después: "parece no ha faltado quien califique de demasiado severo" a Núñez... Chávez supo interpretar muy bien la insistente defensa: tanto humo es señal de lumbre.

Quizá el libro más "ultramontano" que se ha escrito sobre Sor Juana es el que publicó el raro Genaro Fernández MacGregor, en forma de comentario al libro de Chávez, un año después ${ }^{15}$. Se trata de una anti-tesis en toda forma. Fernández

${ }^{13}$ En realidad, no "su vida entera", según se ve por la Carta. Ni tampoco "desde su niñez": de la Carta se deduce que Sor Juana conoció a Núñez poco antes de entrar en el convento, quizá a mediados de 1667, cuando ella tenía 18 años cumplidos. (Chávez, naturalmente, pensaba todavía que Sor Juana había nacido en 1651).

${ }^{14}$ ChÁvez 1 cap. 34 ("Sor Juana Inés de la Cruz y su confesor..."), pp. 375-396. Pero Núñez reaparece en otros lugares del libro, lo mismo que en CHÁVEZ ${ }^{2}$.

15 Genaro Fernández MACGREgor, La santificación de Sor Juana Inés de la Cruz, México, 1932. 
MacGregor reabre el caño hagiográfico de Oviedo y prescinde totalmente de la rejilla discriminatoria de Chávez. Para que haya verdadero choque de almas - viene a decir - es preciso que las dos almas estén a la misma altura; pero, desde luego, la "altura mística" de Núñez "era mayor que la de su hija de confesión" (p. 65). Por lo demás, Núñez no era inflexible (p. 90), sino que, "como todos los místicos, sabía la importancia que para la unión con Dios tiene la regla y el ritual" (p. 97). Una monja disipada no llega a esa unión y por consiguiente es mala monja. Sor Juana dejaba mucho que desear. Toda la razón estaba de parte de Núñez ${ }^{16}$. En resumen: Chávez, psicólogo positivista interesado en la evolución espiritual de Sor Juana, no tiene derecho a reprobar la conducta de Núñez. "Los que sí pueden tal vez juzgar severamente la intervención del $\mathrm{P}$. Antonio son los amantes de la mera poesía" (p. 115).

Chávez, visiblemente herido, se puso a escribir sin pérdida de tiempo una réplica a su contradictor, de la cual no publicó sino un "avance". Al morir (en 1946), su réplica es todo un libro, publicado póstumamente ${ }^{17}$. Ha vuelto a leer y releer los documentos, en especial la Vida de Núñez, e insiste punto por punto en su visión de las cosas. Vuelve a copiar, por ejemplo, este pasaje de la libreta de apuntes de Núñez, transcrito (como otros muchos) por Oviedo: "El súbdito es instrumento del superior. No tiene el instrumento

16 ALFONSO JUNCO, que durante años fue la "gran" figura del reaccionarismo intelectual católico, decía en un artículo de 1932 (recogido en su libro Gente de Méjico, 1937, pp. 151-157) que el libro de Fernández MacGregor era "una justa apología [del] confesor, pero una injusta desestimación de la monja". -Por exceso o por defecto, muchas de las visiones modernas de Sor Juana carecen de la exactitud de Chávez. He aquí un muestrario: SALVADOR Gallardo Dávalos, Santa Juana de Asbaje, Poema dramático en tres cuadros, Aguascalientes, 1956, presenta a Núñez como bestia negra de rigor y fanatismo (él y otros personajes masculinos, como Sigüenza y Góngora, entran en la celda de Sor Juana como Pedro en su casa); FREDO ARIAS DE LA CANAL, Intento de psicoanálisis de Sor Juana Inés, México, 1972, dice que Sor Juana transfirió la imagen materna cruel (madre rechazante, negadora de leche) al severísimo Núñez, si bien el que consiguió “desmoronar las defensas de Juana” ( $p$. 93) haciéndola renunciar a la poesía fue el arzobispo Aguiar y Seixas; DARIO PUCCINI, Sor Juana Inés de la Cruz, Studio d'una personalità del Barocco messicano, Roma, 1967, cree, en cambio, que el "desmoronamiento" fue obra del obispo Fernández de Santa Cruz. En esta última visión, como en la del simplista CASTORENA (cf. "Para leer...", pp. 497-499), resulta perfectamente prescindible Núñez.

17 CHÁVEZ, en cuyas últimas páginas se reproducen las "Notas sobre puntos y aspectos controvertidos de la vida y obra de Sor Juana Inés de la Cruz", publicadas originalmente en $U M x$, 1933, núms. 25/26. 
más valor que la sujeción al agente..., aunque se quiebre en la demanda..., [pues] para eso es", y comenta (p. 159): "Violentas expresiones..., palabras excesivas..., peligrosas para quien las profiere...; y para quien las oye, y las toma al pie de la letra, peligrosas también". Núñez "no siempre tuvo sentido suficiente de la gran verdad que consiste en que es imposible formar almas si no es de acuerdo con ellas mismas"' (p. 173)18.

Fernández MacGregor hubiera podido contrarreplicar tachando de anacrónico el juicio de Chávez: eso que un hombre moderno encuentra "violento", "excesivo" y "peligroso" no era tal para quienes vivían en el siglo de Sor Juana, sino cosa muy buena y muy santa. La visión del súbdito (una monja) como instrumento sin más valor que la "sujeción" a quien lo utiliza (el padre espiritual) era un lugar común en la retórica de la "perfección" a que las monjas debían aspirar. Núñez habla el lenguaje de sus tiempos, y Oviedo, al copiar la frase "'aunque se quiebre, pues para eso es', sabe que los lectores la van a encontrar fuerte, sí, pero tanto más admirable por ello. ¡A qué extremos llevaba ese santo varón su celo por la santificación de las religiosas! Yquien así sentía no era un bobo ni un irresponsable, sino toda una lumbrera.

\section{EL P. NÚÑEZ: SU PERSONA Y SUS DOCTRINAS}

No se puede apreciar la fuerza de la recién descubierta Carta de Sor Juana sin saber qué clase de hombre fue el P. Núñez. Su Vida por el $\mathbf{P}$. Oviedo no es de fácil acceso - bien merecía una reedición, con buen prólogo y buenas notas-, pero lo esencial de ella ha pasado ya a los mejores estudios modernos sobre Sor Juana ${ }^{19}$. Sólo llamaré la atención sobre ciertos rasgos que me parecen significativos.

A lo largo de unos treinta y cinco años -más o menos desde 1660 hasta su muerte, a la edad de 77, en 1695-, Núñez fue un personaje sumamente destacado en la ciudad de México. Gozaba fama de sabio y de santo, y la gozaba de veras, quiero decir que

${ }^{18}$ No son pocos los puntos de crítica sorjuanina en que Chávez abrió brecha, pero el que más le inquietó - más aún que el de la venta de la biblioteca y la renuncia final - fue el de la relación de Sor Juana con su confesor. Sus dos libros llevan como epígrafe estas palabras de Paul Hazard: "El sentido de la variedad de las almas conduce a la tolerancia, y la tolerancia a la paz".

${ }^{19}$ Además de los de CHÁvEZ, son especialmente útiles - cada uno a su manera- PAZ, pp. 582-591 et.passim, y BÉNASSY, pp. 165-178 et passim. 
era muy consciente de ella. Así lo dicen los documentos. Era un "tragalibros"' (helluo librorum); tenía una memoria prodigiosa; sabía opinar acerca de todo, etc., etc., ¡y qué santidad la suya! Se desvivía por el socorro de los pobres; era el enamorado número uno de la Purísima Virgen; los martes, en honra de ella, fregaba en la cocina los platos sucios de la comunidad; era humilde y mortificado, etc., etc., iy qué inteligencia prodigiosa la suya! Establecida la doble fama, Núñez no podía sino cultivarla y acrecentarla. Para exhibir conocimientos hace falta público, y él lo tenía asegurado (además, en 1682, cuando le llegó a las manos la Carta de Sor Juana, llevaba publicadas unas veinte obras). Pero también la santidad se exhibe. El fregar platos y los demás actos virtuosos de Núñez no carecían de testigos, y sus palabras delatoras de gran santidad tenían siempre orejas en que caer ${ }^{20}$. El cartapacio en que registraba para sí mismo sus pasos en el camino de la santidad - los secretos que iba descubriendo, los progresos que iba haciendo- da la impresión de haberse escrito para la posteridad.

20 ¿Cómo, si no, podría un santo llevar a cabo la necesaria tarea de "edificación'? He aquí un rasgo de la Vida de Santo Tomás de Villanueva por Quevedo (Prosa, ed. L. Astrana Marín, Madrid, 1941, p. 1045b): “Dio a un pobre la cama en que estaba; $y$, acordándose de que por habérsela ya mandado no era suya, sino del pobre, le dijo: «Hermano, dadme licencia para morir en esta cama vuestra; si no, bajaréme a morir en el suelo, y acercaréme más a la sepultura». Fueron palabras éstas que derritieron los corazones de todos" (habría buen número de circunstantes). Y he aquí lo que cuenta CASTORENA acerca del arzobispo Aguiar y Seixas: antes de morir, "movido quizá" por aquello mismo que había movido a Sor Juana, vendió "por sí proprio" su biblioteca, y "dezía a varios Doctores que se la compramos: «San Nicolás Obispo vendió sus libros para dar limosna a los pobres; en la calamidad del tiempo me falta qué darles, vendo los míos. Quando huviere menester estudiar, no me hará V.m. favor de prestarme los suyos?"Enagenó aquel mes todas sus alhajas, hasta las vinageras, y... pocas horas antes de su fallecimiento vendió su cama, derramando a los mendigos su corto precio (imitando en esto a Santo Thomás de Villanueva) y murió con el consuelo su caridad fervorosa de acabar sin descanso, para bolar más prompta al eterno. ¡O gran Dios, siempre admirable en sus Escogidos!" - Vale la pena reflexionar en el papel de los circunstantes. Si, por ejemplo, Castorena y los demás doctores le hubieran impedido al amado arzobispo deshacerse de sus libros, destinando el dinero de la compra al socorro directo de los pobres, lo habrían echado todo a perder. Además, es interesante ver cómo el deshacerse uno de sus libros pasa a ser señal de santidad. JOSÉ MARIANO DÁVILA (mencionado supra, p. 595, nota 9) cita una conocida expresión de humildad de Núñez, que se remonta probablemente al año 1677 (cf. infra, nota 25), pero la sitúa en sus últimos días, cuando, casi ciego, dizque legó al Colegio Máximo "todo el arsenal precioso de su biblioteca particular", con admiración de todos. (La venta de la biblioteca y los demás bienes de Sor Juana no fue tan espectacular. No hubo testigos). 
Ese cartapacio pasó a manos de Oviedo, y de él proceden las sentencias o reflexiones espirituales (frases generalmente breves, muy bien redondeadas) que el biógrafo esparce en las páginas de su libro. Por ejemplo: "Toda mi medra consiste en hacer con perfección las obras ordinarias, como quien no tiene otra cosa que hacer ni negocio de importancia, como si sólo para esto me hubiera Dios criado y por ello redimido, como quisiera haberlas hecho a la hora de mi muerte y ante el tribunal de Dios"'21.

Núñez "fue ante todo una figura pública, respetada y temida. Como calificador de la Inquisición era el guardián de la doctrina ${ }^{22}$; como prefecto de la Purísima, su ministerio se ejercía principalmente sobre la aristocracia o, más exactamente, sobre el grupo gobernante... Entre los asistentes [a las pláticas de Núñez en la

${ }^{21}$ Una reflexión como ésta hace pensar en la Petición en forma causídica de Sor Juana (SJ, t. 4, pp. 520-521), la más importante de las piezas que compuso en el santo final de su vida, y la más intragable para el lector moderno. Véase PAZ, pp. 594-595, que la llama "consternante documento", y sobre todo CHÁVEZ1, pp. 404-407, aún más enérgico: "se diría... que quien la firma hubiese perdido el juicio". Llega a creer Chávez que Núñez se la dictó y ella "tuvo que copiarla" porque era la condición para "congraciarse" con él. "La certidumbre de que tal obra no es suya culmina al ver la forma en que está escrita, en la cual, de las 625 palabras que la componen, casi la mitad -298constituyen frases hechas, de la más vulgar jerga jurídica'’. Yo veo de otra manera este asunto (cf. "Para leer...", p. 497, nota 149). Precisamente la enorme proporción de voces técnicas delata el cuidado por la forma (causídica). La Petición es una pieza muy escrita, un verdadero pezzo di bravura. El asunto será cavernoso, pero la coquetería literaria de la monja - "genio y figura..." sigue viva. (Podría pensarse que, así como Sor Juana superó a Vieira en la Crisis, así en la Petición intentó superar a Núñez).

22 Mejor dicho, uno de varios guardianes. Núñez era ya calificador del Santo Oficio en 1660 (véase el documento publicado por ZAMBRANO, p. 519). Cuando había junta de calificadores, hablaba "con tal energía de palabras... y con tanta autoridad y eficacia..., que hacía retroceder a otros gravísimos y doctísimos calificadores" (OVIEDO). Pero los frutos de esta actividad no son muy vistosos. Se conocen unos veinte libros - entre ellos la Primavera indiana (1668) de Sigüenza y Góngora- que llevan "censura”, "aprobación”, "parecer" o "sentir" de Núñez (tarea bastante insulsa). Se conserva un ejemplar del Bien del estado religioso de Jerónimo Plati (Medina del Campo, 1595) que lleva nota y firma de Núñez: "Corregido conforme al Índice de 1632" (ZAMBRANO, p. 530). No eran tiempos de agitación religiosa. El Diario de Robles dice que el 9 de septiembre de 1677 " hubo auto en la sala del Santo Tribunal, de un hermitaño de la Puebla, por embustero; remitiéronlo al P. Antonio Núñez, que lo industrie en la doctrina"; en 1678 fue "relajado", por hereje, un fray Francisco Manuel de Cuadros, "aunque a última hora no fue quemado vivo, por señales que tuvo de arrepentimiento, y haber sido absuelto por el P. Antonio Núñez"' (ZaMbrano, p. 524). 
Purísima] se encontraban los oidores, los inquisidores, los prebendados y los caballeros de primera magnitud ${ }^{23}$... El ascendiente de Núñez de Miranda sobre sus oyentes y, a través de ellos, sobre la sociedad entera, era realmente extraordinario"' (PAZ, pp. 582-583). No son raras, desde luego, las figuras de ese tipo en el mundo hispano-católico de la época. Piénsese, por ejemplo, en un personaje sevillano de los primeros decenios del siglo, el P. Diego Ruiz de Montoya, jesuita como Núñez, “bien conocido por sus doctísimos escritos, y más por la opinión de religiosísima vida, ciencia y santidad, que le granjearon tanto crédito en Sevilla, que vino a ser el oráculo de aquella ilustrísima ciudad, donde ninguna cosa de importancia se resolvía sin su consejo" ${ }^{24}$. La técnica usada en el retrato de estos personajes es siempre la misma. El vocabulario se repite: ciencia y santidad, crédito, oráculo de la ciudad. Pongamos a México en vez de Sevilla y tendremos la efigie de Núñez. Lo básico es la fama de ciencia-santidad, que a Núñez se le reconoció en letra de molde ya en 1676: "Pater Antonius Nuñez de Miranda, natione Mexicanus, virtute ac litteris insignis"' 25 . Tenía toda la razón Calleja al decir que Núñez "era... en

${ }^{23}$ La Congregación de la Purísima, dice BÉNASSY, p. 257, estaba “composée de laïcs pieux". De laicos y también de eclesiásticos (la flor y nata de unos y otros), como dice PAZ con mayor exactitud. Había sido fundada en el Colegio de San Pedrò y San Pablo por el P. Pedro Castini (1587-1663), que la dirigió como prefecto desde 1646 hasta que murió. Castini, italiano de Piacenza que vino a la Nueva España en 1616, había trabajado en las misiones de Sinaloa durante 24 años (BERISTÁIN). Núñez predicó en sus exequias y lo sucedió como prefecto hasta su propia muerte (ZAMBRANO, pp. 521 y 542). Los congregantes eclesiásticos no serían pocos, puesto que una de las obras de Núñez, Tratado quarto del modo y perfección con que se reza el Officio divino y se dize la Missa (1685), fue "compendiado de [sus] pláticas para vso y memoria de NN. PP. Sacerdotes de la Congregación de la Puríssima... [por] el Ldo. Juan de Olivares Toralvo..., actual prefecto de la Puríssima"' (MEDINA). Una tercera parte de las treinta y tantas obras de Núñez se elaboraron así, a base de las pláticas espirituales que cada martes daba Núñez en la capilla de la Purísima (sobre las obligaciones de los congregantes, sobre la confesión y comunión, sobre la oración, sobre la Pasión de Cristo, sobre la devoción a las Ánimas del Purgatorio o al Espíritu Santo, etc.), "compendiadas" y editadas por un secretario que se llamaba "prefecto actual" (Núñez era "el Padre Prefecto").

${ }^{24}$ Citado por A. CaStro Leal, Juan Ruiz de Alarcón, México, 1943, p. 25, del libro de Francisco XARQUE, Vida prodigiosa en lo vario de los sucesos, exemplar en lo heroico de religiosas virtudes, admirable en lo apostólico de sus empleos, del V. P. Antonio Ruiz de Montoya (Zaragoza, 1662). En el mundo hispano-católico de la época se imprimieron centenares de libros con títulos parecidos. (¿Habrá alguien capaz de leer y estudiar toda esta literatura hagiográfica?).

${ }^{25}$ NATHANAEL SOTUELlUS (Nathaniel Bacon, alias Southwell), Bibliotheca scriptorum Societatis Iesu, Romae, 1676 (segunda continuación del Catalogus del 
la ciudad de México, por virtuoso y sabio, veneración de todos". Sesenta y cinco años después de su muerte, esa fama persistía en la memoria: "[El P. Núñez fue] sugeto por muchos títulos excelente, y de los primeros hombres de su siglo, tan universalmente docto en toda especie de facultades y ciencias, que lo juzgaba la fama común por digno de asistir a un Concilio General ${ }^{26}$. Escucháronse sus sentencias por oráculos, y fue tan santo, que se veneraron algunos de sus dichos por prophecías'"27.

Dos pequeñas anécdotas, situadas las dos en los comienzos de la carrera de Núñez, dan idea de lo que fue su influencia, y del respeto que lo rodeaba. Una vez el virrey Conde de Baños, que se confesaba con Núñez,

había ido... por algunos días al santuario de los Remedios, más de tres leguas distante de la ciudad de México, y estando en la mesa cerca de las dos de la tarde se acordó que era martes, y al punto mandó poner el coche para asistir a la Congregación de la Purísima... Por mucha prisa que se dieron los cocheros, llegó cuando ya el Padre Prefecto estaba haciendo la acostumbrada plática. Por no interrumpirle ni inquietar el devoto concurso, quiso quedarse

P. Rivadeneira), p. 79. Sotuelo menciona a Núñez como autor del libro intitulado Día bueno y entero, con todas sus obras, reglas y obligaciones, de vn congregante de la Puríssima (México, 1667); pero, a semejanza de los bibliógrafos que lo precedieron, traduce el título al latín: Dies rectus, quo quicquid bonus sodalis quotidie agere debeat, continetur. (Nicolás Antonio, a su vez, retradujo Dies rectus como El día derecho). EUGENIO DE URIARTE, Catálogo razonado de obras anónimas y seudónimas de autores de la Compañía..., t. 4, Madrid, 1914, núm. 5835, desconocedor del Día bueno y entero, creía que el Dies rectus era la misma cosa que el Compendio de las obligaciones... (infra, p. 639, nota 80). - Por cierto que Núñez, cuando le mostraron el elogio de Sotuelo - ¿en 1677?-, "dio gran testimonio de su humildad", pues luego incontinenti requirió la pluma y escribió al margen de la página: "Este P. Antonio Núñez fue el hermano mayor de los locos del Hospital de San Hipólito". Téngase en cuenta que Núñez veló mucho por este hospital de los locos: "Viendo lo que padecían, les procuró una renta de 15,000 pesos para la cena diaria, y otra de 3,000 pesos para el desayuno, que ofreció liberalmente el capitán D. Juan de Chavarría Valera"' (ZAMBRANO, p. 537).

${ }^{26}$ Años después dirá BERISTÁIN: "Fue tanta su erudición en las ciencias sagradas y profanas..., que era sentencia común que si hubiera de celebrarse Concilio General, debería ir el P. Núñez por Toólogo y Letrado de la N[ueva] E[spaña]".

${ }^{27}$ F. X. LAZCANO, Vida de Oviedo (mencionada supra, p. 595, nota 10), p. 45. "Murió - añade Lazcano- con aclamación de Bienaventurado, y a un ecclesiástico de espíritu elevado se le manifestó su pobre lecho, al tiempo de agonizar, rodeado de Ángeles, y se le dio a entender que de la cama havía volado su alma dichosíssima a la gloria'. 
junto a la puerta y sentarse en una de las últimas bancas, y lo hubiera hecho si el padre, con una cortesana violencia, no le hubiera obligado a subir a la silla que siempre le tenía preparada conforme a su carácter ${ }^{28}$.

La otra anécdota se refiere con toda probabilidad al mismo Conde de Baños (Oviedo, discretamente, calla esta vez el nombre):

Un señor virrey lo llamó para consultarle un caso bien difícil. Respondióle el Padre lo que le pareció que según Dios se debia hacer. [Y, como el virrey no se mostraba muy convencido], le dijo con toda resolución: "Vuestra Excelencia haga lo que le pareciere, pero yo bien sé que esto es lo que debe hacer, y de no hacerlo se irá sin remedio al infierno sin pasar por el purgatorio" [!]. El virrey mudó de parecer, haciendo al pie de la letra cuanto el P. Antonio le había aconsejado; y decía que era notable el miedo que le tenía.

La Carta de Sor Juana, que abunda en reconocimientos de los méritos del jesuita - su ciencia, su santidad, su discreción, etc.y en expresiones de gran afecto a su persona, no contiene una sola expresión de miedo.

Para apreciar plenamente la fuerza de la recién descubierta Carta de Sor Juana es, además, muy útil conocer las ideas de Núñez acerca de "la monja ideal". Su carrera de director espiritual de monjas se traba, desde luego, con su reputación de varón santo y discreto, ya firmemente establecida cuando, en 1663, sucedió al P. Castini como prefecto de la Purísima. Probablemente lo pri-

${ }^{28}$ ZAMBRANO, p. 521 (cf. también pp. 522 y 536). O sea que Núñez obligó al virrey, con violencia - aunque sin grosería-, a causar el alboroto que él quería evitar (como esos profesores que se dan maña para poner en vergüenza al alumno que llega tarde). Núñez era hombre de temperamento enérgico y dominante (cf. infra, p. 638, nota 79). También obligó a su amigo Isidro Sariñana a ser obispo de Antequera-Oaxaca. Cuando le llegó el nombramiento, en abril de 1683, Sariñana habló con Núñez, y Núñez le dijo que lo aceptara. "Dictamen fue éste a que pudo el doctor Sariñana inclinar la cabeza desde luego y obedecer ciegamente, oyéndolo de unos labios por donde no ignoraba se destilaba mirra muy escogida de discreción, ciencia y espíritu". En realidad no pudo. Durante meses anduvo corroído de dudas y asediando a Núñez, hasta que éste, un día, "le dijo con alguna seriedad: "Ya le tengo dicho... lo que ha de hacer, y así no tiene que volver acá [a casa de los jesuitas], que necesito para otras cosas el tiempo", y con esto le despidió, sin quererle dar más oídos". Cuando por fin, en agosto del año siguiente, se llevó a cabo la consagración episcopal, Núñez tuvo que colocarse materialmente junto a Sariñana para darle ánimos, pues todavía daba señales de querer echarse atrás. Sobre este episodio véase ZAMBRANO, pp. 528-529. 
mero que hizo cuando comenzó a tener hijas espirituales fue darles a leer cierto manual escrito en 1599 por el P. Antonio Arias, uno de los primeros jesuitas venidos de España: BERISTÁIN, en la noticia que dedica a este $P$. Arias, pone entre sus obras $L a$ perfecta religiosa, "tratado ascético compuesto para una hermana del Autor, religiosa en España”, y añade que "el P. Antonio Núñez lo propagó entre las monjas de Mégico". En todo caso, ya en 1665 publicó Núñez el primero de sus escritos "monjiles"': Pías consideraciones y afectiva meditación de los daños que pueden ocasionar las dependencias de señoras religiosas que vulgarmente llaman devociones. Este librito de 28 hojas no se conoce sino por la descripción de MEDINA (núm. 940). En la portada se dice que las Consideraciones han sido "sacadas por la mayor parte de las obras de Santa Theresa", y que quien las recogió y dispuso " a devoción y obsequio de las señoras religiosas, esposas de Christo Nuestro Señor" , fue “"un sacerdote de la Congregación de la Puríssima ${ }^{29}$, fundada con authoridad apostólica en el Colegio Máximo de S. Pedro y S. Pablo de la Compañía de Jesús de México'. Ningún moderno, que yo sepa, ha leído estas Pías consideraciones. (Cf. infra, p. 612, nota 44). Del mismo año de 1665 parece ser también una edición de los Ejercicios de San Ignacio adaptados para monjas ${ }^{30}$.

${ }^{29}$ En obras posteriores, Núñez no se llamará "un sacerdote", sino "el Prefecto". Se trata, con toda seguridad, del librito que BERISTÁIN, sistemático abreviador y alterador de títulos, llama (s.v. "Núñez de Miranda") Advertencias a las religiosas sobre las devociones, dando como fecha 1685 . Si esto no es error por " 1665 ", se tratará de una reedición que los bibliógrafos modernos aún no han descrito. (No pocas obras de Núñez tuvieron reediciones, algunas de ellas hasta bien entrado el siglo XIX).

${ }^{30}$ El caso de los Ejercicios es aún más nebuloso que el de las Pías consideraciones. BERISTÁIN pone en 1665 unos Exercicios espirituales de San Ignacio con notas y advertencias oportunas, y en 1695 unos Exercicios de San Ignacio adaptados a las religiosas, esposas de Jesucristo. Sólo este libro de 1695 ha sido descrito modernamente: Exercicios espirituales de Sn. Ignacio acomodados a el estado y professión religiosa de las señoras virgenes, esposas de Christo, instruido con un Diario breve, pero suficiente, de todos los exercicios cotidianos, para que se empiezen a exercitar, dispuesto por el P. Prefecto de la Congregación de la Puríssima... Dedicados a las mismas señoras religiosas vírgenes, esposas de Christo (196 pp). El nombre de Núñez aparece en la censura y en la licencia del provincial. No se trata, a todas luces, de una $1^{\text {a }}$ edición, pues Núñez murió a comienzos de 1695, y hacía tiempo que estaba casi ciego. Quizá los Exercicios de 1665, "con notas y advertencias oportunas", sean la $1^{\text {a }}$ edición. "La primera edición mexicana de los Ejercicios es de 1695", declara G. DECORME, La obra de los jesuitas mexicanos durante la época colonial, México, 1941, t. 1, p. 295: se olvida de esa muy probable edición de 1665, como también de otra de 1690 (MEDINA, núm. 1472), conocida sólo por un ejemplar falto de portada, de modo que puede especularse si será 
Catorce años después, con mayor experiencia en cuanto confesor y en cuanto escritor, Núñez se dirige a las monjas con voz propia (ya no sólo con la del P. Arias, Santa Teresa y San Ignacio). En 1679, en efecto, se imprimió la Plática doctrinal que hizo el Padre Antonio Núñez... en la professión de vna señora religiosa del convento de San Lorenço"s, editada por "el Br. Diego del C̣astillo Marques, prefecto actual de la Congregación de la Puríssima, que la saca a luz en obsequio de las señoras religiosas', dedicándosela a D. Francisco de Aguiar y Seixas, a la sazón obispo de Michoacán ${ }^{32}$. La Plática doctinal sí ha tenido lectores modernos, lo mismo que estas otras dos obras "monjiles" de Núñez:

Cartilla de la doctrina religiosa, dispuesta por vno de la Compañía de Jesús para dos niñas, hijas espirituales suyas, que se crian para monjas ${ }^{33}$ y desean serlo con toda perfección. Sácala a luz, en obsequio de las llamadas a religión, y para alibio de las maestras que las instruyen, el Lic. Francisco de Salzedo, primer capellán de las señoras religiosas de Santa Theresa... y prefecto [actual] de la Puríssima. Dedicada a las mismas dos niñas para cuyo provecho y dirección principalmente se dispuso. México, $1680^{34}$.

o no una edición más de lo mismo (el ejemplar sin portada tiene 44 folios). BÉNASSY pone en su Bibliographie los Exercicios de 1695 y dice que hay ejemplar en Les Fontaines, Chantilly (signatura W 134), pero en el cuerpo del libro no nos dice en qué consiste la tarea de "adaptación" o "acomodación" de Núñez. "Un ejemplar vi en 1948 en la biblioteca de Ntra. Sra. de los Ángeles", dice ZAMBRANO (sin aclarar dónde está esa biblioteca).

${ }^{31}$ Núñez había tenido un papel muy importante en la construcción de este convento. Véase GHÁVEZ1 ${ }^{1}$, p. 383.

32 Descripción de Medina (núm. 1189). En el vo de la portada está la dedicatoria a "D. Francisco Seixas de Aguiar y Vlloa"; siguen "hojas 2-17 de texto, a dos cols., y en el v. de la última la "Distribución del tiempo y exercicios del día, que se han de acomodar y ceder a los de la comunidad"'. Como la "segunda impressión", de 1710 (descrita también por MEDINA), tiene 31 fols. además de la portada, es posible que la "Distribución del tiempo..." empiece en el fol. $17 \mathrm{v}^{\circ}$ de la $1^{2}$ ed., pero que no sea éste el final (las reediciones solían reproducir a plana y renglón la edición en que se basaban). El P. Aureliano Tapia, descubridor de la Carta de Sor Juana, me ha facilitado copia (modernizada) de algunos pasajes que se encuentran en los primeros folios de la Plática doctrinal, ed. de 1679 (aprovecharé estas citas más adelante). A. PALAU, Manual del librero, registra otra reedición de 1830, impresa por Alejandro Valdés (24 pp.). Cf. infra, nota 36.

33 BERISTÁIN, que sólo menciona la reedición de 1696 - s.v. "Estrada, P. Sebastián", a quien atribuye la obra-, humaniza un poco esa monstruosidad de las niñas que "se crían para monjas", pues abrevia así el título: Cartilla de la doctrina religiosa para las niñas que desean ser monjas.

${ }^{34}$ Esta $1^{a}$ edición figura, anónima, en MEDINA, núm. 1200. También en la reedición de 1696 el autor es "uno de la Compañía". El nombre de Núñez 
Distribución de las obras ordinarias y extraordinarias del día para hazerlas conformes al estado de las señoras religiosas... Dispuesta por el R. P. M. Antonio Núñez..., prefecto que fue de la Illustre Congregación de la Puríssima. México, 1712. Esta edición póstuma es la única que se conoce ${ }^{35}$. La primera bien pudo ser contemporánea de la Plática doctrinal (1679) y de la Cartilla (1680).

También es póstumo un librito cuya portada, en la $1^{\text {a }}$ edición conocida, reza así: Testamento mystico de vna alma religiosa que, agonizante de amor por su Divino Esposo, moribunda ya, para morir al mundo, instituye a su Querido voluntario heredero de todos sus bienes. Dispuesto por el M. R. P. Antonio Núñez, prefecto que fue de la Congregación de la Puríssima. México, 1707. Ningún moderno parece haber leído este librito de 13 hojas, a pesar de que tuvo varias ediciones. Como el testamento "místico" se refiere obviamente al acto de la profesión religiosa, por el cual la monja queda en efecto muerta al mundo, podría conjeturarse que se trata de un extracto de la mencionada Plática doctrinal en la profesión de una religiosa de San Lorenzo ${ }^{36}$.

aparece en las reediciones de $1708,1750,1766$ y 1831 . PALAU, op. cit., añade una edición de 1698 (¿errata por 1696?), y BÉNASSY, p. 46, nota 32, otra de 1760 (¿errata por 1766?). El P. URIARTE (citado por ZAMBRANO) llamó la atención sobre otro libro anónimo de 1693, Práctica de las estaciones de los Viernes como las andaba la V. M. María de la Antigua, seguin se ha podido colegir y sacar de su libro, en cuya portada se advierte que ha sido "copiada, a la letra, de una instrucción muy santa que un religioso de la Compañía de Jesús dispuso para dos niñas hijas espirituales suyas". Está por ver qué relación guardan la Cartilla y esta Práctica de las estaciones. También está por averiguar si la Tabla abecedaria de doctrinas religiosas (1708) que menciona BERISTÁIN no será lo mismo que la Cartilla. La bibliografía de Núñez está llena de misterios no aclarados. -Por cierto, Sor Juana cita dos veces a la Madre María de la Antigua: en la Respuesta, 1147, y en los Ejercicios de la Encarnación (SJ, t. 4, p. 494).

${ }^{35}$ Descrita por MedinA, núm. 2335. Probablemente es lo que BERISTÁIN llama Máximas sustanciales de la vida regular y espiritual, diciendo que se imprimió en 1712. Habría que ver qué relación existe entre la Distribución de las obras ordinarias y extraordinarias del día, libro de tamaño considerable (160 pp.), y la "Distribución del tiempo y exercicios del día" que figura como apéndice de la Plática doctrinal de 1679 (cf. supra, nota 32). Hay que pensar también en el "Diario breve de todos los exercicios cotidianos" incluido en la edición "monjil" de los Ejercicios (supra, nota 30). Núñez, según lo presenta su biógrafo, era extremadamente escrupuloso en cuanto a la distribución de su propio tiempo. Por lo demás, "todo lo que dijo y todo lo que escribió se refiere a cuestiones prácticas: qué hacer y cómo proceder en este o en aquel caso" (PAZ, p. 589). Chávez, como ya dije, transcribe no pocos pasajes de la Distribución de las obras del día. De sus dos libros (sobre todo CHÁVEz ${ }^{1}$, pp. 167-175) proceden las citas que haré más adelante.

36 "De la entrada de una religiosa - dice la Plática doctrinal de Núñez- 
A esta bibliografía "monjil" de Núñez ha agregado la profesora Bénassy-Berling un título más: Destierro de ignorancias. Fragmento áureo, precio[si] ssimo, de la juiciosa erudición moral del doctíssimo y religiosíssimo $P$. M. Fr. Raymundo Lumbier... Dalo a la estampa, por orden y con mandato de su Ilustríssima el Señor Arçobispo, en obsequio de las señoras religiosas, alibio de sus PP. Capellanes y consuelo de todos sus Confessores, el Padre Prefecto de la Puríssima, y Su Illma concede 40 días de indulgencia a qualquiera persona... por cada vez que leyere algún párrapho déstos. México, 1694; hojas preliminares y 44 pp. ${ }^{37}$

La profesora Bénassy, que concede no poca atención a este Destierro de ignorancias, dice que el arzobispo Aguiar y Seixas y el P. Núñez se lo "encargaron" a "un religieux nommé Raymundo

comúnmente se dice que se sepulta viva entre cuatro paredes". Esa expresión "común" es la verdad pura. Cuando una novicia profesa, sus compañeras la llevan en procesión hasta el altar, cantando la Letanía de los Agonizantes, cada una con su vela en la mano, "como si la acompañaran de entierro". En ese momento ve la novicia realizado su anhelo de morir. Durante el año de noviciado ha estado "como agonizando con las ansias de dejar el mundo". Estas expresiones pueden haber inspirado el título del Testamento mystico. En vísperas de su profesión, las monjas hacían un testamento "material" en que se despedían - de manera más bien simbólica, a decir verdad - de sus posesiones mundanas (el testamento de Sor Juana es bien conocido). El testamento "místico" abarca mucho más: por los votos de pobreza, castidad y obediencia (a los que se añadía uno más: el de clausura), la monja renunciaba a su propia persona. - Hay, por lo demás, un caso conocido de cambio de título en una obra de Núñez: sus Sumarias meditaciones sobre la devoción a las Ánimas del Purgatorio (1676), que tuvieron varias reediciones, aparecieron en 1872 (sic: ¡ 1872!) con un título más "expresivo": Alma cristiana, no olvides a los difuntos. Meditaciones por el P. M. Antonio Núñez (URIARTE, citado por ZaMBraNO). -Si el Testamento mystico es en efecto un extracto de la Plática doctrinal, hay que observar que ésta se reimprimió, sin cambio de título, por lo menos una vez más (en 1710). Pero es curioso que PALAU registre una edición del Testamento mystico con el mismo año (1830), el mismo impresor y el mismo número de páginas que la mencionada reedición de la Plática doctrinal (supra, nota 32). BÉNASSY, p. 227, nota 47, cita entero el título del Testamento mystico con base en Sommervogel, $\mathrm{y}$, burlándose un poco de J. M. GALLEGOS ROCAFUll (Pensamiento mexicano en los siglos XVI y XVII, México, 1951), que llama "autor místico" a Núñez, observa con mucha razón: "Il serait surprenant que ce titre recouvrît un véritable traité de mystique". Además de la edición de 1830 que acabo de mencionar, y otra dudosa de 1701 , se conocen una de 1731 y otra sin fecha, "aunque de los primeros años de la segunda mitad del siglo XVIII, según parece" (MEDINA).

37 Descripción de MEDiNA, el cual observa que, siendo siete los párrafos en que se divide el librito, el lector puede ganar hasta 280 días de indulgencia. También BÉNASSY se sonríe (p. 46, nota 33): "Les jours d'indulgence ont évidemment pour but d'augmenter le nombre des lecteurs!" 
Lumbier' (p. 48); más aún: "ils ont inspiré ensemble"' el tal libro (lo cual constituye "la preuve qu'ils étaient bons amis"); añade que el libro se destinó "à l'usage des couvents" y que su "but avoué" es "la réforme des trop mondains couvents de Mexico" (p. 174). Desgraciadamente, ninguna de estas afirmaciones tiene base. Lo que ocurre, al parecer, es que la hispanista francesa sintió que una obra así debía tener algún papel en la historia de la "conversión" de Sor Juana, y esta tentadora posibilidad la llevó incluso a suponer que fue en 1692 cuando el arzobispo y el jesuita se pusieron de acuerdo e "inspiraron" el Destierro de ignorancias, publicado - dice ella - "un peu plus d'un an après la Respuesta, et deux ans avant la conversion", cuando es obvio que la publicación se hizo un año después de esa "conversión" "38. La verdadera historia del libro está contada en su portada. Destierro de ignorancias es el título que se puso a un fragmento tomado de una obra muy erudita del doctísimo Lumbier, fragmento juzgado de tal valor por el arzobispo, que dio "orden y mandato" de que se publicara, encargando del asunto al prefecto de la Purísima ${ }^{39}$. Es claro que ese "fragmento áureo, preciosíssimo" procede de los oceánicos Fragmentos morales (Zaragoza, 1680-1683) de fray Raymundo Lumbier, carmelita navarro establecido en Zaragoza, donde

38 BÉNASSY comete un extraño error en cuanto a la fecha de la "conversión". CALLEJa dice con todas sus letras que ésta ocurrió "el año de mil seiscientos y noventa y tres"'. Ella, después de decir (p. 166) que Sor Juana escribió su Respuesta a Sor Filotea (marzo de 1691) "deux ans avant sa conversion" -y, en efecto, nada se opone a imaginar que ello ocurrió en marzo de 1693-, habla sistemáticamente de "la crise dramatique de l'année 1694" (p. 170), "l'inexplicable renonciation de 1694" (p. 172), "la conversion de 1694" (pp. 186 y 228), "la crise de 1694" (p. 220), y dice que Núñez, según Oviedo, "fut absolument stupéfait de se voir rappeler par sa pénitente en 1694" (pp. 175-176), cuando lo que OVIEDO afirma es que "la admirable mudanza de la Madre Juana" sucedió "dos años antes de su muerte", o sea, leído literalmente, en abril de 1693. - Ningún bibliógrafo cita más edición del Destierro de ignorancias que esa de 1694 (posterior a la "conversión" de Sor Juana), y no se ve por qué BÉNASSY la declara "2da. ed." (p. 46, nota 33: "Nous n'avons pas pu trouver l'exemplaire [sic] de la première édition et ignorons sa date"), salvo, quizá, para poder incluir en el dossier de la "conversión" un documento tan "peu connu", o sea por un parti-pris inconsciente.

${ }^{39}$ Quizá Núñez, pero quizá no. Núñez murió en febrero del año siguiente, y hacía tiempo que estaba un tanto "fuera de circulación". El encargado de la publicación de libros en la Purísima era el "prefecto actual" (cf. supra, p. 602, nota 23), llamado a veces "prefecto" a secas (por ejemplo en la Concordancia espiritual de las siete missas del Espiritu Santo [¿de Núñez?], publicada en 1682 "a devoción del Dr. Alonso Alberto de Velasco, prefecto de la Congregación de la Puríssima". 
publicó entre 1672 y 1683 , además de algunas obritas piadosas, no pocos tratados "técnicos" de teología. Los Fragmentos morales se presentan como "prosecución de los que están en la Suma de Arana", lo cual nos transporta a una zona bibliográfica apenas pisada en nuestros días: la literatura, en latín o en español, destinada a ilustrar a los ministros de la religión en toda clase de cuestiones de teología moral ${ }^{40}$. El fragmento que tan deslumbrado dejó a Aguiar y Seixas se refiere al ministerio de los confesores de monjas. Así como la Cartilla de 1680 se publicó para alibio de las maestras de novicias, así el fragmento áureo de Lumbier se publica para alibio de los capellanes y confesores de conventos femeninos (y, naturalmente, ambas publicaciones redundan en obsequio de las señoras religiosas). Bien podemos imaginar que el arzobispo, rendido admirador del doctísimo y religiosísimo carmelita ${ }^{41}$, creyó

${ }^{40}$ El título de "la Suma de Arana" (fray Juan Anastasio de Arana, carmelita como Lumbier) es en realidad Súmulas de moral, y su autor "primitivo" no es Arana, sino el dominico fray Simón de Salazar. Arana fue un adicionador, pero muy importante; y Lumbier se inició como adicionador del adicionador: la edición de 1676 de las Súmulas de moral se complementa ya con "vnos fragmentos recogidos y ajustados" por él, hors d'oeuvre de sus futuros Fragmentos morales (t. 1, 1680; t. 2, 1683; en total, 1216 páginas de numeración corrida). Los Fragmentos morales se editaron una sola vez. Las Súmulas de moral, en cambio, continuaron reeditándose, aunque sin la enorme frecuencia con que se reeditó, hasta bien entrado el siglo XVIII, otro libro de fray Simón de Salazar: su Prontuario de confesores $\left(1^{\mathrm{a}}\right.$ ed., 1659), manual en que los curas consultaban si tal cosa era o no pecado, si el pecado era venial o mortal, si el mortal era grave o no tan grave, etc. El número relativamente exiguo de ediciones de las Súmulas de moral se explica por su carácter más teórico y más especializado: no se dirigen al cura de misa y olla (a ése le basta el Prontuario), sino a quienes preparan, ya sea su examen obligatorio de teología moral antes de ordenarse, ya exámenes especiales para obtener alguna prebenda o para recibir un título de "confessor". (Los Fragmentos morales de Lumbier están, evidentemente, en la línea de las Súmulas, no en la del Prontuario; son una obra de carácter doctrinal).

${ }^{41}$ Diez años antes, en 1684, cuando Aguiar y Seixas acababa de sentarse en el trono arzobispal de México, había mandado imprimir otra obra de Lumbier, Noticia de las sesenta y cinco proposiciones condenadas por $N$. SS. P. Inocencio $X I$ mediante su decreto de 2 de mayo del año 1679 ( $1^{\text {a }}$ ed., Zaragoza, 1680). La ed. de México se dice "séptima impressión" y reproduce, con licencias y todo, la $6^{\mathrm{a}}$, de Zaragoza, 1683 (aunque ya había habido otra $7^{\mathrm{a}}$ ed. en Lisboa, 1683). Es de suponer que Aguiar y Seixas tampoco añadió nada al fragmento áureo impreso por su orden en 1694, sino que lo reprodujo tal como estaba en alguno de los dos tomos de Lumbier (y en este sentido sí puede decirse que hizo una " ${ }^{a}$ ed."). BÉNASSY, p. 46, nota 33 , hace una observación interesante: "Il est dit et répété en gros caractères que les idées contenues dans ce livre [el Destierro de ignorancias] sont celles de l'archevêque". Como las "ideas" son obviamente las del autor, o sea del respetadísimo Lumbier, ello querrá decir tal vez que 
oportuno plantar una buena semilla de instrucción para los muchos presentes y futuros confesores de monjas (quizá, sobre todo, en vista de que Núñez, muy viejo, podía morir de un día para otro).

Así, pues, el Destierro de ignorancias no nos dice nada específico acerca de los conventos de México. Sin embargo, las noticias que se nos dan son interesantes como materia de comparación ${ }^{42}$. El tono del autor - nos dice BÉNASSY - es colérico y furibundo al reprobar ciertos abusos ("ce qui prouve qu'ils existaient"), como el lujo en la vestimenta, los juegos de apuestas, y sobre todo, sobre todo, la horrenda e inveterada plaga de los "devotos de monjas". El primer abuso existía en todo el orbe hispano-católico (piénsese en los retratos de Sor Juana, y en los de tantas monjas de todas partes), pero los otros dos parecen haber sido más frecuentes en España, en particular el de los "devotos" 43 . El texto que reproduce Bénassy sobre este punto no se refiere, por cierto, a los confesores de monjas, sino a los confesores de seglares devotos de monjas: "Respondo que si la devoción fuesse tal que mediassen frequentes visitas o repetidos papeles de amores (mucho más si hubiesse otras demonstraciones externas sensuales), estarían en pecado mortal y no deberían ser absueltos si después de amonestados una y otra vez no se enmendassen". Y comenta ella: "La force des habitudes, le peu d'espoir qu'ont les autorités d'être obéies sont très bien démontrés par le ton furibond du Destierro" (Lumbier llega a plantear casos de posible excomunión).

En cambio, las obras mencionadas de Núñez están dirigidas a las monjas. A ellas les sería no sólo inútil, sino dañoso, hacerse casuistas en materia de relaciones con "devotos": "Vosotras, hijas mías, no os metáis ni aun en saber si son pecado", les dice en la Cartilla (p. 11). Básteles saber que cualquier desliz en ese delicado terreno está mal, y punto. Por el voto de castidad, les dice en la

al arzobispo le importaba dejar muy claro que la decisión de publicar el librito era suya (y no, por ejemplo, del P. Antonio Núñez o del prefecto "actual" de la Purísima).

42 "Lumbier admet que la clôture est très bien respectée; peut-être plus complètement qu'en Espagne", dice BÉNASSY, p. 47. Habrá que leer: "Lumbier reconoce que en los conventos españoles se observa bien la clausura". El Destierro de ignorancias "ne contient pas la moindre allusion aux activités personnelles de Sor Juana" (p. 174). Por supuesto: ¿qué informes podía tener el carmelita de Zaragoza sobre la jerónima de México?

43 No es que en México no los hubiera. En el Diario de Robles se lee: "5 de enero de 1682. Notificación a las monjas de la Concepción y San Jerónimo no tengan ni consientan devotos en las rejas y porterías". Lo que falta en la Nueva España es la frondosa producción satírica que sobre el tema hubo en España (Quevedo, por ejemplo). 
Plática doctrinal, han renunciado a todo trato con el mundo. Allí no hay distingos:

Una esposa de Cristo, el día que profesa..., ha de quedar con su amor tan muerta al mundo, cosas, fueros y personas humanas como si nunca los hubiera visto, ni sido en el mundo... Como un muerto no gusta ni echa menos cosas de esta vida... ni tiene trato humano, ni visita ni es visitado..., así una esposa de Cristo ha de quedar muerta al mundo y todos sus fueros..., todas sus conjunciones, visitas, dones $y$ dependencias ${ }^{44}$.

En cuanto al voto de pobreza, sí hay algunos distingos. La monja que "da, recibe, presta o dispone cosa que llegue o exceda el valor de un peso" comete pecado grave, - salvo que tenga "licencia bastante, general o particular, del superior" 45 ; el pecado es venial "si la materia es leve, como de uno o dos reales"; no es pecado, pero sí imperfección, "tener, aunque con licencia, alhajas curiosas, preciosas o excusables'. Claro que la religiosa ideal debe evitar hasta las imperfecciones, y "gustar que todas sus cosas y alhajas sean pobres y ordinarias..., preciarse y alegrarse de ser y parecer pobre en todo y por todo: en la persona, celda, criada [!], alhajas, vestuario, comida, bebida, etc.", y "no quedar en nada suya, ni aun en el albedrío". También hay grados de perfección en cuanto al voto de obediencia: obedecer "al pie de la letra" y "con ejecución pronta y perfecta", pero sólo "exteriormente", no es sino "el primero e ínfimo grado de obediencia"; los grados superiores consisten en obedecer con el entendimiento ("teniendo por bueno y mejor cuanto la prelada o superior ordena, creyéndolo así firmemente aunque más repugne y replique nuestro amor propio, procediendo con obediencia ciega") y con la voluntad ("amando y queriendo lo que nos mandan'). Es ésta la materia en que más insiste Núñez:

44 Las Pías consideraciones de 1665 contra "las dependencias que vulgarmente llaman devociones" se refieren muy probablemente a esta materia, aunque es algo difícil imaginar cómo pudo Santa Teresa suministrar materia para "la mayor parte" de sus 28 folios.

45 Las monjas dependían canónicamente de la prelada o priora (y en segunda instancia del arzobispo, no de una "superiora general" de la orden). Pero Núñez no sólo dice "la prelada", sino también "el superior", "la prelada o superior", "los prelados", “los mayores”. Así se introducen calladamente los directores espirituales. - En tiempos de Carlos V, unas monjas asuncionistas de Almagro se habían puesto a hacer alquimia, y las autoridades eclesiásticas lo prohibieron: la alquimia "es illícita, quanto más a una monja, que por ser de servil condiçión no puede gastar ni tener nada sin liçençia de su mayor' (Visita y reformación del convento de la Asunción, 1546, cit. por F. Rodríguez Marín, ed. del Quijote, 1947-1949, t. 5, p. 29). 
"Por el voto de obediencia, la religiosa renuncia a su propia voluntad y libre albedrío". La obediencia es la piedra de toque de las demás virtudes: si una monja brilla por su "penitencia, mortificación, oración, éxtasis y revelaciones" pero no es obediente, todas esas maravillas "no sólo se hacen sospechosas, sino ruinosas, todas se condenan por diabólicas". Y, como para aplastar cualquier tentación de desobediencia, viene la amenaza: "Parece siente Dios más las faltas de obediencia a los prelados, por las malas consecuencias, que las que se hacen a su misma Persona"'. En efecto, "consta de la Escritura e historias eclesiásticas" que Dios "ha hecho más severos castigos en los que faltan al debido respeto de sus mayores que aun en los que quebrantan su Ley" (fols. 4-5).

En la Distribución de las obras del día Núñez les da a leer a las monjas un cántico en alabanza del director espiritual (p. 53):

La luz del confesor es la luz del cielo... La tierra se mide y vende a caballerías, el agua a surcos, el aire a tiempos [?] y el fuego a brasas..., pero los rayos del sol y celeste influjo de las estrellas, ¿quién fue tan temerariamente necio que quisiese distribuirlo por su tasa?... Así ha de lucir y alumbrar el padre espiritual y confesor como el sol y astro celeste, que no guía, mide ni tasa ni dispensa por respetos humanos ni voluntad criada, sino por la divina únicamente.

El confesor es "como único norte del alma" de las monjas. ¿Por qué? "Porque Dios lo quiere y es su voluntad y gusto". El confesor es quien "conduce al bien de las almas y aumento espiritual del convento" (no precisamente la prelada). Consecuencia: "Cada una debe tener su confesor y padre espiritual señalado, a quien tenga dada su conciencia..., sin recurrir a otro... El confesor y padre espiritual ha de ser uno, único, invariable..., conservado con inviolable constancia, consultado, creído y seguido como celeste oráculo, sin recurrir a otro para el gobierno de su alma"' (pp. 54-55).

También es de interés el largo pasaje de la Distribución de las obras (pp. 36-37) en que Núñez expone límpidamente su opinión acerca de las actividades intelectuales y artísticas de las monjas:

Deseo mucho, para alivio y decoro de vuestro convento y estimación de vuestras personas, que os aventajéis en todas buenas prendas, desde las primeras ínfimas hasta las últimas supremas; que leáis ventajosamente el romance y latín; que labréis y bordéis con todo aseo; que aprendáis perfectamente música y, si el Señor os diere voz, cantéis y toquéis todos los géneros de instrumentos que pudiereis... y, finalmente, adquiráis todas las buenas obras y talentos que podáis. 
¿Y para qué, si pensáis? ¿Para usarlas de ostentación o logros de empeño? De ninguna manera: para que las tengáis guardadas y apañadas, y sólo las saquéis y uséis cuando y como el convento las hubiere menester.

Núñez es terminante: todo ha de quedar intramuros; nada ha de trascender. Si una monja quiere aprender latín, que lo haga, pero sólo "para rezar con inteligencia" 46 . Si otra quiere dedicarse a la música, que lo haga, pero sólo "para alabar a Dios en el Coro" durante los Oficios, y para "servir al convento en su ejercicio" (es deseable que cada convento tenga una organista competente). Es bueno que haya monjas eminentes en algún talento, pero "en igual y superior grado de eminencia" deben poseer el talento máximo: vencer la tentación "de lucir y ostentarse". Monja que se luce - no ya ante la gente del mundo, sino ante sus compañeras mismas-, monja que anda mal. Aquí el yo del jesuita resuena poderosamente: "Muy sobresalientes quiero yo vuestras prendas, pero no quiero yo que sobresalgáis con ellas... [de tal modo] que asombréis a las otras o les quitéis su lugar" (asombrar a las otras es hacerles sombra, eclipsarlas). Para dejar mejor grabado su pensamiento, Núñez lo expresa en una aleluya endecasílaba:

Guárdate de ostentar en tu convento más gracia y más favor y más talento,

y luego en majestuoso lenguaje bíblico: "Habéis de criar y engrosar y regalar las pingües reses de vuestros talentos y prendas, para degollarlas con el cuchillo de la Mortificación ${ }^{47}$, en aras de la Caridad, en el templo de la Obediencia. Esto es sacrificar a Dios vuestras gracias; lo otro, ofrecer al ídolo de la Vanidad los talentos".

$46 \mathrm{El}$ rezo de las horas (desde maitines hasta completas), obligatorio para las monjas, se hacía en latín. Naturalmente, casi todas rezaban como pericos. Sor Juana, en su Carta, agradece a Núñez el haberle pagado maestro de latín en las semanas que precedieron a su entrada en el convento de carmelitas. Núñez acababa de conocerla, pero "ya tenía noticia de [sus] prendas y dones singulares" (OVIEDO), de manera que sabía que no era dinero tirado a la calle. Cf. infra, pp. 659-662, anotaciones $P$ y $Q$.

47 También CALLEJA emplea lenguaje bíblico al contar cómo Juana resolvió cambiar lo mundano por lo religioso, "y en cada libro que abandonava degollarle a Dios vn Isaac". Calleja se refiere a la entrada en el convento. Seguramente Sor Juana se lo contó así a su amigo en algưna carta. Lo curioso es que el propio Calleja es quien da la noticia de que Sor Juana llegó a reunir en su celda una biblioteca de 4,000 volúmenes (las 4,000 víctimas del sacrificiohecatombe final). 
Finalmente, he aquí lo que siente Núñez (ibid., p. 123) en cuanto a las lecturas:

$\mathrm{Ni}$ por el pensamiento os pase leer comedias, que son la peste de la juventud y landre de la honestidad ${ }^{48}$... No habéis de leer ni tener ni sufrir en vuestra celda libros profanos de comedias, novelas ni otro amatorio alguno, sino todos han de ser sagrados, compuestos y modestos..., [pues] ¿cómo pensará en la Pasión de Cristo, en la pureza de su Madre, en la eternidad de la otra vida, una cabeza llena de locuras de Don Belianís... [!], o las torpes ternuras de Angélica y Medoro..., o las volantes delicias de las fábulas, Venus, Marte, etc.?

Tras todos estos pasajes - la exaltación del padre espiritual, "oráculo" de Dios y "estrella" que rige el destino de las monjas, las severas advertencias contra quienes cambian de confesor (el confesor debe ser uno, único, invariable), la doctrina sobre las actividades intelectuales y artísticas de las religiosas ${ }^{49}$, la condena de quienes se lucen opacando a las demás, el repudio de todo libro profano- se percibe la silueta de Sor Juana. Es lástima no saber cuándo se publicó por primera vez esta Distribución de las obras del día. La condena de las comedias bien puede aludir a Los empeños de una casa, estrenada en octubre de 1683 (y que supone en Sor Juana la lectura de buen número de comedias). Pero no es imposible que la Distribución sea contemporánea de la Cartilla (1680) y de la Plática doctrinal (1679) ${ }^{50}$, obras que Sor Juana tiene que haber leído cuando escribió su Carta. En tal caso, el atrevimiento de la Carta salta aún más a la vista, pues viene a ser una cumplida

48 Las comedias son dañosas también para quienes viven en el mundo. Entre los dichos de Núñez recogidos por OVIEDO está éste: "Congregante de la Purísima que va a la comedia... sepa que no es congregante, ni es para la Purísima, ni tiene que venir a ella".

49 Dije que el Destierro de ignorancias (el "fragmento" de Lumbier publicado en 1694) es útil como materia de comparación. Es interesante, por ejemplo, saber que en ese libro "les activités littéraires, éventuellement profanes, ne sont ni approuvées ni désapprouvées, il n'en est pas question" (BÉNASSY, p. 174). En vista del didáctico afán de exhaustividad de Lumbier, lo que puede concluirse de su silencio es que en la España de 1680 no había monjas que hicieran eso que en 1680 empezó a hacer Sor Juana: composiciones de temas mundanos y aplaudidas en el "siglo". Un moralista tan puntilloso como él se hubiera ocupado del asunto.

50 Recuérdese la "Distribución del tiempo..." publicada en 1679 como apéndice a la Plática doctrinal (supra, notas 32 y 35). Es posible que esta "Distribución del tiempo..." haya sido el embrión de la Distribución de las obras del día, donde pueden haberse añadido pasajes como los aquí citados. 
refutación de la doctrina de Núñez por la vía del silencio. No podía Sor Juana decirle a su confesor: 'He leído esas obritas de V. R., $\mathrm{y}$, la verdad, no me hacen la menor mella'. Prefirió darse por no enterada.

\section{LA CARTA}

El texto que sigue es edición crítica del manuscrito descubierto por don Aureliano Tapia en la biblioteca del Seminario Arquidiocesano de Monterrey y publicado dos veces por él con ortografía modernizada (y con algunos errores de lectura) ${ }^{51}$. Gracias a la gentileza del mismo P. Tapia, he podido consultar directamente el manuscrito. La copia de la Carta de Sor Juana ocupa los fols. 161r-163v de un volumen misceláneo intitulado Varios ynformes, que perteneció seguramente a la biblioteca del arzobispo Francisco Plancarte y Navarrete ${ }^{52}$, y que contiene, entre otras cosas, una Relación impresa en 1702 y manuscritos fechados en 1704 y en 1707. "Es raro - dice PAZ, p. 633- que el copista haya omitido la fecha" de la Carta. Seguramente no la tenía el original. Pero el año está indicado claramente en la línea 278: han transcurrido dos años desde la composición del Neptuno Alegórico (1680), causa del "enojo" de Núñez ${ }^{53}$. La falta de fecha es muy explicable si Sor Juana puso personalmente su carta en manos de

51 El texto de PAZ procede de TAPIA ${ }^{1}$. En TAPIA ${ }^{2}$ hay una reproducción fotográfica del manuscrito, y en la transcripción se han corregido algunos errores. Paz observa en la Carta "imperfecciones y descuidos" no atribuibles al copista, si bien "ni se rompe la concordancia ni se atenta contra la lógica" (p. 634). De hecho, la concordancia se rompe algunas veces, por ejemplo en la líneas 157 ss.: “¿Quién ha prohivido [los estudios privados] a las mugeres? $¿$ No tienen alma racional...? Pues ¿por qué no gozará el privilegio de la ilustración...? ¿No es capaz de tanta gracia...?", etc. (y cf. infra, p. 656, anotación M). También puede parecer "descuido" la abundancia de pues en el espacio de 15 líneas (198 ss.): "Pues... ¿no puede esto hacerse saviendo...? Pues ¿por qué para salvarse...? Pues ¿por qué le ha de ser más acepta...? Pues ¿por qué esta pesadumbre...? Pues ¿quál era el dominio...? Pues quando ello sucedió..." La Carta fue escrita por una pluma muy ducha en escaramuzas dialécticas y muy conocedora de los adornos literarios - donde hay que incluir los arcaísmos aína (15) y norabuena (204) - , pero, evidentemente, no estaba destinada a la luz pública.

52 Plausible conjetura del canónigo Octaviano Valdés (apud TAPIA ${ }^{2}$, p. 10). Plancarte y Navarrete se trasladó con su biblioteca a Monterrey en 1921, al ser nombrado arzobispo de Linares-Monterrey.

53 Don Ezequel Chávez creía que Núñez se había retirado de la asistencia de Sor Juana "desde poco más de dos años antes de la muerte de ésta" (CHÁVEZ1 ${ }^{1}$, p. 354), o sea, digamos, a fines de 1692. Y esos diez años trans- 
Núñez, al final de una de sus conversaciones, o quizá de una de sus confesiones. Dado el asunto que tenía que tratar con él, es natural que haya preferido emplear la escritura. Habría sido incómodo tratarlo de viva voz.

"La grafía es de comienzos del siglo XVIII", dice TAPIA ${ }^{1}, p$. 19. También podría ser de fines del XVII. Una circunstancia curiosa es que los últimos renglones de la Carta (a partir de "Y no obstante, si en este manifiesto...", lín. 310), aunque escritos, al parecer, con la misma tinta y la misma pluma, son de letra claramente distinta de la del resto. He corregido los errores que me parecen más visibles. Salvo unas pocas excepciones - Sr., Sra., Sres., V.R. (Vuestra Reverencia)-, resuelvo las abreviaturas. Transcribo como $I$ - la $Y$ - inicial de Yglesia, etc., y como $u$ - la $v$ inicial de vno, vnico, etc. Suprimo muchas mayúsculas y modernizo la acentuación y la puntuación. También la división en párrafos es mía (en el manuscrito, el único punto y aparte es el de la lín. 32). En el aparato crítico, $M$ designa el manuscrito de Monterrey, $\mathrm{T}^{1}$ y $\mathrm{T}^{2}$ designan las dos ediciones de TAPIA - cuando coinciden, sólo $\mathrm{T}$ - , y $\mathrm{P}$ designa la de PAZ (cuando falta $\mathrm{P}$, quiere decir que su texto es el de $\mathrm{T}^{1}$ ). Las versalitas marginales remiten a las anotaciones de las pp. 642 ss.

curridos entre 1682 y 1692, que ahora se nos muestran como el gran período de libertad y fecundidad en el ser y el quehacer de Sor Juana, los imaginaba él como un patético y prolongado choque de almas. Cf., por lo demás, BÉNASSY, p. 178: "Il est plus que probable que D. Antonio Núñez a veillé discrètement à ce que la gloire de notre auteur à Mexico ne prenne pas une forme trop spectaculaire. Par exemple, il aura peut-être empêché la représentation de pièces de Sor Juana [!]...", y PAZ, p. 356: "Ni Sor Juana cambió de vida ni él se retiró, sino que siguió siendo su confesor". Sin embargo, estos dos autores supusieron, correctamente, que la ruptura bien pudo ocurrir antes de 1692: "Une hypothèse très vraisemblable serait que celle-ci [la separación] ait commencé lors de la période la plus brillamment mondaine de la vie de Sor Juana, dans les années 1680-1688" (BÉNASSY, p. 173); "No sin dudas he dado como fecha del retiro de Núnez... los primeros meses de $1691 \ldots$ Pero no es imposible que el padre Antonio se haya retirado antes", "bastante antes", pues "desde 1680 se vio claro que Sor Juana... estaba decidida a participar más y más en la vida literaria y sus agitaciones" (PAZ, pp. 552-553). Cf. ya DOROTHY SCHONS, "Some Obscure Points in the Life of Sor Juana Inés de la Cruz", MPh, 24 (1926), p. 153, nota 16: el distanciamiento "must have taken place during Juana's greatest worldly activity, i.e. between 1680 and 1690". 


\section{Carta de la Madre Juana InÉS de la Gruz ESCRIPTA A EL R. P. M. ANTONIO NÚÑEZ, DE LA COMPAÑÍA DE JESÚS}

\section{Pax Christi}

Aunque ha muchos tiempos que varias personas me han informado de que soi la única reprehensible en las conversaciones de V.R., fiscalizando mis acciones con tan agria ponderación como llegarlas a escándalo público* y otros epítectos no menos horrorosos, y aunque pudiera la propria

10 conciencia moverme a la defensa, pues no soi tan absoluto dueño de mi crédito que no esté coligado con el de un linaje que tengo y una communidad en que vivo, - con todo esto, he querido sacrificar el sufrimiento a la summa veneración y filial cariño con que siempre he respectado a V.R., que-

15 riendo más aína que cayessen sobre mí todas las objecciones que no que pareciera passaba yo la lígnea de mi justo y debido respecto en redargüir a V.R. (en lo qual confiesso ingenuamente que no pude merecer nada para con Dios, pues fue más humano respecto a su persona que christiana

20 paciencia), y esto no ignorando yo la veneración y crédito grande que V.R., con mucha razón, tiene con todos, y que le oyen como a un oráculo divino, y aprecian sus palabras como dictadas del Espíritu Santo, y que quanto mayor es su authoridad* tanto más queda perjudicado mi crédito,

25 - con todo esto, nunca he querido asentir a las instancias que $\mathrm{a}^{*}$ que responda me ha hecho no sé si la razón o si el amor proprio (que éste tal vez con capa de razón nos arras-

$A$ tra), juzgando que mi silencio sería el medio más suave para que V.R. se desapasionasse, hasta que con el tiempo

30 he reconocido que antes parece que le irrita mi paciencia, y assí determiné responder a V.R., salvando y suponiendo $\mathrm{mi}$ amor, mi obligación y mi respecto.

La materia, pues, de este enojo de V.R., mui amado padre y señor mío, no ha sido otra que la de estos negros

35 versos de que el Cielo tan contra la voluntad de V.R. me

8. Palabras subrayadas en $\mathbf{M}$.

24. El copista había escrito credito (cf. unas palabras después), pero tachó la palabra y escribió en seguida authoridad.

26. M ha. 
dotó. Éstos he rehusado summamente el hacerlos, y me he excusado todo lo posible, - no porque en ellos hallase* yo razón de bien ni de mal, que siempre los he tenido (como lo son) por cosa indiferente; y aunque pudiera decir quán-

40 tos los han usado, santos y doctos, no quiero intrometerme* a su defenza, que no son mi padre ni mi madre: sólo digo que no los hacía* por dar gusto a V.R., sin buscar ni averiguar la razón de su aborrecimiento - que es mui proprio de el amor obedecer a ciegas, demás* que con esto

45 también me conformaba con la natural repugnancia que siempre he tenido a hacerlos, como consta a quantas personas me conocen-, pero esto no fue posible observarlo con tanto rigor que no tuviesse algunas excepciones, tales como dos villancicos a la Santíssima Virgen que, después

50 de repetidas instancias, y pausa de ocho años, hice con venia y licencia de V.R., la qual tuve entonces por más necesaria que la de el Sr. Arzobispo Virrey, mi prelado,

$B$ y en ellos procedí con tal modestia, que no consentí en los primeros poner mi nombre, y en los segundos se puso

55 sin consentimiento ni noticia mía, y unos y otros corrigió antes V.R.

A esto se siguió el Arco de la Iglesia. Ésta es la irremisible culpa mía, a la qual precedió avérmel[o] ${ }^{*}$ pedido tres o quatro vezes, y tantas despedídome yo, hasta que vinie-

60 ron los dos señores juezes hazedores, que antes de llamarme a mí llamaron a la madre priora y después a mí, y mandaron en nombre del Excelentíssimo Sr. Arzobispo lo hiciese, por- [fol. 161r] que assí lo avía votado el Cavildo pleno, y aprobado Su Excelencia. - Aora quisiera yo que V.R.,

65 con su clarísimo juicio, se pusiera en mi lugar y, consulta $[\mathrm{do}]^{*}$, ¿qué respondiera en este lance? ¿Respondería que no podía? Era mentira. ¿Que no quería? Era inobediencia. ¿Que no savía? Ellos no pedían más que hasta donde supiesse. ¿Que estaba mal votado? Era, sobre des-

70 carado atrevimiento, * villano y grosero desagradecimiento a quien me honrraba con el concepto de pensar que savía

37. $\mathrm{T}^{1}$ hayase; corregido en $\mathrm{P}$ y en $\mathrm{T}^{2}$.

40. $\mathrm{T}$ entrometerme.

42. $\mathrm{T}^{1}$ haria; corregido en $\mathrm{T}^{2}$.

44. $\mathrm{P}$ además.

58. $M$ avermela; yo corrijo.

66. M consultara; yo corrijo.

70. T Era sobredescarado atrevimiento. 
hacer una muger ignorante lo que tan lucidos ingenios soli-

$C$ citaban: luego no pude hacer otra cosa que obedecer.

Éstas son las obras públicas que tan escandalizado tie-

75 nen a el mundo y tan dedificados* a los buenos, y assí vamos a 1[a]s no públic[a]s:* apenas se hallará tal o qual coplilla hecha a los años o* a el obsequio de tal o tal persona de mi estimación, y a quienes he debido socorro en

$D$ mis necesidades (que no han sido pocas, por ser tan pobre

80 y no tener renta alguna); una loa a los años del Rey nuestro señor hecha por mandato del mismo Excelentíssimo Sr. D. fray Payo, [y] otr[a] ${ }^{*}$ por orden de la Excelentíssima

E Sra. Condesa de Paredes.

Pues aora, padre mío y mi señor, le suplico a V.R.

85 deponga por un rato el cariño de el proprio dictamen (que aun a los mui santos arrastra) y dígame V.R.: ya que en su opinión es pecado hacer versos, ¿en quál de estas ocaciones ha sido tan grave el delicto de hacerlos? Pues quando fuera culpa (que yo no sé por qué razón se le pueda llamar

90 assí), la disculparan las mismas circunstancias y ocaciones que para ello he tenido, tan contra mi voluntad. Y esto bien claro se prueba. Pues en la facilidad que todos saven que tengo, si a* éssa se juntara motivo de vanidad (quizá lo es de mortificazión), ¿qué más castigo me quiere V.R.

95 que el que entre los mismos aplausos, que tanto [1]e duelen, ${ }^{*}$ tengo? ¿De qué embidia no soi blanco? ¿De qué mala intención no soi objecto? ¿Qué acción hago sin temor? ¿Qué palabra digo sin recelo?* Las mugeres sienten que las exceda. ${ }^{*}$ Los hombres, que paresca que los igualo. Unos

100 no quisieran que supiera tanto. Otros dicen que avía de saver más, para tanto aplauso. Las viejas no quisieran que

$F$ otras supieran más. Las mozas, que otras parescan bien. $Y$ unos y otros, que viesse conforme a las reglas de su dictamen. Y de todo junto* resulta un tan estraño género de

105 martirio qual no sé yo que otra persona aya experimen-

75. P edificados:

76. M los no publicos; yo corrijo.

77. $\mathrm{T}^{1}$ omite $o$ ("a los años, al obsequio"); corregido en $\mathrm{T}^{2}$.

82. M D. fr. Payo, otro...; $\mathrm{T}^{1}$ otra; $\mathrm{T}^{2}$ otro; yo añado la conjunción $y$.

93. M ha.

96. $M$ tanto se duelen (palabras añadidas en interlínea); yo corrijo.

98. El copista había escrito reflexa, pero lo tachó y escribió en seguida recelo.

99. M Las mugeres sienten que las excedan los hombres, que...; yo corrijo.

104. $\mathrm{M}$ de todos juntos; yo corrijo; $\mathrm{T}^{1}$ puntos; $\mathrm{T}^{2}$ juntos. 
tado. ¿Qué más podré decir ni ponderar? Que hasta el hacer esta forma de letra algo razonable me costó una prolija y pesada persecuzión, no más de porque dicen que parecía letra de hombre y que no era decente, conque me obli-

110 garon a malearla adrede, y de esto toda esta communidad es testigo. En fin, ésta no era* materia para una carta, sino para muchos volúmenes mui copiosos.

Pues ¿qué [he]chos* son éstos tan culpables? Los aplausos y celebraciones vulgares ¿los solicité? Y los particula-

115 . res favores y honrras de los Excelentíssimos Sres. Marquezes, que por sola su dignación y sin igual humanidad me hacen, ¿los procuré yo? Tan a la contra sucedió, que la madre Juana de San Antonio, priora deste convento y persona que por ningún caso podrá mentir, es testigo de que

120 la primera vez que Sus Excelencias honrraron esta casa, le pedí licencia para retirarme a la celda y no verlos ni ser vista (¡como si Sus Excelencias me huviessen hecho algún daño!), sin más motivo que huir el aplauso, que assí se con-

$G$ vierte en tan pungentes espinas de persecución; y lo huviera

125 conseguido a no mandarme la madre priora lo contrario [fol. 161v]. Pues ¿qué culpa mía fue el que Sus Excelencias se agradassen de mí (aunque no avía por qué)?* ¿Podré yo negarme a tan soberanas personas? ¿Podré sentir el que

$H$ me honrren con sus visitas? V.R. save mui bien que no,

130 como lo experimentó en tiempo de los Excelentíssimos Sres. Marquez[es]* de Manzera, pues oí yo a V.R. en muchas ocaciones quexarse de las ocupaciones a que le hacía faltar la asistencia de Sus Excelencias, sin poderla no obstante dexar. Y si el Excelentíssimo Sr. Marquez de Man-

135 zera entraba quantas vezes quería en unos conventos tan santos como Capuchinas y Theresas, y sin que nadie lo tuviesse por malo, ¿cómo podré yo resistir que el Excelentíssimo Sr. Marquez de la Laguna entre en éste? (demás que yo no soy prelada, ni corre por mi cuenta su govierno).

140 Sus Excelencias me honrran porque son servidos, no porque yo lo meresca, ni tampoco porque a el principio lo solicité. Yo no puedo, ni quisiera aunque pudiera, ser tan bár-

111. T será.

113. $\mathrm{M}$ dhos (abreviatura de dichos); $\mathrm{T}$ dichos; yo corrijo.

127. M se agradassen de mi? Aunq no avia $p^{\circ}{ }^{\circ}$ que, podre...; yo corrijo.

131. M Marquez; ya P corrige marqueses. 
baramente ingrata a los favores y cariños ( $\tan$ no merecidos, ni servidos) de Sus Excelencias.

145 Mis estudios no han sido en daño ni perjuicio de nadie, mayormente aviendo sido tan summamente privados que no me he valido ni aun de la dirección de un maestro, sino

I que a secas me lo he avido conmigo y mi trabajo, - que no ignoro que el cursar públicamente las escuelas no fuera

150 decente a la honestidad de una muger, por la ocacionada familiaridad con los hombres, y que ésta sería la razón de $\mathrm{p}$ [rohibi] $\mathrm{r}^{*}$ los estudios públicos; y el no diputarles* lugar señalado para ellos será porque, como no las ha menester la república para el govierno de los magistrados (de que

155 por la misma razón de honestidad están excluidas), no cuida de lo que no le* ha de servir; pero los privados y particu-

$J$ lares estudios ¿quién los ha prohivido a las mugeres? ¿No tienen alma racional como los hombres? Pues ¿por qué no gozará el privilegio de la ilustración de las letras con ellos?*

160 ¿No es capaz de tanta gracia y gloria de Dios como la suya? Pues ¿por qué no será capaz de tantas noticias y siencias, que es menos? ¿Qué revelación divina, qué determinación de la Iglessia, * qué dictamen de la razón hizo para nosotras tan severa ley? ¿Las letras estorvan, sino que antes

165 ayudan, a la salvación? ¿No se salvó San Agustín, San Ambrosio y todos los demás Santos Doctores? Y V.R., cargado de tantas letras, ¿no piensa salvarse? $Y$ si me responde que en los hombres milita otra razón, digo: ¿no estudió Santa Catalina, Santa Ge[r]trudes, * mi madre Santa Paula, 170 sin estorvarle a su alta contemplación ni a la fatiga de sus fundaciones el saver hasta griego; el aprehender hebreo; enseñada de mi padre San Gerónimo, el resolver y el entender las Santas Escripturas, como el mismo Santo lo dice, ponderando también en una epístola suya en todo género

175 de estudios doctíssima a Ble[s]illa, * hija de la misma santa, y en tan tiernos años que murió de veinte? Pues ¿por qué en mí es malo lo que en todas fue bueno? ¿Sólo a mí me

152. M publicar...disputarles; yo corrijo.

156. $M$ les; yo corrijo.

159. P ellas.

163. Después de Iglessia, el copista escribió hizo p. ${ }^{a}$ nosotras (cf. unas palabras después), y luego lo tachó.

169. M Getrudez; T Gertrudes.

175. M Blegilla; yo corrijo. 
estorvan los libros para salvarme? Si he leído los poetas* y oradores prophanos (descuido en que incurrió el mismo

180 Santo), también leo lọs Doctores Sagrados y Santas Escripturas, -demás que a los primeros no puedo negar que les debo innumerables bienes y reglas de bien vivir, porque ¿qué christiano no se corre de ser iracundo a vista de la paciencia de un Sócrates gentil? ¿Quién podrá ser ambi-

185 cioso a vista de la modestia de Diógenes Cínico?* ¿Quién no alaba a Dios en la inteligencia de Aristóteles? Y, en fin, ¿qué católico no se confunde si contempla [fol. 162r] la summa de virtudes morales en todos los philósofos gentiles? ¿Por qué ha de ser malo que el rato que yo avía de

190 estar en una reja hablando disparates, o en una celda mormurando quanto passa fuera y dentro de cassa, o pelea[ndo] ${ }^{*}$ con otra, o riñendo a la triste sirviente, o bagando por todo el mundo con el pensamiento, lo gastara en estu-

$K$ diar, y más quando Dios me inclinó a esso, y no me pare-

195 ció que era contra su ley santíssima ni contra la obligación de mi estado? Yo tengo este genio. Si es malo, yo me hize. Nací con él y con él he de morir. V.R. quiere que por fuerza

$L$ me salve ignorando. Pues, amado padre mío, ¿no puede esto hacerse saviendo, que a el fin es camino para mí más

200 suave? Pues ¿por qué para salvarse ha de ir por el camino

$M$ de la ignorancia si es repugnante a su natural? ¿ ${ }^{N}$ os Dios, como summa bondad, summa saviduría? Pues ¿por qué le ha de ser más acepta la ignorancia que la ciencia? Sálvesse San Antonio con su ignorancia santa, norabuena, que

205 San Agustín va por otro camino, y ninguno va herrado.

Pues ¿por qué es esta pesadumbre de V.R., y el decir que a saver que yo avia de hacer versos no me huviera entrado religiosa, * sino casádome? Pues, padre amantíssimo (a quien forzada y con vergüenza insto lo que no quisiera tomar en

210 voca), ¿quál era el dominio directo que tenía V.R. para

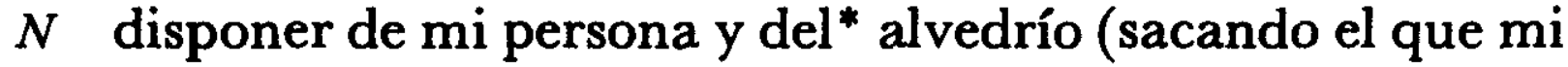
amor le daba y le dará siempre) que Dios me dio? Pues quando ello sucedió, avía mui poco que yo tenía la dicha

178. M profetas; yo corrijo.

185. M Sinico; T Cínico.

192. M pelear; yo corrijo.

208. El copista había escrito mo (evidentemente, monja); lo tachó, y escribió en seguida religiosa. Toda esta frase está subrayada.

211. El copista había escrito de $m i$, y luego escribió $l$ encima de $m i$. 
O de conocer a V.R.; y, aunque le debí summos deseos y

215 solicitudes de mi estado, que estimaré siempre como debo, lo tocante a la dote mucho antes de conocer yo a V.R. lo tenía ajustado* mi padrino el capitán D. Pedro Veláz-

$P \quad$ quez de la Cadena, y ajenciádomelo estas mismas prendas en las quales, y no en otra cosa, me libró Dios el

220 remedio. Luego no ay sobre qué caiga tal proposición, aunque no niego deberle a V.R. otros cariños y agasajos muchos que reconoceré eternamente, tal como el de $Q$ pagarme maestro, y otros.

Pero no es razón que éstos no se continúen, sino que

225 se ayan convertido en vituperios, y en que no aya conversación en que no salgan mis culpas, y sea el thema espiritual el zelo de V.R. [por] mi conversión. ${ }^{*}$ ¿Soi por ven-

$R$ tura herege? Y si lo fuera, ¿avía de ser santa a pura fuerza? Ojalá y la santidad fuera cosa que se pudiera mandar, que

230 con esso la tuviera yo segura. Pero yo juzgo que se persuade, no se manda; y si se manda, prelados he tenido que lo hicieran, - [ues] ${ }^{*}$ los preceptos y fuerzas exteriores, si son moderados y prudentes, hacen recatados y modestos; si son demaciados, hacen desesperados; pero santos,

235 sólo la gracia y auxilios de Dios saven hacerlos.

¿En qué se funda, pues, este enojo, en qué este desacreditarme, en qué este ponerme en concepto de escandalosa con todos? ¿Canso yo a V.R. con algo? ¿Hele pedido alguna cosa para el socorro de mis necesidades, o le he 240 molestado con otra espiritual ni temporal? ¿Tócale a V.R. mi correpción por alguna razón de obligación, de parentesco, ${ }^{*}$ crianza, prelacía o tal que cosa? Si es mera caridad, paresca mera caridad y proceda como tal, suavemente, que el exasperarme no es buen modo de reducirme, ni yo

245 tengo tan servil natural* que haga por amenasas lo que no me persuade la razón, ni por respectos humanos lo que no hago por Dios, - que el privarme yo de todo aquello que me puede dar gusto, aunque sea mui lícito, es bueno que yo lo haga por mortificarme quando yo quiera hacer 250 penitencia, pero no para que V.R. lo quiera conseguir a

217. $\mathrm{T}^{1}$ aprestado; corregido en $\mathrm{T}^{2}$.

227. $\mathrm{M}$ de V.R. mi conversacion; yo corrijo.

232. M pero; yo corrijo.

242. $\mathrm{T}^{1}$ parentezco; corregido en $\mathrm{P}$ y en $\mathrm{T}^{2}$.

245. T naturaleza. 
$S$ fuerza de reprehenciones, y éstas no a mí en secreto, como ordena la paternal correpción (ya que V.R. ha dado en ser mi padre, cosa en que me tengo [po]r* mui dichosa), sino públicamente con todos, donde cada uno siente como

255 entiende [fol. 162v] y habla como siente.

Pues esto, padre mío, ¿no es preciso yo lo sienta de una persona que con tanta veneración amo y con tanto amor reverencio y estimo? Si estas reprehenciones cayeran sobre alguna communicación escandalosa mía, soi tan dócil que

260 (no obstante que ni en lo espiritual ni temporal he corrido

$T$ nunca por cuenta de V.R.) me apartara de ella y procurara enmendarme y satisfacerle, aunque fuera contra mi gusto; pero si no es sino por la contradicción de un dictamen que en substancia tanto monta hacer versos como no

265 hacerlos, y que éstos los aborresco de forma que no avrá para mí penitencia como tenerme siempre haciéndolos, ¿por qué es tanta pesadumbre?

Porque si por contradicción de dictamen huviera yo de hablar apassionada* contra V.R. como lo hace V.R. con-

270 tra mí, infinitas ocaciones suyas me repugnan summamente (porque, a el fin, el sentir en las materias indiferentes es aquel alius sic et alius sic), pero no por esso las condeno, sino que antes las venero como suyas y las defiendo como mías, y aun quizá las mismas que son contra mí, llamán-

275 dolas buen zelo, summo cariño y otros títulos que sabe inventar mi amor y reverencia quando hablo con los otros. Pero a V.R. no puedo dexar de decirle que rebozan ya en el pecho las quejas que en espacio de dos* $^{*}$ años pudiera

$U$ aver dado; y que pues tomo la pluma para darlas, redar-

280 guyendo a quien tanto venero, es porque ya no puedo más, - que como no soi tan mortificada como otras hijas en quien se empleara mejor su doctrina, lo siento demasiado.

Y assí le suplico a V.R. que si no gusta ni es ya servido favorecerme (que esso es voluntario) no se acuerde

285 de mí, que aunque sentiré tanta pérdida mucho, nunca podré quejarme, que Dios que me crió y redimió, y que usa conmigo tantas misericordias, proveherá con remedio para mi alma, que esper[o]* en su vondad no se perderá,

253. M me tengo ser; yo corrijo.

269. $\mathrm{T}$ apasionadamente.

278. $\mathrm{T}$ los.

288. M espera; yo corrijo. 
$V$ aunque le falte la dirección de V.R., que a el* cielo hacen 290 muchas llaves, y no se estrechó a un solo dictamen, sino que ay en él infinidad de manciones para diversos genios, y en el mundo ay muchos theólogos, - y quando faltaran, en querer más que en saver consiste el salvarse, y esto más estará en mí que en el confesor. ¿Qué precisión ay en que 295 esta salvación mía sea por medio de V.R.? ¿No podrá ser por otro? ¿Restringióse y limitóse la misericordia de Dios

$X$ a un hombre, aunque sea tan discreto, $\tan$ docto y tan santo como V.R.? No por cierto, ni hasta aora he tenido yo luz particular ni inspiración del Señor que assí me lo

300 ordene. Conque podré governarme con las reglas genera-

$Y$ les de la Sancta Madre Iglesia mientras el Señor no me da luz de que haga otra cosa, y elexir libremente padre espiritual el que yo quisiere, que si como Nuestro Señor inclinó a V.R. con tanto amor y fuerza mi voluntad con-

305 formara también mi dictamen, no fuera otro que V.R., a quien suplico no tenga esta ingenuidad a atrevimiento ni a me- [fol. 163r] nos respecto, sino a sencillés de mi corazón con que no sé decir las cosas sino como las siento, y antes he procurado hablar de manera que no pueda dejar

310 a V.R. rastro de sentimiento o quexas. Y, no obstante, si en este manifiesto de mis culpas huviere alguna palabra que aya escripto mala, [será]* inadvertencia, que la voluntad no sólo digo de ofensa, pero de menos decoro a la persona de V.R., desde luego la retracto y doi por mal dicha

315 y peor escripta, y borrara desde luego si advirtiera quál era.

Buelbo a repetir que mi intención es sólo suplicar a V.R. que si no gusta favorecerme, no se acuerde de mí $Z$ si no fuere para encomendarme al Señor, que bien creo de su mucha caridad lo hará con todas veras.

320 Yo pido a Su Magestad me guarde a V.R., como deseo. De este convento de mi padre San Gerónimo de México.

Vuestra Juana Inés de la Cruz [fol. 163v]. 


\section{COMENTARIO Y ANOTACIONES}

Dije al comienzo de estas páginas que el $P$. Calleja no menciona en su Vida de Sor Juana (1700) ningún conflicto con el P. Núñez, y deja la impresión de que la relación fue perfecta de principio a fin. Sin embargo, teniendo en cuenta que durante largos años mantuvo correspondencia epistolar con la monja y fue lo que se llama un amigo íntimo ${ }^{54}$, es claro que estuvo enterado del conflicto. Además, la Condesa de Paredes, y su marido, y su secretario, de vuelta en España, tienen que haberle dado toda clase de noticias sobre el caso. Pero, naturalmente, hubiera sido indecoroso que él, jesuita, dijera la menor palabra ofensiva para Núñez, jesuita. Lo que hace - puesto que la victoria de Sor Juana contra los obstáculos era un rasgo que no podía callarse, y puesto que en 1700 ya todo era historia - es adoptar un tono distante, sentencioso, impersonal:

Ya se sabe que la fortuna se la tiene jurada a la naturaleza, y que el gran lustre de vna habilidad es el blanco a que endereza sus tiros la suerte, mereciendo los que buelan más alto en la esfera de vna comunidad la commiseración que se suele tener de Cicerón y de Aristóteles, porque son afligidos adonde están y alabados adonde no.

Cicerón y Aristóteles, tan alabados aquí en la tierra, donde

54 "Le Père Calleja... n'était probablement jamais allé en NouvelleEspagne", dice BÉNASSY, p. 166. Claro que no. Por si no fuera bien conocida su vida, bastaría leer lo que él mismo dice en la "Elegía" impresa en la Fama: "¡Ay! Prosigamos, Juana, en la esperança / que tuvimos los dos de verme, y verte, / pues ser puede en la Bienaventurança" (cf. "Para leer...", p. 485 , y supra, p. 594 , nota 7). Fue seguramente el profundo tono de intimidad de esta "Elegía" lo que movió a Calleja a publicarla sin su nombre. El autor del epígrafe lo mismo puede ser él que el editor de la Fama, Castorena: "Este papel se halló sin nombre de su autor; sólo parece que se compuso a raíz de llegar a España la nueva de aver muerto la Poetisa'. La nueva debió llegar a España en la segunda mitad de 1695, y en la "Elegía" dice Calleja que su relación con Sor Juana comenzó “ avrá bien sus veinte abriles", lo cual nos lleva al año 1675, cuando hacía siete que Sor Juana había entrado en San Jerónimo. La génesis de la amistad pudo ser ésta: el ex-virrey Mancera regresó a España en 1674, y consta que fue él quien le contó a Calleja el célebre examen palaciego de Juana Ramírez por los cuarenta sabios de México (episodio ocurrido casi diez años antes); Calleja, jesuita desde 1662 o 1663 y unos diez años mayor que Sor Juana (E. URIARTE y M. LECINA, Biblioteca de escritores de la Compañía de Jesús, Madrid, 1930, pp. 52-53), decidió entonces mandarle unos versos, a los cuales contestó ella, trabando así una relación epistolar que duró quizá hasta 1693, y de la cual, por desgracia, nadie ha encontrado huella. 
ya no están, son "afligidos adonde están", o sea en el infierno. ¡Pobrecillos! ${ }^{55}$ Así también, alguien que vuela alto y a quien su "suerte", su "fortuna", ha llevado a vivir "en la esfera de vna comunidad", es digno de lástima: su esfera es un infierno, aunque fuera de ella todo sea aplausos. Y a continuación explica Calleja a cuento de qué viene esa reflexión: Sor Juana vivió un infierno. Este párrafo merece ser leído después de la Carta de 1682: a su luz, el vago algunos de Calleja se convierte sin violencia en un él muy preciso: el P. Núñez. Prosigue así Calleja:

Sobre componer versos tuvo la Madre Juana Inés bien autorizadas contradiciones ${ }^{56}$ de que no debemos aquí lastimarnos, o porque los aprobantes de su Primer Tomo riñeron por ella este due${ }^{10}{ }^{57}$, o porque el buen gusto de los espíritus poéticos suele convertir en sazón donosa estos pesares, que, referidos en consonantes de alegre quexa, hazen risueña la pesadumbre ${ }^{58}$. Sólo nos debemos com-

${ }^{55}$ Ésta es la única interpretación posible. Obviamente, Calleja alude a un chiste escolástico: “ ¡Pensar que esos grandes sabios están achicharrándose en el infierno!" (De hecho, con tal de no llegar al Sancte Socrates ora pro nobis de Erasmo, era lícito opinar que no todos los paganos sufren la condenación eterna).

${ }^{56}$ Dos páginas después se referirá Calleja muy desdeñosamente al loco que "con un ímpetu cerril" atacó a Sor Juana por haberse metido en honduras teológicas (cf. "Para leer...", pp. 502-503, nota); pero de quienes la atacaron por la cuestión de los versos se expresa con todo respeto: "bien autorizadas contradiciones". Ésos no eran gente del montón. Sabemos, en efecto, quién era Núñez. Por algo pondera Sor Juana, al comienzo de la Carta, su "authoridad" y "crédito grande". - "Muchos debieron ser los perseguidores y enemigos de la poesía de Sor Juana", dice TAPIA ${ }^{2}$, p. 37. Es probable que los haya habido, pero no que fueran "'muchos". Buena parte del artículo de M.C. BÉNASSY, "Más sobre la conversión de Sor Juana", NRFH, 32 (1983), 462-471, se dedica a demostrar, contra quienes generalizan la hostilidad del estamento eclesiástico, que en éste no faltaban los aplaudidores de Sor Juana. Su demostración podría ampliarse, y mucho, por ejemplo con el testimonio de los colaboradores mexicanos de la Fama. De hecho, no se sabe de nadie, ni seglar ni eclesiástico - fuera de Núñez-, que haya condenado la clase de versos que Sor Juana componía. Todo lo contrario. La "esfera" de infierno se mantuvo en los límites de la comunidad de San Jerónimo.

57 En efecto, los dos "aprobantes" o prologuistas de la Inundación Castálida, fray Luis Tineo y Francisco de las Heras, se encargaron en 1689 de esa tarea apologética (cf. infra, nota 62). Las palabras de Calleja fueron mal entendidas por Joseph de Miravel y Casadevante, traductor-adaptador del célebre Dictionnaire de Louis Moreri (1753). En el artículo que consagra a Sor Juana, después de decir que ésta "padeció muchas persecuciones", añade: "sería sin duda el motivo lo díscolos que estuvieron entre sí [!] los aprobantes del Primer Tomo": pasaje citado por MAZA, p. 304. El propio MAZA, p. 54, hace esa errónea lectura. Cf. "Para leer...", p. 467, nota 90.

58 Alude Calleja, evidentemente, a "consonantes" como los sonetos 
padecer del tiempo en que tuvo entredicho la Madre Juana el estudio de las ciencias mayores, por precepto casero, aconsejado, sin quizás, de algunos ánimos cuyos juyzios no saben descansar el dictamen sino en lo más seguro, como si esto en el trato humano pudiesse tener límite, o como si no pudiera ser aun laudable lo que es competentemente seguro, en especial aviendo pareceres doctíssimos de que, entre dos extremos, el más y el menos harán diferencia en la perfección, no en la legalidad.

Poco después, Calleja da otra razón para no extenderse en este particular: "Quien... quisiere ver vna cabal satisfación [una defensa circunstanciada], lea la Respuesta de la Madre Juana a la ilustríssima Philotea, que va impressa para honra única deste Tercer Tomo', - ese mismo tomo para el cual escribe él su Vida. En la Respuesta, 736-739, Sor Juana explica, en efecto, lo del " precepto casero": es el caso de la "prelada muy santa y muy cándida" que le prohibió el estudio. Hay una discrepancia significativa: Sor Juana da a entender que la prelada procedió motu proprio (creía, la pobre, "que el estudio era cosa de Inquisición"), mientras que Calleja afirma que ese precepto fue "'aconsejado, sin quizás" -obsérvese el énfasis: no se trata de una conjetura-, por terceras personas. Pero la caracterización de las terceras personas está hecha en un lenguaje escolástico que necesita traducción. Lo que hace Calleja es rebatir la siguiente proposición: 'Las religiosas se han apartado del mundo para dedicarse exclusivamente a la virtud y así asegurar su salvación; están, pues, obligadas a seguir lo más seguro, o sea el camino de la perfección, de la santidad'. La refutación dice: 'Todos los caminos son seguros mientras haya voluntad de salvarse (y además, "en el trato humano", en la realidad concreta, ¿quién tiene derecho a definir "lo más seguro'?); verdad es que unas monjas son más santas y otras menos, pero, mientras no haya diferencia "en la legalidad" (mientras unas y otras cumplan con la regla), no hay por qué fustigar a las no muy santas. Más aún: las señales de santidad de ciertas monjas suelen ser sospechosas; lo más seguro bien puede ser la aurea mediocritas; "'lo que es competentemente seguro" bien puede ser no sólo legítimo, sino aun laudable' ${ }^{59}$. La refutación es casi metafísica,

“'Tan grande, jay Hado! mi fortuna ha sido...?” o " ¿En perseguirme, Mundo, qué interesas?...", donde la pesadumbre, alquitarada por los "espíritus poéticos" de quien la sufrió, ha quedado convertida en belleza.

${ }^{59}$ De manera análoga, al comienzo del Neptuno Alegórico (SJ, t. 4, p. 357), Sor Juana elogia a Cicerón por haber buscado la "mediocridad": "Quod scribimus, nec docti nec indocti legant: alteri enim nihil intelligunt, alteri plus forsan quam de nobis nos ipsi'". In medio virtus. 
pero, leída a la luz de la Carta, resulta enérgica y precisa. Sor Juana, dice Calleja unos párrafos después, supo vencer "las objeciones de los que passan la simple aprehensión por juyzio hecho"'. Traducción: 'Núñez fue uno de esos personajes autoritarios y rigoristas que piensan que su modo personal de ver tiene que convertirse en norma para otros'60. Y éste es, desde luego, el punto capital que repetidas veces toca Sor Juana en la Carta $^{61}$. Calleja pudo haber ayudado a su lejana amiga con consejos y argumentos. Así como Núñez disipó en 1667 los "rezelos" de Juana Ramírez en cuanto a hacerse monja, así Calleja puede habérselos disipado hacia 1681 en cuanto a sacudirse el yugo de tan tiránico director espiritual. La hipótesis no es descabellada.

Al salir a la luz pública en 1689 el Primer Tomo de Sor Juana, donde abundan las composiciones capaces de escandalizar por venir de mano de una monja - nunca se había impreso en España un libro como ése-, sus amigos, y ella misma, deben haber sentido la necesidad de un prólogo destinado a quitarles a las almas pías sus escrúpulos, o sea una refutación de la estrecha filosofía de la santidad cuyo adalid mexicano era Núñez. Se diría que el indicado era el P. Calleja, amigo epistolar de la monja y poeta a su vez. Pero esto, por las razones dichas, no pudo ser. Quien se encargó de escribir ese prólogo galeato fue el viejo fray Luis Tineo de Morales, miembro eminente de la orden premonstratense y amigo, como Calleja, de la Condesa de Paredes. De hecho, como él lo dice, fue la propia Sor Juana quien lo eligió para esa misión. También Tineo se refiere a Núñez en tercera persona de

60 Aprehender, dice el Diccionario, es término filosófico que significa 'percibir simplemente las cosas, sin hacer juicio de ellas'. Nada más contrario a "la simple aprehensión' que el "juyzio hecho", y es peligroso confundir lo uno con lo otro.

61 Cf. infra, pp. 655 y 668 , las anotaciones $L$ e $Y$. El único ejemplo concreto de rigorismo que menciona Calleja es el haber instigado el "precepto casero", de modo que es este incidente el que lleva la carga patética: "Sólo nos debemos compadecer" de ese tiempo en que se le prohibió el estudio a Sor Juana; como si dijera: 'eso fue lo único doloroso' (o lo único infernal). Sor Juana, en cambio, apenas le da importancia al incidente: así como en la Carta (106-111) cuenta casi con risa cómo en una ocasión la obligaron a hacer mal la letra, así en la Respuesta (736-739) cuenta despreocupadamente cómo en otra ocasión consiguieron que se le prohibiera el estudio; fue sólo esa vez; se trataba de una prelada especialmente tonta, y la prohibición no duró mucho: apenas los tres meses (o quizá menos) "que duró el poder ella mandar". Es lógico situar el incidente en la época en que Núñez había dejado de ser el director espiritual de Sor Juana. 
plural, pero la adorna con adjetivos ("los tontos", "'los necios", etc.). He aquí el pasaje pertinente:

¿No es digno de inmortales aplausos [todo lo que hay en este volumen]?... Fuera el negarlo vna torpe ignorancia, fuera vna rústica grosería ${ }^{62} \ldots$ ¿Y bien? Bueno fuera que ignorara yo aora, al cabo de mi vejez, el pecado original en que siempre fueron concebidos los ingenios de esta classe, que es la embidia y emulación de los necios... [Es verdad que hay en el volumen muchas cosas que parecen impropias de una monja]... No digo esto porque yo en esta materia llegue a hacer el menor escrúpulo ${ }^{63}$, antes reconozco que éstas son vnas prendas y habilidades divinas, que Dios las pone en algu-

62 De manera muy parecida el otro prologuista, Francisco de las Heras, dice que fuera una "bisoñería plebeya", fuera una "estolidez rústica" pasmarse de que versos tan buenos sean ide una mujer! Tineo se dirige a quienes puedan censurar a Sor Juana por razones estúpidas (las muchas poesías profanas); Francisco de las Heras, a quienes puedan alabarla por razones también estúpidas (es estúpido creer "que por el sexo se han las almas de distinguir"). Se tiene la impresión de que los dos prologuistas se pusieron de acuerdo para repartirse la tarea apologética.

${ }^{63}$ ¡Como que él mismo, en su mocedad, había escrito poesías profanas y frívolas! Véase, sobre todo esto, mi artículo "Un soneto desconocido de Sor Juana", en la revista Vuelta, 1984, núm. 94, 4-13. Sin embargo, algún "escrúpulo" tendría el viejo monje, a juzgar por la manera sinuosa como expone eso que he resumido entre paréntesis angulares. El párrafo es una serie de imágenes yuxtapuestas. Los versos - dice, en resumen - son contrapeso para el peso del deber ("pensar que no ha de aver contrapesos es no querer nada bueno"), atenuación de los resplandores absolutos que algunos exigen (hasta el sol y la luna "flaquean" a veces), cizaña que hay que perdonar (aunque a su tiempo sea arrancada), flores que anuncian frutos. La imagen de la cizaña, que es la más fuerte, se expone así: " Rara providencia la del padre de familias al cap. 13 de S. Matheo, que no quiso que se arrancasse la zizaña que avía nacido con el trigo hasta que llegasse el tiempo de estar maduras las miesses! Tenga vn poco de paciencia el padre de familias, que tiempo tras tiempo viene; ello madurará y será todo grano". O sea: tenga paciencia el P. Núñez. Hacia el final del prólogo, después de mencionar a los grandes Padres que no se desdeñaron de practicar el don de hacer versos - Tertuliano, Ambrosio, Gregorio Nazianzeno-, escribe Tineo: "Lo mismo digo de Sor Juana, y añado (porque, como dezía el cardenal Belarminio, tengo también mi poco de propheta a lo viejo) que ha de ser muy santa y muy perfecta, y que su mismo entendimiento ha de ser causa de que la celebremos por el S. Agustín de las mugeres". Ahora bien, es curioso que este parrafito se haya suprimido a partir de la $2^{\mathrm{a}}$ edición del Primer Tomo, a la vez que se incluían en ella los cinco "Sonetos burlescos" que tanto escandalizaron a Méndez Plancarte (SJ, t. 1, p. 525), y que muy probablemente se habían eliminado de la $1^{\text {a }}$ edición por "escrúpulo" del propio Tineo. (Hay que tener en cuenta que entre la $1^{\mathrm{a}}$ y la $2^{\mathrm{a}}$ edición no mediaron sino unos cuantos meses, insuficientes para que Sor Juana tuviera nada que ver en el asunto). 
nos sugetos para demonstración de su gran providencia, y motivos admirables de su mayor alabança. Desdichadas prendas y habilidades si huvieran de ser ofensa de Dios. No son sino recreación honestíssima y empleos decentíssimos del religioso más ajustado..., porque ya se ve que es disparate pensar que ha de estar siempre tirada la cuerda al arco ${ }^{64} .$. Lo que veo es que estas gracias Dios no se las da a todos, y particularmente a los tontos; la causa claro está que ellos no la ignorarán, siendo los que todo lo saben. Yo confiesso que de oficio he hecho este reparo, valga lo que valiere, porque, como reconozco que stultorum infinitus est numerus, podrá ser que, entre tantos, no falte alguno de los que baptizan el idiotismo con nombre de santidad, que piense que han de canonizarle con publicar guerra a los consonantes de intra claustra como si fuera a la secta de Lutero. Lo que sé es que los de esta professión saben mejor conceptuar su negocio y cultivar sus conveniencias que los que tratan de cultivar el Parnaso y conceptuar discreciones, con que se puede entender que éstos viven más apartados del mundo.

A la luz de la Carta de Sor Juana, los rasgos de este genérico retrato cobran muy fuerte relieve. Sor Juana se dirige a un hombre sumamente consciente de su fama de discreción y de santidad. Cuando dice al comienzo: "la veneración y crédito grande que V.R., con mucha razón, tiene con todos, y que le oyen como a un oráculo divino y aprecian sus palabras como dictadas del Espíritu Santo" (20-23), y cuando dice al final: "un hombre tan discreto, tan docto y tan santo como V.R." (297), está repitiendo lo que todo el mundo dice en México, y sabe que Núñez lo sabe. Pero su Carta es una negación de la vox populi: la conducta de Núñez para con ella no es la de un hombre "discreto" ni "docto" ni "santo". Sor Juana llega no pocas veces al sarcasmo. Núñez gozaba fama de lector voraz - lo llamaban helluo librorum, según Oviedo-, y Sor Juana se admira de que ese hombre "cargado de tantas letras"', y que aspira a santificarse (167), quiera imponerle a ella, "por fuerza", la vía de la santa ignorancia, la de San Antonio Ermitaño (197-205). Y esto ¿por qué altas razones? Simplemente porque Núñez, a título personal - pero como si hablara ex cathedra-, no aprueba la actividad intelectual de su hija: "estos

64 "Un rato de honesta recreación" les es lícito a las monjas, "por que se afloxe el arco y no se rompa la cuerda de tirante", dirá dos años después el propio Núñez en el Sermón panegyrico en la dedicación del templo de las monjas de San Bernardo, 1691 (citado por BÉNASSY, p. 209, nota 41). Aunque se trata de un lugar común de cualquier literatura - hasta de la hagiográfica-, no es aventurado ver en las palabras de Núñez una réplica a las de Tineo. Como si dijera: 'En eso estamos de acuerdo, pero...' 
negros versos de que el Cielo tan contra la voluntad de V.R. me dotó" (34-36). Núñez tiene derecho a sus opiniones, pero no a imponérselas a ella. En el desarrollo de esta idea prodiga Sor Juana el sarcasmo. Le da una leccioncita al docto Núñez. Le explica que, "en substancia, tanto monta hacer versos como no hacerlos", y que si él los considera cosa mala, esto no la afecta a ella; se trata de una simple y vulgar "contradicción de un dictamen". Si a ésas vamos..., "si por contradicción de dictamen huviera yo de hablar apassionada ${ }^{65}$ contra V.R. como lo hace V.R. contra mí, infinitas ocaciones suyas me repugnan summamente [ = "en infinitos casos estamos en total desacuerdo usted y yo']..., pero no por esso las condeno": cada cual es dueño de sus manías, cosas indiferentes, "aquel alius sic et alius sic" (263-272). Estar pagado del "proprio dictamen" (creer que lo que uno piensa es lo único bueno) no es de doctos ni mucho menos de santos. Sor Juana no debe haber creído que su frase "le suplico a V.R. deponga por un rato el cariño de el proprio dictamen, que aun a los muy santos arrastra" (84-86) fuera a hacerle mella a Núñez. Él está segurísimo de su filosofía de la santidad; en los lugares de la ciudad de México en que está presente -y Núñez, oráculo de la ciudad, está presente en todos-, "no [hay] conversación en que no salgan [a relucir] mis culpas, y sea el thema espiritual el zelo de V.R. por mi conversión. ¿Soi por ventura herege...?”', etc. (225 ss.). Aquí es quizá donde el sarcasmo alcanza su mayor finura. Al mostrarse gravemente preocupado por la salvación del alma de la Madre Juana, Núñez ostenta su propia virtud, su celo por la conversión de una descarriada, la seriedad con que toma su profesión de encaminador de almas, de fabricante de santos. ¿Qué bien hace su papel! ¿Qué varón tan enamorado de la virtud!

En la andanada de Tineo, Núñez es llanamente un mercachifle de la santidad, y lo es por su radical tontería. Núñez es un tonto presumido, de "los que todo lo saben" (y que, por lo tanto, tiene que saber que en la lista de los no agraciados por Dios con ciertos dones están en primer lugar los tontos), un tonto dogmático, "de los que baptizan el idiotismo con nombre de santidad" (quiere imponer la idiotez como norma de vida, y la llama "santa ignorancia"' $)^{66}$, un tonto iluso, que con tratar a la monja poetisa

${ }^{65}$ A Sor Juana la mueve la razón; a Núñez, la pasión. Cf., al comienzo de la Carta (25-29): "[Había pensado quedarme callada], juzgando que mi silencio sería el medio más suave para que V.R. se desapasionasse".

${ }^{66} \mathrm{CHÁVEZ}^{2}$, p. 206, cita el prólogo de Tíneo, pero no parece haberlo leído con atención. Si lo hubiera hecho, seguramente habría descubierto contra quién iba la andanada. 
como si fuera hereje luterana piensa que todo el mundo va a ver en él un santo. En resumidas cuentas, un tonto mañoso y calculador. Sor Juana está encerrada en su convento mientras Núñez anda por la ciudad haciendo lo que hacen "los de esta professión": acusa a Sor Juana de ocuparse en cosas mundanas (leer, escribir), y él gasta el tiempo en chismes y calumnias, seguro de que se está levantando a sí mismo un monumento. El verdadero mundano es él67.

Si las alusiones a Núñez son tan diáfanas en los pasajes que acabo de comentar de la Vida de Calleja y del prólogo de Tineo, no podían serlo menos en la Respuesta a Sor Filotea. He sugerido la posibilidad de que Calleja, en alguna de sus cartas, haya alentado a Sor Juana a cambiar de confesor. Y es indudable que ella, en marzo de 1691, se había deleitado ya con el prólogo de Tineo, impreso en 1689. Aparte de sus propias convicciones, el apoyo de los dos eminentes eclesiásticos, amigos de su amiga la Condesa de Paredes $^{68}$, la hacía pisar terreno firme. Sin embargo, una cosa era aludir a Núñez en Madrid y otra cosa era hacerlo en

$67 \mathrm{El}$ "Mundo" del soneto "En perseguirme, Mundo, ¿qué interesas?..." no puede ser sino Núñez. Ciertamente no se trata del miembro del trío MundoDemonio-Carne, como entiende ElIZABETH LUNA TRAILL, "Estructuras sintácticas y semánticas de un soneto de Sor Juana Inés de la Cruz', $A P, 2$ (1980), 127-137, - la cual, para llegar a esa conclusión, se ha valido, no de la simple inteligencia del soneto, sino de "técnicas científicas" de moda. Sor Juana no iba a cometer el despropósito de decir que el Mundo la "persigue" -injustamente - por poner su entendimiento en las bellezas, por consumir la vida en vanidades. Son cosas que ella no hace. Ella hace todo lo contrario: pone bellezas en su entendimiento y consume útilmente las vanidades de la vida (cf. Carta, 189 ss.: "el rato que yo avía de estar en una reja..."). Si leemos el soneto como dirigido a Núñez ("En perseguirme, Núñez, qué interesas?..."), veremos que es como quintaesencia de la Carta, - quintaesencia tan compacta y breve, que tiene que aguarse para llenar los catorce versos. Desde el punto de vista de la retórica poética, es el soneto más simplón y ripioso de Sor Juana (desde luego, el menos necesitado de un análisis de "estructuras sintácticas y semánticas"). Lo que llama la atención es su desgarbo, su falta de lima: riquezas rima con riquezas (vv. 5 y 8) y entendimiento con entendimiento (vv. 3 y 7); en este caso A. M. P. se vio obligado a remediar el desliz, y sustituyó el segundo entendimiento por pensamiento).

$68 \mathrm{Y}$ no hay que olvidar el apoyo tan cercano y continuo de la propia Condesa. No es aventurado suponer que esta mujer de mundo, con gran experiencia de la Corte madrileña, conocedora de eclesiásticos mucho más ilustrados y humanos que Núñez, fue quien primero vio lo absurdo del "martirio" de su admirada amiga, y quien primero sugirió la ruptura liberadora. ¿Por qué, si no, ese agradecimiento de Sor Juana, tan ilimitado, tan reiterado? Piénsese, sobre todo, en el soneto-dedicatoria de la Inundación Castálida: "El hijo que la esclava ha concebido..." De no haber sido por María Luisa, ¡cuántas admirables cosas de Sor Juana nunca se hubieran escrito! 
México. En la Respuesta, las alusiones al confesor son especialmente cautelosas:

[Quienes más me han hecho sufrir] no son aquellos que con declarado odio y malevolencia me han perseguido, sino los que amándome y deseando mi bien ( $y$, por ventura, mereciendo mucho con Dios por la buena intención) ${ }^{69}$, me han mortificado [con sus preceptos de virtud] (512 ss.).

Algunas veces me pongo a considerar que el que se señala -o le señala Dios, que es quien sólo lo puede hacer - es recibido como enemigo común, porque parece a algunos que usurpa los aplausos que ellos merecen (528 ss.)... Aborrecer al que se señala porque desluce a otros [es máxima impía, pero]... así sucede y así sucedió siempre. Y si no, ¿cuál fue la causa de aquel rabioso odio de los fariseos $^{70}$ contra Cristo...? [Cristo no hacía sino el bien]: ¿pues cómo no le amaban? ¡Ay Dios, que por eso mismo le aborrecían! Júntanse en su concilio y dicen: "Quid facimus, quia hic homo multa signa facit?"... Dar por causal que "hace cosas señaladas" no parece de hombres doctos, como eran los fariseos. Pues así es, que cuando se apasionan los hombres doctos prorrumpen en semejantes inconsecuencias $^{71} \ldots$ ¡Válgame Dios, que el hacer cosas señaladas es causa para que uno muera! (540-594)... Cualquiera eminencia padece esta pensión, pero la que con más rigor la experimenta es la del entendimiento...: [pues], como dijo doctamente Gracián, las ventajas en el entendimiento lo son en el ser..., y así como ninguno quiere ser menos que otro, así ninguno confiesa que otro entiende más, porque es consecuencia del ser más... [La corona de escarnio de Cristo es un gran símbolo]: cabeza que es erario de sabiduría no espere otra corona que de espinas. ¿Cuál guirlanda espera la sabiduría humana si ve la que obtuvo la divina? (608-614)... [También San Pedro tuvo sus " aflicciones" la noche del Jueves Santo]. ¿Por qué? No se dio otra causal sino: "Et hic cum illo erat". Era afecto a la Sabiduría..., andábase tras ella..., y [eso] bastó...: ni faltó soldado de fuera que no le afligiese, ni mujer doméstica que no le aquejase ${ }^{72}$.

${ }^{69}$ Si no dijera "por ventura", sería difícil percibir la ironía. La frase de Tineo: "[ése que piensa] que han de canonizarle con publicar guerra a los consonantes de intra claustra", ha quedado sumamente adelgazada.

${ }^{70}$ Subrayo esta palabra porque sin duda está cargada de intención. Sor Juana hubiera podido decir simplemente "los judíos", como en otros lugares de este pasaje. Fariseos son, típicamente, quienes alardean de conocer toda la Ley y de ser irreprochables en toda su conducta.

71 Cuando los "doctos" se dejan llevar por la pasión (cf. supra, nota 65) caen en las peores "inconsecuencias". También Sor Juana llama tonto a Núñez, pero con muchísimo más comedimiento que Tineo.

72 Sor Juana fue afligida por un "soldado de fuera" (un centurión de la milicia de San Ignacio, de mucho rango "fuera" del convento, pero sin auto- 
Yo confieso que me hallo muy distante de los términos de la sabiduría..., pero todo ha sido acercarme más al fuego de la persecución, al crisol del tormento; y ha sido con tal extremo, que han llegado a solicitar que se me prohiba el estudio. Una vez lo consiguieron..., etc. (724-735).

El pasaje es muy largo; abunda en digresiones, recovecos y arabescos que he suprimido ${ }^{73}$, pero de hecho está diciendo todo el tiempo una misma cosa: que quienes se señalan sufren persecución, sin más causa (o "causal") que el hecho mismo de señalarse. El primer ejemplo - y el más desarrollado- es el de Cristo ${ }^{74}$, la Sabiduría encarnada; el segundo, el de San Pedro, santo amable (entre otras cosas, por sus flaquezas humanas), a quien Sor Juana ha celebrado varias veces; y el tercero, el de ella misma. Tineo había dicho con toda claridad que quienes se señalan están fatalmente expuestos a "la embidia y emulación de los necios". Sor Juana, que habla de "ojeriza", "aborrecimiento", "rigor", "cólera", "rabioso odio"' (y "pesadumbre", "tormento", "martirio"), una sola vez escribe la palabra "envidia" en conexión con el tema básico de la persecución ${ }^{75}$. Pero, cubierto de velos trans-

ridad sobre ella), y aquejada no por una "mujer doméstica", sino por varias (las preladas tontas y sus "preceptos caseros").

${ }^{73}$ Así la digresión sobre el ostracismo en Atenas, ley "por la cual salía desterrado el que se señalaba en prendas y virtudes"' (533 ss.), o la explicación sobre los distintos tipos de coronas que había en la Roma clásica según Plinio y Aulo Gelio (641-655), o la larga consideración (544-572) sobre la hermosura de Cristo ("Si cualquiera belleza humana tiene jurisdicción sobre los albedríos, y con blanda y apetecida violencia los sabe sujetar, ¿qué haría... aquella incomprensible beldad...?", etc.), que precede al "¿pues cómo no le amaban?"

74 "Dans ce passage, l'exégèse de Sor Juana est plus que discutable", dice BÉNASSY, p. 542, nota 19 . Creo que esto es perder de vista el contexto histórico-literario. Es claro que Sor Juana sabía el porqué "profundo" de la Pasión de Cristo; pero la técnica de la oratoria sagrada le permitía entresacar de los evangelios unos cuantos textos y glosarlos de acuerdo con las necesidades de una exposición. En el plano exegético puro es también "discutible" la afirmación de que Simón Pedro pasó un mal rato en casa de Caifás por ser aficionado al saber, pero en el plano exegético-retórico del Barroco es todo un pequeño hallazgo. La Crisis del Sermón de Vieira está hecha en muy buena medida con esa técnica, y Sor Juana, constándole que el obispo de Puebla admira tales primores (cf., en la carta de Sor Filotea, la muy "discutible" explicación de por qué San Mateo llamó "libro" a la genealogía de Cristo), sabe que la mejor manera de decirle algo muy serio, algo que a ella le importa sobremanera decir, es justamente ésa. Por algo el pasaje ocupa más de 200 líneas (525-735).

${ }^{75}$ Lo hace en una de esas escaramuzas exegéticas que Bénassy encuentra discutibles (y que PAZ, p. 633, explica muy bien como "amar por las ondula- 
parentes, el concepto de 'envidia' está presente en todo el pasaje de la Respuesta, visión retrospectiva de la conducta de Núñez. A veces parece Sor Juana a punto de soltar la palabra, como cuando menciona a aquellos que al ver aplaudido a alguien se enfurecen con él por parecerles "que usurpa los aplausos que ellos merecen" (o sea, llanamente, los envidiosos), o cuando comenta la sentencia de Gracián y le explica al obispo de Puebla el mecanismo esencial o existencial de la envidia.

Naturalmente, en 1682, en su Carta de despedida a Núñez, no podía Sor Juana acusarlo de algo tan $\mathrm{feo}^{76}$. No podía decirle: 'Lo que pasa, en el fondo, es que usted me tiene envidia'. La Carta es pasmosamente atrevida, pues contradice y redarguye y refuta punto por punto al docto, sabio y discreto jesuita; pero el atrevimiento tiene sus límites. Sor Juana puede demostrarle a Núñez, sin dejar resquicio de duda, que no es verdad lo que él anda diciendo a los muchos que le hacen caso; hacer versos no es malo; recibir homenajes de los virreyes no es malo; además, ella no ha "procurado"' estos homenajes, no ha "solicitado"' los aplausos de la gente común (lo cual sí sería malo). Pero no puede llegar más allá de los límites de una refutación racional. Ese "más allá" se queda en el aire, al final de la Carta, en forma de una de tantas preguntas retóricas: “ ¿En qué se funda, pues, este enojo, en qué este desacreditarme...?", etc. (236 ss.), que, a diferencia de las demás, tiene dos traducciones, una obvia: 'En nada', y otra menos obvia: 'Yo sé en qué, pero, por respeto a usted, no lo digo'77. Y,

ciones y circunvoluciones"). Cristo reprendió a los dignatarios judíos "llamándolos ladrones y no pastores de ovejas", y ellos se enfurecieron tanto, que a punto estuvieron de lapidarlo; Él se retiró durante un tiempo, pero le llegó la noticia de la muerte de su amigo Lázaro y decidió regresar, cosa que alarmó a los discípulos. Aquí se plantea una quaestio: ¿qué era "más peligroso" para Cristo, el furor de los judíos insultados o lo que esos mismos judíos iban a sentir muy pronto al verle hacer algo tan "señalado" como la resurrección de un muerto? Sor Juana resuelve que el peor peligro era el segundo: "Menos intolerable es para la soberbia oír las reprensiones, que para la envidia ver los milagros" (709-710).

76 La palabra "envidia" figura en la Carta, pero sólo a propósito de peripecias menores, de molestias secundarias: “¿De qué embidia no soi blanco?...", etc. (96 ss.).

${ }^{77} \mathrm{La}$ pregunta que sigue inmediatamente, "¿Canso yo a V.R. con algo?", no tiene sino una traducción ('Yo no le doy lata a usted con nada'), lo mismo que la pregunta anterior, "¿Soi por ventura herege?”' ('Yo no soy hereje') y las demás de la Carta ('Las mujeres son tan inteligentes como los hombres', 'Es saludable leer a los clásicos', 'Usted, según el derecho canónico, no tiene autoridad sobre mí', etc.). El presupuesto de tales preguntas 
bien visto, la segunda traducción equivale a la primera. Sor Juana ha refutado una a una las razones que pudiera tener Núñez para andar diciendo pestes de ella. Pero la razón de Núñez es la razón de la sinrazón. Al igual que la pasión de los celos (su hermana gemela), la pasión de la envidia se caracteriza por ser irracional, por fundarse en nada.

Un complemento (o contrapeso) útil de la Vida de Núñez por su discípulo Oviedo son los documentos acerca de Núñez que se conservan en los archivos de la Compañía y que, publicados en 1970 , no parecen haber sido utilizados por los sorjuanistas ${ }^{78}$. Hay que tener en cuenta las costumbres de los jesuitas. Los superiores de las distintas casas mandan periódicamente informes al provincial acerca de sus respectivos súbditos, y el provincial, a su vez, mantiene al corriente de todo al superior general. Lo bueno de estos documentos es su realismo, su ausencia de colores hagiográficos; se trata de ver cómo es cada uno, qué cualidades y defectos tiene, cómo "pinta". Núñez, nacido en 1618, ingresó en la Compañía en 1637. Era de temperamento arrebatado y activo, y tenía dotes para ser lo que hoy se llama "un ejecutivo" "79. Era de los destinados a "subir", a "llegar". Su curriculum es normal hasta 1660: se inicia como profesor de Latinidad en Valladolid, siendo hermano profeso; hace los estudios de rigor y se ordena de sacerdote; enseña luego Humanidades en Tepotzotlán, Filosofía en el Colegio de San Ildefonso de México, y Teología Moral en Puebla y después en Guatemala, donde en 1656 hace la solemne "pro-

es que las dos partes, la emisora y la receptora, coinciden en la respuesta. Pero al preguntar "¿En qué se funda...?”, no puede Sor Juana insinuar que ella sabe la respuesta: el fundamento del enojo de Núñez, el fondo oculto bajo la vasta superficie visible, no es asunto de ella, sino de la conciencia de Núñez.

78 ZAMBRANO, pp. 513-539. (Estas 27 páginas contienen, aparte de los datos de archivo, noticias de muchas otras fuentes, antiguas y modernas). PAZ no menciona a Zambrano; BÉNASSY lo cita dos veces, pero, curiosamente, ninguna de ellas a propósito de Núñez.

79 En 1638, el maestro de novicios de Tepotzotlán da buenos informes sobre él y dice que es "de complexión sanguínea"; en 1648, siendo ya sacerdote, el superior da también buenos informes y dice que es "de complexión colérico-sanguínea y de aptitud para todo"; en 1650, siendo profesor de Filosofía en San Ildefonso, el superior dice que es "de complexión colérica" y que tiene "aptitud de gobernar". En 1653, siendo profesor de Moral y Escritura en Puebla, el superior informa sólo que es "de mediana salud"'. RAIMUNDO LIDA, HR, 28 (1960), p. 377, comentando el libro del P. Miguel Batllori sobre Gracián y el Barroco (Roma, 1958), dice que el autor suele invitarnos " a vislumbrar el carácter de Gracián... a través de los documentos en que sus superiores lo juzgan, y hasta de indicaciones sobre sus cambios de salud y humor (lo colérico y sanguíneo, lo bilioso y melancólico)". 
fesión de cuatro votos". No se sabe cuándo regresa a México, pero en 1660 ya está aquí: en ese año lo nombran prefecto de estudios mayores del Colegio de San Pedro y San Pablo y es ya calificador del Santo Oficio. En 1663 inicia sus importantísimas funciones de prefecto de la Congregación de la Purísima y en 1664 su abundante producción literaria ${ }^{80}$. Según el P. Gérard Decorme, historiador moderno de la Compañía en México (citado por ZAMBRANO), Núñez "fue escogido para dirigir las conciencias de dos arzobispos y tres virreyes": Las noticias conocidas se refieren a dos virreyes: el Conde de Baños (1660-1663) y el Marqués de Mancera (1664-1673) ${ }^{81}$. Estos quehaceres -el de calificador del Santo Oficio, el de prefecto de la Purísima y el de confesor virreinalle dieron al jesuita un campo amplísimo en que extender su fama de sabio omnisciente, de "oráculo universal", tan reconocida por toda la sociedad. Pero también en la Orden siguió subiendo Núñez: a comienzos de 1677 fue nombrado rector de San Pedro y San Pablo, y tres años después provincial de la Compañía (con lo que vino a ser el jesuita número uno de la Nueva España). Pero allí terminó su "promisora" carrera dentro de la Compañía. En noviembre de 1680 , cuando Sor Juana deslumbró a la sociedad con el Arco de la Iglesia, hacía dos meses que Núñez había dejado de ser provincial; lo había sido sólo durante parte de ese año ${ }^{82}$. Además, ya no era frecuentador del palacio virreinal. Si don Ezequiel Chávez hubiera tenido a la mano estas precisiones cronológicas, habría llegado mucho más lejos en su intento de comprender al hombre y de analizar el "choque de almas". Porque el

80 ZAMBRANO, pp. 517-521. De 1664 son sus escritos más antiguos: el Comulgador penitente de la Purissima: Explicación mystica de la Regla 18, que es de la confessión y comunión, obra editada por D. Diego Gil Guerrero, "su actual prefecto", y el Compendio de las obligaciones comunes y medios generales para cumplirlas..., que se propone a la Congregación de la Puríssima, compuesta de sacerdotes y seglares, obra editada por el $\mathrm{Br}$. Antonio de Salvatierra, presbítero, "su actual prefecto" (sobre los prefectos "actuales" cf. supra, p. 602, nota 23). El Coloquio sobre los actos de contrición (también de 1664, según BERISTÁIN) no ha sido descrito por ningún bibliógrafo moderno.

${ }^{81}$ En la Carta, 130-134, Sor Juana le recuerda a Núñez cuánto tiempo le consumía la "asistencia" de Mancera y de su mujer. Sobre el Conde de Baños véase supra, p. 603. Núñez y Sor Juana se conocieron en el palacio de Mancera a mediados de 1667 (cf. infra, pp. 660-661, anotación $P$ ):

82 En "el pliego casu mortis" del provincial anterior, muerto en febrero, se designaba como sucesor a Núñez; pero en septiembre llegó carta del superior general, en que nombraba provincial a otro (ZAMBRANO, p. 525). Núñez fue un interino. (Se equivoca PAZ, p. 528, al decir que fue provincial "durante dos años"). El Papa Negro siempre ha estado bien informado, y evidentemente los informes que tenía sobre ese lejano súbdito no eran del todo entusiastas. 
sanguíneo y/o colérico Núñez no toleraba verse postergado o eclipsado ${ }^{83}$. Cuando Sor Juana escribía su Carta, hacía unos dos años que Núñez sufría eclipse: ya no contaba tanto en la sociedad, mientras que ella era cada vez más aplaudida; habían pasado los tiempos en que él era recibido por los virreyes en su palacio; ahora los virreyes iban a buscarla a ella en su convento: inde ira. Por algo en la Carta, 113-144, razona Sor Juana tan circunstanciadamente sobre sus relaciones con los virreyes (y declara tan enérgicamente que no va a cortarlas). Es evidente que lo que más le ardía a Núñez eran esas visitas de Sus Excelencias.

Decir que, a partir del Neptuno Alegórico - ese arco de doble triunfo: para el nuevo virrey de México y para la monja que al fin revelaba plenamente su talento-, toda la conducta de Núñez para con Sor Juana se explica por la envidia, es decir algo que no puede probarse more mathematico, ni siquiera more philologico. Lo que en 1932 observaba Fernández MacGregor no debe echarse en saco roto: hay en Núñez algo que se llamaba y quizá siga llamándose "deseo de santificación"; pero también pasiones muy humanas. Núñez, como dice su apologista más reciente, "était un homme austère. Il a pu penser que la vie à moitié mondaine de Sor Juana ne lui permettait de faire de vrais progrès dans la vertu et qu'il perdait donc avec elle son temps et même son «image de marque" de confesseur" 84 . En efecto, de haber sido él quien

${ }^{83}$ En 1655 había sufrido con muy poca paciencia un eclipse menos serio. He aquí lo que dice una carta del superior general al provincial, P. Juan del Real (Roma, 30 de enero de 1656): “...A lo dicho añaden que V.R. envió a Guatemala al P. Antonio Núñez, que leía en la.Puebla Moral y Escritura, y acomodó allí al P. Manuel de Benavides, nacido en España. De estas y otras resoluciones, y de algunas palabras que han oído hablar a V.R. con poca estima de los nacidos en esa tierra, coligen, no sin fundamento, que les tiene poco afecto; y si todo esto fuese verdad, lo sentiría yo vivamente, porque podría ser ocasión de discordias y poca unión, y causa de graves daños en esa provincia. Ruego a V.R., por el deseo que siempre he tenido de la paz y observancia, que ataje y apague cualquier centella de desunión y nacionalidad, y castigue severísimamente a los que con obras o palabras se opusieren al espíritu de amor y caridad que es tan propio de nuestra Compañía, y procure consolar a dicho P. Núñez en lo que se pueda, porque está muy desconsolado" (ZAMBRANO, p. 518). Es claro que fue el propio Núñez quien se quejó del agravio. El motivo visible de la queja era lo bastante grave para que el padre general interviniera: meter en el seno de la Compañía los consabidos resquemores criollos por las preferencias dadas a peninsulares era causar "graves daños". Pero la expresión " $m u y$ desconsolado" hace pensar en un motivo menos visible: no era lo mismo enseñar en Guatemala que en la floreciente Puebla de los Ángeles.

${ }^{84}$ BÉNASSY, p. 175. Cf. ibid., p. 227, nota 48: es "muy probable" que el abandono de Pérez de Barcia por Núñez (véase supra, p. 596, nota 11) 
abandonó a Sor Juana y no viceversa, Núñez pudo pensar que estaba perdiendo su tiempo, y hasta eso más precioso, su "image de marque", su fama de gran confesor, de gran hacedor de santos. (De hecho, quien pensó esto fue la propia Sor Juana, como

“ts'explique aussi par un certain autoritarisme: il aurait répugné à voir son pénitent lui échapper partiellement". Llamo "apologista" de Núñez a esta autora porque, aunque muy alejada de la actitud de Fernández MacGregor (actitud que hasta un ultra como Alfonso Junco encontró extremosa), es visible su empeño de reivindicación contra los ennegrecedores de la figura del jesuita, y muy particularmente contra Chávez (a quien, sin embargo, no ataca de frente). Al comienzo de su libro (p. 25) dice que en el México de Sor Juana, "comme en Espagne, peut-être même davantage" (?), se conocen "des formes spectaculaires de pénitence" de índole neurótica, pero que ni esta clase de "piedad" ni tampoco la superstición lo han invadido todo: el P. Núñez "en représente justement l'exacte antithèse"' (obsérvese el énfasis: antithèse es ya término fuerte, y no había mucha necesidad de reforzarlo con justement y exacte). Todo depende, naturalmente, de lo que entendamos por "superstición" y por "formas espectaculares de penitencia". En sentido estricto, no había en el mundo hispano-católico del siglo XVII nadie que fuera la antítesis de la superstición: Núñez, hombre de libros, no habrá compłartido las supersticiones del vulgo, pero escribió y predicó y publicó un sermón para celebrar el extraño milagro de la "reintegración de los panecitos de Santa Teresa" por mano de la venerable Juana Poblete ("Bien molidos, y revueltos en menudo polvo, y arrojados por esta piadosa señora en un vaso de agua, volvíase a consolidar aquella harina formándose de nuevo el mismo panecito de antes..., [con] la misma imagen impresa, con las mismas líneas, rasgos, señales o carácteres con que se avían antes notado", según cuenta JULIÁN GUTIÉRREZ DÁvILA en sus Memorias históricas de la congregación del Oratorio de la ciudad de México, 1736, citado por A. DE ANTUÑANO en RUMex, 1987, núm. 437, p. 53). BÉNASSY, por cierto, cita varias veces ese sermón de Núñez (en la p. 187, nota 5 , habla de "multiplicación" de los panecitos, pero no era eso: cuando Juana Poblete molía ocho panes y hacía las demás operaciones, se reintegraban esos mismos ocho panes; lo que sí dice Gutiérrez Dávila es que, una veź que Santa Teresa, desde el cielo, había operado el milagro de la reintegración, sobraba "no pequeña porción de la harina"). En cuanto a las formas espectaculares de penitencia, eran también fenómeno conocido en todo el mundo católico, y no sólo en el hispano. Núñez mismo, según su biógrafo (cf. PAZ, pp. 586-587), se disciplinaba cada tercer día dándose 73 azotes "en reverencia de los setenta y tres años que vivió la Santísima Virgen..., y los golpes eran tan recios y propinados tan sin piedad, que se oían fuera del aposento, causando lástima y compasión a los que los escuchaban", y temor de que un día "pudiesen encontrarlo muerto" (las puertas y paredes de su cuarto estaban salpicadas de sangre). Sin embargo, aunque admitamos que Núñez no era muy supersticioso, y que sus formas de penitencia no eran muy espectaculares, el hecho es que Sor Juana nos lo presenta en su Carta como un fanático que quiere imponerle a su hija la peor forma de penitencia (la renuncia a sus impulsos naturales), y eso en nombre de una concepción de la vida que Sor Juana, Calleja, Tineo y otros muchos bien hubieran podido calificar de "supersticiosa" (superstitio es, etimológicamente, un 'exceso', una 'exageración'). 
lo dice en la Carta, 281-282: " no soi tan mortificada como otras hijas $^{85}$ en quien se empleara mejor su doctrina'). En suma, la apologista de Núñez admite que éste pudo haberse movido por un sentimiento de vanidad herida. Pero la vanidad es pariente, hermana quizá, de la envidia. Quienes sienten, como dice Sor Juana, que el aplauso dado a otros es "usurpación" del que ellos creen merecer, pueden llamarse indistintamente vanidosos o envidiosos.

Espero que las anotaciones que siguen, sobre aspectos concretos de la Carta, tengan alguna utilidad para el lector.

A] Es bueno comparar esta reflexión sobre el silencio - "juzgando que mi silencio sería el medio más suave...' - con otra análoga que hace Sor Juana en la Respuesta a Sor Filotea. Después de dedicar largos párrafos a ponderar y agradecer la exquisita solicitud del obispo de Puebla, pide en seguida perdón por la "digresión". Lo que ha dicho es ciertamente verdad, pero, "si la he de confesar toda, también es buscar efugios para huir la dificultad de responder, y casi me he determinado a dejarlo al silencio..., [que] explica mucho con el énfasis de no explicar"', etc. (67 ss.). Es la misma táctica que había pensado emplear Sor Juana en el caso de Núñez. En los dos casos tuvo que desecharla, pues "como [el silencio] es cosa negativa..., es necesario ponerle algún breve rótulo para que se entienda lo que se pretende que el silencio diga; y si no, dirá nada el silencio, porque ése es su propio oficio: decir nada"' (Respuesta, 71-75).

B] "No consentí... poner mi nombre". Recuérdese el énfasis con que Sor Juana le dice esto mismo al obispo de Puebla (Respuesta, 204 ss.): "[Desde que me hice monja], sabe el Señor, y lo sabe en el mundo quien solo lo debió saber, lo que intenté en orden a esconder mi nombre, y que no me lo permitió, diciendo que era tentación, -y sí sería'. No contenta con esto, insiste en seguida en el carácter sumamente íntimo de la confidencia (no la haría de no ser Sor Filotea quien es). Largamente se ha declarado abrumada por los "favores" de Sor Filotea, e incapaz de

${ }^{85}$ Hijas, y también hijos. GUTIÉRREZ DÁVILA, para ponderar los quilates de virtud a que había llegado el venerable Pérez de Barcia en materia de mortificación, dice: "Basta decir que [su director espiritual fue Núñez]... para de allí inferir lo que tendría de mortificado; pues, fuera de que el P. Núñez no necesitaba para ello hacerse mucha fuerza, fue singular el cuidado que puso en mortificar a Domingo"' (Vida mencionada supra, p. 596, final de la nota 11). 
traducir en palabras su infinita gratitud: "sólo responderé que no sé qué responder, sólo agradeceré diciendo que no soy capaz de agradeceros"'86; con alusión a esas palabras dice ahora: "Si yo pudiera pagaros algo de lo que os debo, señora mía, creo que sólo os pagara en contaros esto, pues no ha salido de mi boca jamás, excepto para quien debió salir' ${ }^{87}$. Y vuelve a insistir hacia el final (1384-1387): "en lo poco que se ha impreso mío, no sólo mi nombre, pero ni el consentimiento. para la impresión ha sido dictamen propio, sino libertad ajena que no cae debajo de mi dominio" (donde llama la atención ese poco, pues la Respuesta es del $1^{\circ}$ de marzo de 1691, y la Inundación Castálida de 1689). En la Carta es menor el énfasis, por la sencilla razón de que a Núñez le consta la seriedad de aquel antiguo deseo de ocultamiento. Fue Núñez quien contrarió tal deseo, fue él quien le dijo a su hija que era tentación, él quien, sin el "consentimiento" de Sor Juana, puso su nombre en los Villancicos de la Asunción de 1679.

C] Vale la pena comparar este párrafo de la Carta con el comienzo de la "Razón de la fábrica..." (SJ, t. 4, pp. 357-358), donde Sor Juana explica, en 1680 , por qué ha aceptado componer el Arco: "El lucimiento de los arcos triunfales erigidos en obsequio de los señores virreyes que han entrado a gobernar este nobilísimo reino [ha sido hasta ahora] desvelo de las más bien cortadas plumas de sus lucidos ingenios... [Ante] tal asunto, y tan desigual a mi insuficiencia..., [yo me hubiera excusado] a no haber intervenido insinuación que mi rendimiento venera con fuerza de mandato, o mandato que vino con halagos de insinuación'. Es claro que esta explicación iba dirigida a Núñez - lector seguro del Neptuno- para decirle lo mismo que le dice en la Carta: 'No tuve más remedio que aceptar el encargo' (Núñez sabía que esa persona veneradísima de quien venía en última instancia el encargo era el arzobispo fray Payo).

Lo notable en el párrafo inicial de la "Razón de la fábrica..." es la manera sinuosa como procede Sor Juana: tan oblicua como su mención del arzobispo es su explicación de por qué aceptó el

${ }^{86} \mathrm{Cf}$. un juego parecido en la décima dedicada muy poco antes a Castorena (SJ, t. 1, núm. 112): "Favores que son tan llenos / no sabré servir jamás... / De pagarse están ajenos / al mismo agradecimiento', etc.

87 Núñez está muy presente en la Respuesta a Sor Filotea, pero no se le menciona sino por circunloquios. Cf. poco antes (194-197): "le he pedido [a Dios] que apague la luz de mi entendimiento dejando sólo lo que baste para guardar su Ley, pues lo demás sobra, según algunos, en una mujer; y aun hay quien diga que daña"'. Cf. también supra, pp. 635-638. 
encargo: "el Venerable Cabildo", al poner los ojos en "una mujer no conocida, ignorante y pobre", imitó la estratagema de Joab (II Samuel, cap. 14), o sea que procedió “"a imitación de Dios", inspirador de Joab. El papel de la humildísima Tecuites consistió sólo en prosternarse ante un gran príncipe (el rey David) y decirle unas palabras; ella, Sor Juana, ha aceptado a su vez ser el humilde instrumento de la piadosa estratagema del Cabildo. "Por esta razón, pues, o por otra que no debe mi curiosidad inculcar, [acepté el encargo]"'.

Estas últimas palabras son èl colmo de la sinuosidad. Dan a entender que la otra razón bien podría ser la profunda, la auténtica, de manera que todo lo anterior, y hasta el chispeante relato de la Carta, con esos imponentes "señores juezes hazedores" que se presentan en el convento para exigir el cumplimiento de una orden, quedaría como simple razón secundaria, si no como mera ponderación retórica.

Yo creo que no es difícil adivinar esą otra razón, la realmente poderosa. Es claro que, al llamarse "mujer ignorante", Sor Juana pone el pie en el trillado tópico de 'modestia', no para quedarse en él (cf. infra, nota 96), sino sólo para dar desde allí un salto. Es como cuando, en la Crisis del Sermón de Vieira, después de decir que " a vista del elevado ingenio del autor, aun los muy gigantes parecen enanos; pues ¿qué hará una mujer?", reflexiona Sor Juana que "no es ligero castigo a quien creyó que no habría hombre que se atreviese a responderle, ver que se atreve una mujer ignorante, en quien es tan ajeno este género de estudio y tan distante de su sexo" (SJ, t. 4, pp. 434-435). En su jactancioso reto: 'No hay hombre que se atreva a refutarme', ni por un momento pensó Vieira en las mujeres, desconocedoras de las sutilezas escolásticas, ignorantes por definición ${ }^{88}$. Otro buen ejemplo está en la última poesía que escribió Sor Juana, el romance "¿Cuándo, númenes divinos...?" (SJ, t. 1, núm. 51): "A una ignorante mu$j e r .$. / se dirigen los elogios / de los ingenios más claros / que en púlpitos y en escuelas / el mundo venera sabios?' Los elogiadores del Tomo Segundo, representantes de lo más granado de España en ciencias divinas y humanas, no pueden ser tan tontos que canten himnos a la ignorancia. En el salto, la fórmula de modestia ha quedado muy abajo, y lo que hay es un tranquilo reconocimiento: 'Yo admito los elogios que me hacen mis admi-

${ }^{88}$ Ignorante, dicho de una mujer, o de un rústico, era uno de esos epítetos puramente ponderativos, que no añaden nada concreto al sustantivo (como "el blanco jazmín" o "la roja sangre"). 
radores españoles'; 'Yo me mido con el famoso Vieira' ("Mi entendimiento, tal cual, ¿no es tan libre como el suyo, pues viene de un solar?', dice en la Respuesta, 1172-1173). Así, pues, la otra razón, aquella que la curiosidad de Sor Juana se sintió obligada a callar (a "no inculcar"), es seguramente ésta: 'Acepté la invitación del Cabildo porque me daba una espléndida oportunidad de demostrar algo de lo cual estoy íntimamente convencida: que las capacidades intelectuales de las mujeres no son distintas de las de los hombres'.

D] "En el testamento de Sor Juana (23 de febrero de 1669) hay un pasaje conmovedor. En esos documentos las novicias [a punto de profesar: cf. supra, p. 607, nota 36] hacían renuncia de sus bienes, y Juana Inés dice: "Declaro tengo en poder de doña Isabel Ramírez, mi madre, doscientos y cuarenta pesos de oro común en reales, cuya cantidad me dio y me donó el capitán don Juan Sentís de Chavarría ${ }^{89}$ : declárolos por mis bienes». Ésa era toda su fortuna" (PAZ, pp. 152-153). En realidad, la "renuncia" era muy relativa. Los 240 pesos seguían siendo de ella, como lo fueron todos los dineros que ganó después. Sor Juana no le habla a Núñez de los 200 pesos que el Cabildo le pagó por el Arco. En comparación de lo que le habían pagado hasta entonces por sus Villancicos, esta suma debió parecerle colosal: véanse sus décimas de agradecimiento ( $S J$, t. 1, núm. 115), donde dice, en esencia: 'Señores, ustedes me han hecho rica, y eso es peligroso. Con la riqueza, los vuelos poéticos decaen. ¡Cuidado! Sin ir más lejos, estas décimas me saldían mejores si siguiera siendo pobre'. Un hecho perfectamente conocido desde la Vida de Calleja (y corroborado por la documentación descubierta en nuestro siglo) es que Sor Juana acabó por ser verdaderamente rica ${ }^{90}$.

${ }^{89}$ Chavarría fue uno de los ricos más "sableados" por Núñez: véase ZAMBRANO, pp. 527-529 y 537 (y cf. supra, p. 603, final de la nota 25). A su muerte, ocurrida a fines de 1682 , Chavarría les legó a los jesuitas la próspera hacienda de San José Oculman. Poco después de su muerte, según noticia de Oviedo (cf. PAZ, p. 587), Chavarría se le apareció al P. Núñez para hacerle saber que no había estado sino ocho días en el purgatorio. (En cambio, como se habrá visto supra, p. 603, nota 27, el alma de Núñez no estuvo ni un segundo en el purgatorio: voló de la cama al cielo). Núñez dedicó a Chavarría dos elogios fúnebres, pronunciados en sendas fundaciones suyas, y publicados en 1684 (MEDINA, núm. 1317).

${ }^{90}$ Quien por primera vez llamó la atención sobre este punto fue la benemérita DOROTHY SCHONS en sus "Nuevos datos para la biografía de Sor Juana", Contemporáneos, 3 (1929), 161-176. Al morir Aguiar y Seixas (en 1698, tres años después de Sor Juana), las monjas de San Jerónimo reclamaron a 
E] Aparte de las "coplillas" de felicitación u homenaje, esta autobibliografía se reduce a cinco obras: 1) unos Villancicos a la Virgen, publicados sin su nombre: 2) otros Villancicos a la Virgen, publicados con su nombre; 3) el Neptuno Alegórico; 4) una Loa al cumpleaños del Rey, por orden de fray Payo; y 5) otra Loa a lo mismo, por orden de la Condesa de Paredes (no de su marido el virrey). Los primeros Villancicos no pueden ser sino los de la Asunción de 1676, que en efecto se publicaron anónimos -la “pausa de ocho años" (lín. 50) nos lleva a 1668, fecha de la entrada en San Jerónimo-; los segundos son los de la Asunción de 1679, en cuya portada se lee que "escribíalos la M. Juana Inés de la Cruz". (Unos y otros, dice Sor Juana, lín. 55, fueron corregidos por Núñez). En cuanto a las Loas, A. M. P. conjetura plausiblemente que la primera es de 1675 , y para la segunda vacila entre 1681 y 1682 (SJ, t. 3, p. 659). Como el cumpleaños de Carlos II era el 6 de noviembre, y como la Carta parece ser de mediados de 1682 (cf. infra, p. 666, anotación $U$ ), yo diría que la segunda Loa es de 1681. Obsérvese cómo Sor Juana pone - ¿mañosamente? - estas Loas palaciegas entre las “obras no públicas"'. Quiere decir 'no impresas'. Pero lo notable es que se deja en el tintero varias otras obras, en particular la Loa de la Concepción, seguramente anterior a 1680 (cf. SJ, t. 3, p. 651, nota a los vs. 356 ss.), los Villancicos de San Pedro Nolasco, de 1677, los de San Pedro Apóstol, de 1677 también -e impresos-, y quizá también los de la Concepción de 1676 (cf. SJ, t. 2, pp. 365-366). Sucede con esta lista lo contrario que con las del Peregrino de Lope de Vega. Lope le gritaba al mundo: 'Vean ustedes cuánto he escrito'; Sor Juana le dice a Núñez: 'Vea usted qué poco he escrito'. (Sor Juana sabe manejar muy bien el énfasis, y ésta es una de sus formas) ${ }^{91}$.

sus albaceas el pago de 5,768 pesos que el arzobispo les había tomado como préstamo forzado. El grueso de esa suma $-5,271$ pesos y 2 tomines- pertenecía a los bienes de Sor Juana, la cual, según aclaraban las monjas en su demanda, "no hauía traído bienes algunos al tiempo de su entrada y professión, pues hauía conseguido la dote de limosnas que otras personas le hauían dado, conque todo lo que adquirió fue después de religiosa professa, en tiempo de más de veinte y seis años, como es notorio" (p. 166). Dorothy Schons supone, con muy buenas razones, que la fortuna de Sor Juana excedía los 5,271 pesos sustraídos por el arzobispo, además de que en esa cantidad no se incluye el precio de las alhajas y de los libros, los cuales, según parece, se vendieron de mala manera.

91 “"[El Neptuno] y los villancicos a las fiestas de la Assumpción y S. Pedro, con otros papeles, estavan ya impressos", dice Francisco de las Heras en su prólogo a la Inundación Castálida. En la Inundación se reimprimen todas estas obras, salvo los Villancicos de la Concepción de 1676. Si la autobibliografía de 
F] El inciso sobre "las mozas" que no quieren "que otras parescan bien" no está en serie con los cinco que preceden, referentes todos a las envidias provocadas por el "saber". Las monjas jóvenes no pueden señalarse por el saber, pero sí por el "parecer bien". Aquí mismo (lín. 127) no dice Sor Juana que los virreyes hayan aplaudido sus habilidades intelectuales, sino que "se agradaron" de ella. Hay que tener en cuenta que Sor Juana no tuvo reparo en hacer comentarios sobre su propia belleza (cf. "Para leer...", p. 485, nota 121). Núñez, en 1667, conociendo "la discreción y gracia en el hablar de Juana Inés, lo elevado de su entendimiento y lo singular de su erudición, junto con no pequeña hermosura, apresuró su entrada en el convento" (OVIEDO). Esta hermosura, en la mente del santo jesuita, la convertía en un novillo aún más " pingüe", más digno de ser degollado en el altar: cf. las palabras de Núñez supra, pp. 614-615.

G] Esta protesta contra la irracionalidad del mundo - "el aplauso que se convierte en tan pungentes espinas de persecución" - es uno de los temas capitales de Sor Juana. ¿Por qué ella, que pone cuanto está en su mano para vivir una vida normal, de acuerdo con sus capacidades y aspiraciones, ha de vivir entre pinchazos de persecución? Recuérdese el comienzo de la Carta (33-36): "La materia de este enojo... no ha sido otra que la de estos negros versos de que el Cielo tan contra la voluntad de V.R. me dotó". No ha sido otra. Allí está la explicación de los aplausos y del cariño de los virreyes y de todo lo demás. Eso es un hecho. Pero en la frase se mete una ironía de dos vertientes. Pese a que los versos son "cosa indiferente" desde el punto de vista moral (cf. infra, p. 669, hacia la nota 125), cosa ni buena ni mala en sí misma, aquí Sor Juana los degrada con un desvalorativo de larga tradición en la literatura: "estos negros versos" (negros, dice Covarrubias, "es color infausta y triste, y como tal usamos desta palabra

la Carta fuera escrupulosa, deberíamos concluir que las cinco series de Villancicos "atribuibles" según A. M. P. - Asunción de 1677, Navidad de 1678, San Pedro de 1680, Navidad de 1680 y Asunción de 1681 - ya no pueden atribuirse a Sor Juana. TAPIA ${ }^{1}$, pp. 43-44, toma muy en serio el catálogo y quiere sacar conclusiones del hecho de que Sor Juana no mencione cierto "soneto" escrito en 1681 (en realidad es una décima: "En tus versos, si se apura...", SJ, t. 1, núm. 108; también MAZA, p. 38, la llama "soneto"). En tal caso, tampoco menciona Sor Juana dos sonetos -éstos sí sonetos- escritos en el convento: "¿Qué importa al pastor sacro...?" (1676) y "Dulce, canoro cisne..." (1680). Son cosas que no valía la pena mencionar (de minimis non curat praetor). En todo caso, quedan incluidas entre las "coplillas" sueltas que sí se mencionan. 
diziendo negra ventura, negra vida, etc.'): estos infaustos, estos desventurados, condenados, malditos versos (o bien, por antífrasis, estos benditos versos, estos dichosos versos... $)^{92}$. Y aquí entra la otra vertiente de la ironía. El saber hacer versos es don gratuito del Cielo; Dios lo otorga a unos, y a otros no, porque así es su voluntad ${ }^{93}$. Dios se lo ha otorgado a ella, ;pero se ha olvidado de preguntarle su parecer al P. Núñez! Todo se reduce a un 'No hallo a qué inclinarme, si al don del Cielo o a la voluntad de usted', lo cual compendia toda la ironía.

Por otra parte, la reacción normal de la gente ante una buena realización de los dones divinos es la admiración. "Los aplausos y celebraciones vulgares ${ }^{94}$ ¿los solicité?", ha preguntado Sor Juana poco antes (113-114). Está claro que no. Los aplausos vinieron por sí solos. Y la pregunta retórica ha sido precedida de un razonamiento bien desarrollado (92 ss.). Cuando se tiene ese don, es muy frecuente que a ello se junte "motivo de vanidad", y vanidad que puede ser legítima ${ }^{95}$. Pero eso está excluido en su caso.

92 PAZ, p. 634, ve aquí una de las “imperfecciones y descuidos" que a veces se advierten en la Carta: "Es claro que el cielo la había dotado no con «negros versos», sino con la facultad de componerlos", dice. Sí, pero creo que se le escapa la ironía. Cf., en la Respuesta, la exclamación "¡Y que haya sido tal esta mi negra inclinación, que todo lo haya vencido!"' (476-477), y la frase "la en mí dos veces infeliz habilidad de hacer versos", con el larguísimo desarrollo que la sigue (523-735).

93 En la Respuesta cita Sor Juana a San Pablo: “Quid autem habes quod non accepisti? Si autem accepisti, quid gloriaris quasi non acceperis?" Ella conoce perfectamente "el riesgo de los aplausos en la flaqueza humana, que suelen apropiarse lo que no es suyo" y convierten a quienes lo olvidan en "ladrones de la honra de Dios" (por debajo está el "Non nobis, Domine, non nobis, sed nomini tuo da gloriam" del Salmista). Ella, por fortuna, nunca ha sido así: "de mí lo conozco, y reconozco que es especial favor de Dios el conocerlo". Ella está inmunizada contra tan bajas tentaciones (Respuesta, 1360-1378).

94 "Vulgares", o sea del público en general, no sólo de dos o tres personas. Francisco de las Heras, secretario de la Condesa de Paredes, habla en 1689 - como testigo que fue - de la fama que rodeaba a Sor Juana en México y hace una buena observación: "La aura popular sólo convierte en humo luces pequeñas, que a la hoguera grande más la aviva la luz". O sea: tratándose de un gran ingenio, lo que hace el aura popular es enaltecer aún más su prestigio, avivarle su luz a la hoguera. No hay señales de que Sor Juana haya conocido "celebraciones vulgares" antes de su entrada en el convento. Calleja, después de contar cómo Juana Ramírez dejó admirados en el palacio de los Mancera a los cuarenta sabios, prosigue: "Entre las lisonjas desta no popular aura vivía esta discretíssima muger, quando [decidió hacerse monja]".

95 Inmediatamente después de contar el episodio del "triunfo" ante los cuarenta sabios dice CALLEJA: "¿Qué estudio, qué entendimiento, qué discurso y qué memoria sería menester para esto? El lector lo discurra por sí [y 
El don del Cielo, "la facilidad que todos saven que tengo", resulta más bien, contra toda justicia, "motivo de mortificazión". El legítimo halago del aplauso "se convierte en pungentes espinas de persecución": "entre los mismos aplausos que tanto le duelen" a Núñez (porque Núñéz piensa que para ella son pecaminosos lechos de rosas), entreverado en esos aplausos, integrado a ellos, viene el castigo: “¿De qué embidia no soi blanco...?”, etc. Pasaje brillante, de maciza retórica, y muy expresivo de lo que fueron las menudencias de la vida conventual para Sor Juana. Es verdad que aquí el "villano" no es Núñez, sino la gente, y en particular las demás monjas. Sin embargo, Sor Juana dice que "unos y otros" - hombres, mujeres, viejas, mozas - quieren obligarla a ver "conforme a las reglas de su dictamen", y esto se aplica principalísimamente a Núñez. ¿Qué otra cosa es la Carta sino una categórica negativa a ver conforme al dictamen del confesor?

Nueve años después, el recuerdo de estas miserias seguirá vivo en Sor Juana (Respuesta, 506-523): “¿Quién no creerá, viendo tan generales aplausos ${ }^{96}$, que he navegado viento en popa y mar en

aplauda por su cuenta a tan prodigiosa mujer], que yo sólo puedo afirmar que de tanto triunfo quedó Juana Inés (assí me lo escrivió, preguntada) con la poca satisfación de sí que si en la maestra [en la escuelita de Nepantla] huviera labrado con más curiosidad el filete de vna vainica": una poca vanidad, una poca "satisfación de sí" siempre hace falta en la vida. (Y esto nos da una idea de la clase de temas que tocaban en su correspondencia el jesuita madrileño y la monja mexicana. Cf. "Para leer...", pp. 484-485, notas 120-122). -Una de las frasecitas más insidiosas de la carta de Sor Filotea es ésta: “...nuestro sexo, propenso siempre a la vanidad".

${ }_{96}$ Recoger los pasajes en que Sor Juana habla de sí misma con la modestia convencional -'yo, una mujer ignorante', 'mis mal formados borrones', etc. (cf. supra, anotación $C$ )- sería tarea fácil, pero larga e inútil: todo el mundo dice cosas así, y el uso social acaba por convertir las fórmulas de modestia en maneras de exhibirse. Lo notable, en Sor Juana, es la naturalidad con que habla de los aplausos de la gente. Uno de sus más exquisitos romances reflexivos comienza: "Supuesto, discurso mío, / que gozáis en todo el orbe, / entre aplausos de entendido, / de agudo veneraciones, / mostradlo..." (o sea: 'Tu fama, discurso mío, es un hecho; veamos si eres digno de ella: resuélveme un problema que te voy a plantear'). Donde mejor se explaya Sor Juana es en Los empeños de una casa (largo discurso autobiográfico de Leonor, I, 283 ss.): "Decirte que nací hermosa / presumo que es excusado...; celebrada por milagro / de discreción... Inclinéme a los estudios...; era el admirable blanco / de todas las atenciones... Era de mi patria toda / el objeto venerado / de aquellas adoraciones / que forma el común aplauso... Voló la Fama parlera... Víctima en mis aras eran... los coräzoncs de todos... Entre estos aplausos, yo...”, etc. — "¡Pueril orgullo... aquel sentir Sor Juana ser maravilla!', exclama FERNÁNDEZ MACGREGOR, op. cit., pp. 71-72, ante pasajes como éstos. "Mas ¿cómo no sentirlo, tan evidente? Ridículo, a ser falso", replica sensatamente A. M. P., SJ, 
leche, sobre las palmas de las aclamaciones comunes? Pues Dios sabe que no ha sido así"': ha habido muchos áspides de envidia y hostilidad entre las flores, y los más venenosos no son los declaradamente hostiles, "sino los que amándome y deseando mi bien me han mortificado y atormentado más que lo otros con aquel "No conviene a la santa ignorancia este estudio", "Se ha de perder..."", etc. También aquí nos hallamos ante un plurale pro singulari: "los que me han atormentado más"' son uno: el P. Núñez. El paralelismo resalta en los respectivos comentarios finales: "¿Qué me habrá costado resistir esto? ¡Rara especie de martirio donde yo era el mártir y me era el verdugo!' (Respuesta); "Y de todo junto resulta un tan estraño género de martirio qual no sé yo que otra persona aya

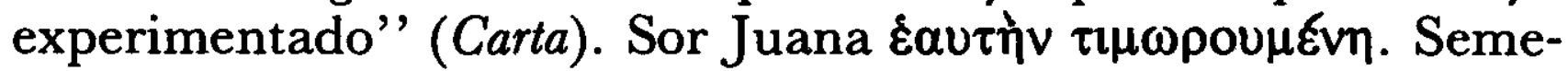
janzas como éstas entre los dos documentos le parecieron "sospechosas" a Octavio Paz en su primera lectura de la Carta: “ ¿cómo era posible tan perfecta y total correspondencia entre uno y otro escrito si están separados por un intervalo de más de diez años?" Pero luego vio que "la continuidad entre los temas [de uno y otro]... es la de la vida misma de Sor Juana"'97. Así es, evidentemente. Basta recordar el más patético de los sonetos que A. M. P. llama "filosófico-morales", el que comienza " ¿Tan grande, ¡ay Hado!, mi delito ha sido...?”, donde Sor Juana, como dice el epígrafe, "muestra sentir que la baldonen por los aplausos de su habilidad": "... Tan severo en mi contra has procedido, / que me persuado, de tu duro intento, / a que sólo me diste entendimiento / por que fuese mi daño más crecido $^{98}$. //Dísteme aplausos, para más baldones; / subir me hiciste, para penas tales...", etc.

t. 1, p. 367. (Cuando en la Respuesta, 1184 ss., dice Sor Juana: " aprecio, como debo, más el nombre de católica... que todos los aplausos de docta", coloca claramente esos aplausos en una categoría inferior, pero con la misma claridad dice que los aprecia).

97 PAz, p. 634. (El intervalo, en realidad, no fue de "más de diez años", sino, según creo haber mostrado, de menos de nueve). "En algunos momentos -dice TAPIA ${ }^{1}$, p. 61 - hemos pensado que cuando Sor Juana escribió, despacio y meditada, la respuesta a Sor Filotea, tenía a la vista en su copiador de cartas la que años antes había escrito a su confesor'. Yo no veo por qué postular semejante "copiador". Pero esa observación suscita una pregunta imposible de contestar: ¿de dónde procede la copia conservada en Monterrey? Resulta difícil suponer que procede directamente del original, o sea de la carta misma que un día de 1682 llegó a manos de Núñez. - Y el texto de la Respuesta que imprimió Castorena en 1700 , ¿ sería copia directa del original? Más aún: ¿la destinaba Sor Juana a la publicidad?

98 Cf. el final del soneto "¡Oh dulces prendas...!” de Garcilaso: "...si no, sospecharé que me pusistes / en tantos bienes, porque deseastes / verme morir 
$H$ ] Sobre las visitas de los "devotos de monjas" véase supra, pp. 611-612. Una monja perfecta, había dicho el P. Núñez en la Plática doctrinal, debe ser como un difunto, que "ni tiene trato humano, ni visita ni es visitado". Las visitas de los virreyes al convento de San Jerónimo ${ }^{99}$ no son la menor de sus desazones. Lo alarman en la misma medida que las actividades literarias. Mejor dicho, no distingue entre lo uno y lo otro. Es muy significativo este non sequitur de Oviedo: es falso - dice- que Núñez "le prohibía a la Madre Juana el exercicio decente de la poesía, santificado con los exemplos de grandes siervos y siervas de Dios"; $y$, cuando esperamos que nos diga: 'lo que sí le prohibía era el ejercicio de la poesía no santificado con esos ejemplos', lo que nos dice es: "estorvábale sí, quanto podía ${ }^{100}$, la publicidad y conti-

entre memorias tristes". (El verso inicial del patético soneto de Sor Juana recuerda el de otro del siempre patético Garcilaso: " $\mathrm{O}$ Oh Hado esecutivo en mis dolores...!'’).

${ }^{99}$ Sor Juana se refiere, naturalmente, al marqués de la Laguna y a María Luisa, su mujer. TAPIA ${ }^{2}$, p. 46 , parece no haber leído bien este pasaje de la Carta, pues dice: "Sor Juana se defiende... diciéndole a Núñez que ella no buscaba las relaciones con los Virreyes de Mancera, que aun se escondía de ellos", etc. También JOSEFinA MURiEL, Conventos de monjas en la Nueva España, México, 1946, p. 257, supone visitas de los Mancera, y JUAN CARLOS MERLO, prólogo a Obras escogidas de Sor Juana, Barcelona, 1968, dice que los Mancera "solían asistir a la capilla [de San Jerónimo] para las oraciones de las vísperas, y luego en el locutorio acostumbraban departir con Sor Juana", noticia aceptada por PAZ, pp. 181-182, pero que no se basa en ningún documento. El virrey Mancera, como se lee después en la Carta (134 ss.), fue asiduo visitante - "entraba quantas vezes quería" - de otros conventos: el de las capuchinas y el de las carmelitas.

${ }^{100}$ Núñez podía ciertamente estorbar las posibles visitas de los Mancera (en los primeros años de vida conventual de Sor Juana), puesto que tenía autoridad espiritual sobre ellos, pero no impedir las de los Laguna. Ningún miembro de la Iglesia, en el orbe hispano-católico de la época, atacaba de frente a los gobernantes. BÉNASSY, p. 46, observa que "le principe des visites de la cour au parloir n'est pas attaqué" ni en el Destierro de ignorancias de Lumbier ni en la Cartilla de Núñez. Parece significativo que la notificación a las monjas de San Jerónimo para que no recibieran visitas (supra, p. 611, nota 43) se haya hecho durante el interregno entre fray Payo y Aguiar y Seixas (la notificación pudo haber sido inspirada o promovida por Núñez). También parece significativo un retoque que hizo fray Miguel de Torres en su biografía del obispo de Puebla. En la $1^{a}$ ed. (Puebla, 1716) dice que a Fernández de Santa Cruz le dolía ver que Sor Juana - tía de fray Miguel- era "visitada de muchas personas, $y$ de las de primera clase". En la $2^{\mathrm{a}}$ ed. (Madrid, 1722), lo que dice es que al obispo le dolía ver "que su buena capacidad la empleaba frecuentemente en el estudio de libros profanos". (Véase, sobre esto, "Para leer...", pp. 504-505). 
nuadas correspondencias de palabra y por escrito con los de fuera". Y Oviedo insiste: "No pelean las letras con la santidad..., pero ¿quién podrá dudar de que, quando... son estorvo [para la perfección religiosa]..., se debe mortificar aun la natural inclinación? Y nadie negará que son estorvo, y grande, en las religiosas, quando ocasionan distracciones y necessitan al trato y conversación (aunque decente) de que se huyó al entrar en la religión". (Podría preguntársele a Oviedo: el que una monja escriba cosas de amores mundanos, pero para sí sola, o para solaz de su comunidad, sin intervención de nadie "de fuera", ¿no sería también estorbo para la santidad?). En la Carta de Sor Juana no hay ese non sequitur: una cosa son los versos y otra las visitas de los virreyes.

I] A primera vista, esta observación de Sor Juana sobre el trabajo que le han costado sus estudios no viene muy al caso. Son cosas que Núñez sabe, y que nada tienen que ver con su "enojo" (Núñez mismo le pagó maestro). Y no son materia polémica: reconoce Sor Juana "que el cursar públicamente las escuelas no fuera decente a la honestidad de una muger"; admite que, "por la misma razón de honestidad', estén excluidas las mujeres de todo cargo público, y hasta encuentra natural que las cosas sean así (conformismo salpicado de ironía): como la "república", o sea la sociedad, "no las ha menester" para funciones que los varones se han reservado, es lógico que no haga caso de algo "que no le ha te servir". "Pero los privados y particulares estudios, ¿quién los ha prohivido a las mugeres?..." Ahora sí, a partir de este pero, entra Sor Juana en materia polémica, ahora sí está redarguyendo a Núñez. Él, gran teólogo, concede a la mujer la misma capacidad que al varón en cuanto a algo tan infinitamente precioso como es la "gracia y gloŕa de Dios"' (la virtud y la santidad), pero se la niega en cuanto a algo tan inferior, tan pedestremente humano como es "la ilustración de las letras".

Creo que aquí nos hallamos en el centro mismo de esa anima intellectualis de Sor Juana cuyo primer explorador fue don Ezequiel Chávez. Su caso personalísimo - su consciencia de los dones de Dios, su amor irrefrenable a los libros, el trabajo que le ha costado el estudio - se le convierte, sin transición, en un "mensaje" de interés general. Para lanzarlo, acude a uno de sus recursos favoritos, la interrogación retórica. La mujer — dice este mensajetiene el mismo derecho a la cultura que el varón, y a toda la cultura (a cuantas "noticias y siencias"' la constituyen). Es injusto, es irracional estorbar su educación.

Nueve años después, toda esta materia - su caso personal uti- 
lizado como "mensaje" general, como llamado de atención a cuantos viven ese momento de la historia de nuestra cultura - llenará páginas y páginas de la Respuesta a Sor Filotea, ahora ya sin preguntas retóricas, sobre todo allí donde Sor Juana protesta por "la suma flojedad en que han dado en dejar a las pobres mujeres" (1018), con un han dado sin sujeto, pero que no puede ser sino "los encargados del gobierno de la república", y, para que los padres de familia no opten por "dejar bárbaras e incultas a sus hijas" (1027), sugiere nada menos que la creación de una Universidad Femenina $^{101}$.

101 Véase el prólogo que el "Grupo Feminista de Cultura" antepone a su edición de la Respuesta a Sor Filotea de la Cruz, Barcelona, 1979. Abunda en errores (Sor Juana aprendió latín a los nueve años; fue "contemporánea del Concilio de Trento", etc.), pero destaca el papel de Sor Juana en la historia del movimiento de liberación femenina. Uno de los aspectos que más llaman la atención en este movimiento es la presión para que un Concilio apruebe mujeres sacerdotes ( $y$, en consecuencia, mujeres obispos y mujeres papas). El discurso de Sor Juana en esta parte de la Respuesta (1033 ss.) va en la misma dirección. Ella se refiere a un solo aspecto del ministerio sacerdotal, la predicación (pero por algo se empieza). El texto sagrado que "la Iglesia" - el cuerpo místico de Cristo en la tierra, el conjunto de los fieles, hombres y mujeresesgrime siempre contra cualquier veleidad en ese sentido es el contundente Mulieres in ecclesia taceant de San Pablo. Pues bien, Sor Juana demuestra punto por punto (y se lo demuestra a un obispo) que ese texto ha sido mal esgrimido por la Iglesia, puesto que $1^{\circ}$, San Pablo mismo aprueba que mujeres experimentadas y bene docentes instruyan a los ignorantes, y $2^{\circ}$, el taceant de marras "cayó sobre lo historial" y no sobre lo doctrinal: San Pablo se refirió allí a una circunstancia de momento. Lo dice Eusebio (y el obispo sabe que el primer recurso exegético para entender un texto ambiguo u oscuro es acudir a la tradición patrística): en los primeros tiempos del cristianismo "se ponían las mujeres a enseñar las doctrinas unas a otras en los templos, y este rumor confundía cuando predicaban los apóstoles y por eso se les mandó callar, como ahora sucede que mientras predica el predicador no se reza en alta voz"', pero sería absurdo concluir que está prohibido rezar en alta voz. ¡A eso tan puramente circunstancial se reduce el famoso Mulieres in ecclesia taceant! Que Sor Juana tomaba totalmente en serio el asunto lo demuestra la lección de filología que aquí intercala (1062-1110). Para interpretar un texto hay que ponerlo en su contexto, atender a lo historial, leerlo filológicamente: "No hay duda de que para la inteligencia de muchos lugares es menester mucha historia, costumbres, ceremonias, proverbios y aun maneras de hablar de aquellos tiempos en que se escribieron". Y la leccioncita termina con un sarcasmo no leve (11121116): "Todo esto pide más lección de lo que piensan algunos que, de meros gramáticos, o cuando mucho con cuatro términos de súmulas, quieren interpretar las Escrituras y se aferran del Mulieres in ecclesiis taceant sin saber cómo se ha de entender". - M.-C. BÉNASSY, "Más sobre la conversión de Sor Juana", $N R F H, 32$ (1983), p. 465, a propósito de los versos en que Sor Juana dice de Santa Catarina: "estudia, arguye y enseña, / y es de la Iglesia servicio...", 
$J]$ "Los privados y particulares estudios ¿quién los ha prohivido a las mugeres?"' En la Respuesta, 908 ss., Sor Juana cita al "venerable" doctor Juan Díaz de Arce, el cual, tras examinar la cuestión en un libro publicado en México en 1648, "resuelve, con su prudencia, que el leer públicamente en las cátedras y predicar en los púlpitos no es lícito a las mujeres, pero que el estudiar, escribir y enseñar privadamente no sólo les es lícito, pero muy provechoso y útil"' 102. Y añade Sor Juana por su cuenta: "No sólo a las mujeres, que por tan ineptas están tenidas, sino a los hombres que con sólo serlo piensan que son sabios se había de prohibir la interpretación de las Sagradas Escrituras en no siendo muy doctos y virtuosos' '103. En la Carta, unas líneas después (168 ss.), rebatirá Sor Juana la posible objeción de Núñez: "que en los hombres milita otra razón".

$K$ ] En la Respuesta, 448 ss., habla Sor Juana de "aquellas cosas accesorias de una religión, como estar yo leyendo y antojárseles en la celda vecina tocar y cantar; estar yo estudiando y pelear dos criadas..., estar yo escribiendo y venir una amiga a visitarme...,

etc., observa que esto "contradice implícitamente al mismísimo San Pablo", y lo explica así: "En unos villancicos cantados ante el pueblo un día de fiesta [y además (hubiera podido añadir) en la lejana Antequera de Oaxaca], es posible introducir -entre veras y burlas - ciertas cosas que serían inconcebibles en un alegato dirigido a un obispo". Por lo visto, no ha reparado bien esta estudiosa en el pasaje de la Respuesta que acabo de comentar, donde Sor Juana, dirigiéndose a un obispo, contradice explícitamente, y muy de veras, no a San Pablo, sino a los ignorantes que durante siglos han malinterpretado el texto paulino (y han elevado a dogma su mala interpretación). Lo que dice en la Respuesta es mucho más atrevido que lo que dice en el villancico. (Además, Santa Catarina argüía y enseñaba a paganos, no a cristianos católicos).

102 Más adelante (1198-1217) recuerda cómo este Dr. Arce habla de dos monjas "que conoció en esta ciudad", las dos de prodigiosa memoria, "y se duele de que tales talentos no se hubieran empleado en mayores estudios, con principios cientificos".

103 “'Así le sucedió el año 1630, en Sevilla, a un predicador... que a pocos sermones que hizo, como eran todos violentados y traía la divina Escritura al redopelo..., le mandaron los señores Inquisidores que no predicara más" (fray TOMÁs RAMÓN, Nueva premática de reformación..., Zaragoza, 1635, citado por "Un rebuscador de papeles viejos" [el travieso P. Miguel Mir, ex-jesuita] en sus Curiosidades de mística parda, Barcelona, 1897, p. 189). Sor Juana debe haber tenido amplias oportunidades de oír sermones idiotas. Véanse en las mismas Curiosidades de mística parda, pp. 191-193, dos casos (referidos por el P. ALEJANDRO PANEL en la dedicatoria de La sabiduría y la locura en el púlpito de las monjas, Amberes, 1747) de predicadores ineptos caricaturizados por monjas dueñas de "una feliz memoria y una gracia especial para remedar". 
y esto es continuamente, porque como los ratos que destino a mi estudio son los que sobran de lo regular de la comunidad, esos mismos les sobran a las otras para venirme a estorbar'. De ahí el "voto" de no perder el tiempo haciendo visitas a otras celdas (ibid., 486 ss.), voto mencionado también por CALLEJA: “...poniéndose preceptos rigurosos de no entrar en celda ninguna, porque en todas era tan bien querida, que no podía entrar a salir presto”. Pero el pasaje de la Carta: “¿Por qué ha de ser malo que el rato que yo avía de [perder en cosas vanas]... lo gastara en estudiar...?" nos hace pensar sobre todo en el final del soneto "En perseguirme, Mundo.." (cf. supra, p. 634, nota 67): "teniendo por mejor... / consumir vanidades de la vida / que consumir la vida en vanidades".

L] "V.R. quiere que por fuerza me salve ignorando". Sor Juana y Núñez sabían tan perfectamente como nosotros en qué consistía este ignorar. Recuérdense las palabras de Núñez: "Deseo mucho... que os aventajéis en todas buenas prendas", etc. (supra, p. 613). Entre las buenas prendas no podía faltar la ilustración religiosa: la lectura de San Jerónimo y los demás Padres y Doctores, por ejemplo. Pero todo el resto de su doctrina eran restricciones, y estas restricciones eran, en su mente, obligatorias. Sor Juana debía eliminar el estorbo de su excesivo afán de leer, debía imitar a San Antonio Ermitaño "con su ignorancia santa" (204). Pero ella dista mucho de ver en eso un precepto: no es sino un consejo bonito que puede ser atendido o no, y que ella, desde luego, no se propone escuchar. Ella no va a seguir el camino de la ignorancia, y menos "por fuerza" (cf. infra, nota 114).

Para que su relación con Núñez hubiera podido continuar, Sor Juana tendría que haberle dicho: 'Querido padre, sus consejos son preceptos para mí'. Habría sido lo hagiográficamente correcto. Es, por cierto, lo que CASTORENA inventa que sucedió a fines de 1690 con la carta del obispo.de Puebla: en cuanto la leyó Sor Juana - dice-, " "luego, luego, por enagenarse evangélicamente de sí misma, dio de limosna hasta su Entendimiento en la venta de sus libros" y adoptó la vía de la santa ignorancia (cf. "Para leer...", pp. 497-499). Fray Miguel de Torres (cf. supra, nota 100) cuenta el mismo cuento: la carta de Sor Filotea tuvo "el deseado efecto" sobre Sor Juana: "retirándose, y aplicando de allí adelante su poema [sic] a cosas espirituales, como se lo persuadía la carta, vivió y murió dando exemplo a sus hermanas...", etc. El consejo del santo obispo fue precepto para ella.

De hecho, Castorena y fray Miguel podían apoyarse en la Res- 
puesta de Sor Juana (117-120): "Recibo en mi alma vuestra santísima amonestación..., que aunque viene en traje de consejo, tendrá para mí sustancia de precepto". Sabemos, sin embargo, que no fue así. Si Sor Juana le hubiera hecho caso al obispo, se habría abstenido de escribir más cosas profanas - cosa que no sucedió: cf. "Para leer...", p. 503- y no habría publicado el Tomo Segundo de sus obras. La declaración de sometimiento fue algo hecho de dientes afuera. ¿Qué otra cosa podía hacer? En la Carta se atreve a redargüir a Núñez ${ }^{104}$; en la Respuesta no puede hacerlo sino muy por debajo del agua. En la Carta, es una religiosa que se pone al tú por tú con un religioso, tal como en la Crisis será un aficionado a la especulación teológica que se pone al tú por tú con otro de su especie. Podría decirse que en la Respuesta es una monja que le habla familiarmente de vos a otra monja ("como a una religiosa de velo, hermana mía", 1422), pero es claro que ni Sor Juana ni Sor Filotea han tomado en serio esta ficción.

$M]$ La frase es algo torpe: no se ve a qué se refiere el su de "repugnante a su natural"'. Sor Juana parece enredarse entre el modo personal y el modo impersonal. Por una parte, "V.R. quiere que por fuerza me salve ignorando", y "[el saber] es camino para mi más suave"; por otra parte, "¿no puede hacerse esto saviendo...? Pues ¿por qué para salvarse ha de ir por el camino... repugnante a su natural?" (hoy diríamos "ha de ir uno [o una] por el camino...'). Sor Juana entrevera su caso particular con el hecho general: da lo mismo decir 'yo soy asî' que 'cada cual es como es'.

${ }^{104}$ El verbo aparece en dos pasajes de la Carta: "[Prefería quedarme callada] y no que pareciera passaba yo la lígnea de mi justo y debido respecto en redargüir a V.R." (13-17); "y pues tomo la pluma, redarguyendo a quien tanto venero, es porque ya no puedo más" (279-280). Redargüir a alguien es desagradable, es inelegante. Sor Juana aborrece los pleitos. La Crisis del sermón de Vieira, le dice a Sor Filotea, "la escribí con más repugnancia que otra cosa", primero por tratarse de algo sagrado, y segundo "porque parecía querer impugnar, cosa a que tengo aversión natural" (Respuesta, 1268 ss.). Tampoco el romance sobre la pasión de los celos, en que "contradice un problema de don José Montoro, uno de los más célebres poetas de este siglo", es fruto de un espontáneo espíritu de contradicción; "no es ni puede ser réplica" del argumento de Montoro (a saber, que el amor perfecto desconoce los celos), "sino sólo una obediencia / mandada de gusto ajeno, / cuya insinuación en mí / tiene fuerza de precepto" (SJ, t. 1, núm. 3, 283-288). Ella está en realidad de acuerdo con Montoro, pero quien le pidió llevar la contra - obviamente la Condesa de Paredes- piensa otra cosa. Muy bien. Pero ¿cómo no admirar el regodeo y la verve con que Sor Juana redarguye a Vieira y a Montoro? 
Hasta aquí, tales declaraciones se han hecho en forma personal: "estos negros versos de que el Cielo... me dotó" (35), "la facilidad que todos saven que tengo" (92), y las líneas 194 ss.: "Dios $m e$ inclinó a esso..." (el "estudio", las actividades intelectuales que Núñez reprueba) ${ }^{105}$, donde están las palabras quizá más atrevidas de toda la Carta: "Yo tengo este genio. Si es malo, yo me hize. Nací con él y con él he de morir". Sor Juana supone que Núñez responde al "Yo tengo este genio" con un 'Pues ese genio es malo', a lo cual ella replica que entonces no hay remedio: ella se hizo así, y no está dispuesta a violentar su natural ${ }^{106}$. Chávez presintió muy bien este pasaje de la Carta. Hablando del año "crítico" de 1693, ve a Sor Juana "venciéndose a sí propia, en el trágico duelo que en su conciencia se libraron los dos conceptos de vida mejor que toda su vida tuvo a la vista: ...el propio suyo, que

${ }^{105}$ Cf. lo que dice Sor Juana en el romance "Estos versos, lector mío..." (que constituye el prólogo al lector de la Inundación Castálida), vs. 17-20: "No hay cosa más libre que / el entendimiento humano; / pues lo que Dios no violenta, / ¿por qué yo he de violentarlo?"

106 Por genio hay que entender, naturalmente, la índole de cada ser humano. Cf. lo que dice Sor Juana en la Respuesta $(271,276)$ sobre las "cosas repugnantes a mi genio" y "las impertinencillas de mi genio". La empresa de refutar a Vieira "iba contra mi genio" (ibid., 1290), como también la empresa de contradecir a Montoro: "Confieso que de mejor / gana siguiera mi genio / el extravagante rumbo / de tu no hollado sendero" (vs. 289-292). Cf. también Respuesta, 751 ss., sobre lo que se aprende en el libro del mundo: “... De las mismas personas con quienes hablaba, y de lo que me decían, me estaban resaltando mil consideraciones. ¿De dónde emanaría aquella variedad de genios e ingenios, siendo todos de una especie? ¿Cuáles serían los temperamentos y ocultas cualidades que lo ocasionaban?" -Ante la frase "Si es malo, yo me hice", se pregunta TAPIA ${ }^{2}$, p. 25, si no diría el texto original "yo no me hice". Yo creo que su hipótesis arruina el sentido de la frase. Sor Juana es responsable de sí misma. - La frase "Yo tengo este genio... y con él he de morir", irresistiblemente me hace pensar en la que Don Quijote le dice al capellán de los Duques (II, 32): "Caballero soy, y caballero he de morir" ("Caballero andante he de morir", ha dicho también antes, II, 1). Y tengo la impresión de que la réplica toda del ingenioso hidalgo al antipático eclesiástico estaba, quizá inconscientemente, en la cabeza de Sor Juana a la hora de escribir la suya. Algunas expresiones de Don Quijote, y mucho de su tono, de su énfasis, afloran en la Carta a Núñez. Por ejemplo: "El lugar donde estoy... y el respeto que siempre tuve y tengo al estado que vuesa merced profesa, tienen y atan las manos de mi justo enojo"; "...vuesa merced, de quien se debía esperar antes buenos consejos que infames vituperios"; "... a lo menos, el haberme reprehendido en público y tan ásperamente ha pasado todos los límites de la buena reprehensión"; "...dígame vuesa merced: ¿por cuál de las mentecaterías que en mí ha visto me condena y vitupera...?” (cf. Carta, 86-88: “...dígame V.R.: ya que en su opinión es pecado hacer versos, ¿en quál de estas ocasiones ha sido tan grave el delicto de hacerlos?"). 
para ella era el natural y fácil..., y el del P. Antonio, modo para ella violento, antinatural y difícil"' (CHÁVEZ1, p. 401).

Al final de la Carta vuelve Sor Juana a la expresión generalizadora: en el cielo hay "infinidad de manciones para diversos genios" (291). Chávez habría gozado al leer esto, él que a propósito de las dos vías, la de Núñez y la de Sor Juana, había citado la frase evangélica (Juan, 14:2) "Muchas moradas hay en la casa de mi Padre”.' (CHÁVEZi, p. 376).

$N]$ El libre albedrío - la facultad de hacer cada uno sus decisiones en materias de moral- es un "don" que Dios ha otorgado a todos los seres humanos, y Sor Juana no está dispuesta a hacer renuncia de él. Núñez no tiene sobre ella más dominio que el que ella, libremente, por "amor" a él, le ha permitido tener. Cf. en cambio las palabras de Núñez, supra, pp. 612-613: "la religiosa renuncia a su propia voluntad y libre albedrio"; al profesar, no queda "en nada suya, ni aun en el albedrio".

o] Los "summos deseos y solicitudes" de Núñez habían tenido esplendorosa publicidad el día de la profesión de Sor Juana (24 de febrero de 1669). “"CCorrió] la fiesta de este día por cuenta del Padre, quien procuró se hiciesse con la mayor solemnidad possible, sin perdonar a gasto alguno, combidando para la fiesta a lo más granado e illustre de los Cabildos ecclesiástico y secular, sagradas religiones [miembros de las distintas órdenes religiosas masculinas] y nobleza de México, y él mismo, la víspera de la professión, sin atender a su mucha authoridad, se puso a componer por sus manos las luminarias" (OVIEDO). Este detalle de las luminarias ha conmovido a más de un sorjuanista ${ }^{107}$. Pero, visto

107 Siempre sorprende encontrar muestras de "humanidad" en una persona rígida, austera, eminente. Es curioso el papel que tuvo Núñez en la publicación del Sermón panegírico en la fiesta titular de los Cinco Señores, Jesús, María y Joseph, Joachín y Ana (México, 1689), obra del P. Manuel Valtierra, jesuita. Éste, "obligado por la obediencia", había predicado "casi improvisadamente" el sermón en la iglesia de la Compañía en Puebla (el predicador designado estaba enfermo). Entonces el Santo Oficio de México le mandó pedir copia, y "pasado el tiempo le llegó al P. Valtierra un paquete y una carta del P. Antonio Núñez de Miranda (que era calificador del Santo Oficio) diciéndole que, como el Tribunal no había encontrado qué tildarle al sermón, él se lo mandaba dado a la estampa, para que volase con la ejecutoria favorable de su doctrina"' (ZAMBRANO, pp. 529-530). ¿Qué grata sorpresa para el P. Valtierra! Es, por cierto, lo que un año después hará el obispo de Puebla con la Crisis 
con los ojos de zorro viejo de un fray Luis Tineo (cf. supra, pp. 630 ss.), no es sino indicio de la esencial “mundanidad" de Núñez. Quien se lucía en esa gran fiesta era el sacerdote que había conseguido degollar tan pingüe novillo.

En todo caso, las expresiones de amor y gratitud abundan en la Carta: "cariños y agasajos muchos que reconoceré eternamente" (222), "padre mío y mi señor" (84), "amado padre mío" (198), "padre amantíssimo" (208), "una persona que con tanta veneración amo y con tanto amor reverencio y estimo" (257), "a quien tanto venero" (280), "summa veneración y filial cariño" (14), " mi amor, mi obligación y mi respeto" (32), "mi amor y reverencia" (276); "es mui proprio de el amor obedecer a ciegas" (44); "el dominio [sobre mi persona] que mi amor le daba y le dará siempre" (212). Estas declaraciones tienen todos los visos de la sinceridad $^{108}$. Sor Juana - dice CHÁVEZ1, p. 394- voló libremente "por más que tan sinceramente ansiase siempre subordinarse con la más dulce y confiada sumisión" a su director espiritual. Es casi lo que dice Sor Juana al final de la Carta (303 ss.): "Si como Nuestro Señor inclinó a V.R. con tanto amor y fuerza mi voluntad conformara también mi dictamen, [mi guía espiritual] no fuera otro que V.R."

$P]$ Era natural suponer que fue Núñez, gran "sableador" de ricos, quien le sacó al capitán Velázquez de la Cadena la importante suma de la dote de Sor Juana ${ }^{109}$. La revelación que ella hace obligará a modificar, en lo sucesivo, el enfoque de esta importante cuestión que es la entrada de Sor Juana en el claustro. Parece que Velázquez de la Cadena, personaje poderoso -en 1654 era secretario de Gobernación y Guerra del virreinato, y seguía siéndolo en tiempos de Mancera-, estaba emparentado con los medios hermanos de Sor Juana (cf. A. M. P., SJ, t. 1, p. 428). Pero no

de Sor Juana. (Núñez era devoto de los "Cinco Señores". Dice OviEdo que, al hacer los montoncitos de pan en el hospital de los locos, iba diciendo: "Toma, Señor Jesuchristo", "Toma, Señora Santíssima María", "Toma, Señor San Joachín", “Toma, Señor San Joseph"; "Toma, Señora Santa Ana”).

${ }^{108}$ Tal vez más que las expresiones parecidas de la Respuesta a Sor Filotea, $\tan$ protocolarias: "vuestra doctísima, discretísima, santísima y amorosísima carta" (6-7), "vuestra venerable persona y excesivos favores"' (214), etc.

${ }^{109}$ Conseguir padrino, dice BÉNASSY, p. 76, no debe haber sido difícil para "une jeune fille vraiment "intéressante", dont, qui plus est, la candidature était soutenue par un homme aussi influant que le P. Núñez"'. Cf. asimismo PAZ, p. 155. La dote de las monjas de San Jerónimo era de 3,000 pesos (J. MURIEL, Conventos de monjas..., p. 254). 
fue este leve -y dudoso- parentesco lo que hizo que el señor capitán se interesara en Juana Ramírez. El texto de la Carta, desde la lín. 206, va así: 'Usted anda diciendo que, a saber que yo había de hacer versos, no me habría metido en el convento; pero si estoy aquí es porque yo lo quise, y la prueba es que, cuando usted y yo nos conocimos, ya mi padrino el capitán tenía ajustado el dinero de la dote, listo para cuando se necesitara; y, cosa digna de refle- . xión, lo que me sirvió para agenciar tal padrinazgo fue eso mismo que usted condena: el hacer versos': "lo tocante a la dote... [me lo habían] ajenciado ${ }^{110}$ estas mismas prendas en las quales, y no en otra cosa, me libró Dios el remedio" ("estas mismas prendas", "estos negros versos de que el Cielo tan contra la voluntad de V.R. me dotó", como se lee al principio de la Carta). Velázquez de la Cadena, en efecto, entendía de versos. En 1654 había sido uno de los jueces del Certamen de la Universidad en honor de la Inmaculada (A. M. P., loc. cit.).

Pero hay algo más, digno de ser subrayado: "quando [me hice monja], avía mui poco que yo tenía la dicha de conocer a V.R" (213); lo de la dote estaba asegurado "mucho antes de conocer yo a V.R." (216). Esto coincide muy fielmente con lo que dice OVIEDO: Núñez "maduró y abrevió quanto pudo aquesta entrada" en el convento. No dejó que la idea madurara por sí sola, ni esperó a conocer un poco mejor a la muchacha, sino que abrevió el proceso hasta el máximo, y, en vez de que Juana escogiera dónde refugiarse, fue él, dice también Oviedo, quien "escogió entre todos el exemplaríssimo y observantíssimo monasterio de carmelitas descalzas"', donde Juana entró como novicia en agosto de 1667 (y de donde salió tres meses después, dizque por razones de salud: evidentemente porque aquello no iba con su ideal de vida). A pesar de que Juana había estado en palacio durante dos años o tal vez más como criada de la virreina ${ }^{111}$, y a pesar de que Núñez

${ }^{110}$ La construcción "lo tenía ajustado mi padrino... y ajenciádomelo estas mismas prendas..." parece algo violenta. Cf. supra, 58-59: “... avérmelo pedido tres o quatro vezes, y tantas despedídome yo" ( = 'y haberme despedido yo...'). Es seguramente una coquetería literaria (como los ya mencionados aína y norabuena). Cf. Cervantes, Quijote, I, 30 (ed. cit., t. 2, p. 404): Don Quijote le dice a la princesa Micomicona que se propone tajarle la cabeza al gigante Pandafilando, "y después de habérsela tajado y puéstoos en pacífica posesión de vuestro estado...", etc. Y La española inglesa (Novelas ejemplares, ed. J. Rodríguez Luis, Madrid, 1983, t. 1, p. 283): “...a conocerme los turcos por aquel que había echado a fondo sus bajeles y quitádoles de las manos la gran nave de la India...", etc.

${ }^{111}$ No sabemos cuánto tiempo estuvo Sor Juana en el palacio de los Mancera. Según el testimonio del marqués, recogido por CALLEJA, cuando Juana 
"como confessor de los señores virreyes entraba a menudo en palacio" - testimonio de OVIEDO; y cf. la Carta misma, 130-134-, las palabras de Sor Juana obligan a situar su fatal encuentro con el jesuita hacia mediados de 1667. (Núñez era confesor de los señores virreyes, pero no de la gente menuda de palacio). En todo caso, queda claro que la idea de hacerse monja no era ninguna veleidad. Fue un paso largamente meditado.

Q] Tanto en la Respuesta como en la dedicatoria del Tomo Segundo de sus obras se duele Sor Juana de no haber tenido maestro (cf. "Para leer...", pp. 489-490). Lo dice también en la Carta, 147-148: "no me he valido ni aun de la dirección de un maestro, sino que a secas me lo he avido conmigo y mi trabajo". La única excepción fue el maestro de latín, o sea el bachiller Martín de Olivas ${ }^{112}$, que con razón merece un lugar importante en la historia intelectual de Sor Juana. Es el único favor concreto de Núñez que Sor Juana agradece. Ella le dedicó un bonito soneto, publicado en el Tomo Segundo, cuyo epígrafe dice: "Acróstico que escribió la Madre Juana a su maestro, el Br. Martín de Olivas". Olivas escribió a su vez un soneto a la muerte de Sor Juana, publicado por Castorena (Fama, p. 174) con este epígrafe: "Justíssimo dolor que en la muerte de la Poetisa expressa mudo el Bachiller D. Martín de Olivas, presbytero, maestro que mereció empezar a ser de la Poetisa (y no fue menester proseguir) en la lengua latina". CALLEJA dice: "Solas veinte lecciones de la lengua latina testifica el Bachiller Martín de Olivas que la dio, y la supo con eminencia". Y Sor Juana (Respuesta, 254-255): "Empecé a deprender gramática, en que creo no llegaron a veinte las lecciones que tomé".

La Carta aporta sobre este punto una precisión importante. Tanto Calleja como Sor Juana, inmediatamente después de mencionar las veinte lecciones (o menos de veinte), pasan a describir la lenta tarea del estudio, el cortarse el pelo "cuatro o cinco dedos" cada vez que, por torpe, no había aprendido algo en determinado plazo, y el abstenerse de queso, etc. (cf. "Para leer...', pp. 478479 y 492). Las palabras de Sor Juana ("Sucedía que... el pelo

se lució ante los cuarenta sabios tenía "no más que diez y siete años" (cumplió los 17 en noviembre de 1665). Estando en palacio escribió evidentemente el soneto a la muerte de Felipe IV (“¡Oh cuán frágil...!”), de 1666, la más antigua de sus composiciones fechables.

112 PAz, p. 636, se olvida de él cuando comenta: “¿Maestro de qué? Probablemente de teología". 
crecía aprisa y yo aprendía despacio, y con efecto le cortaba en pena de la rudeza') sugieren un tiempo bastante largo de aprendizaje. La Carta, sin embargo, nos hace ver que esto no puede referirse al aprendizaje del latín, sino al estudio en general durante la época premonástica. Como Núñez pagó el maestro, y como su encuentro con Sor Juana fue muy tardío (cf. la anotación anterior), las lecciones de latín han de situarse en los pocos meses que precedieron a la entrada en el convento de carmelitas. No hubo tiempo para más. Las palabras galantes de Castorena encierran una verdad: "no fue menester proseguir", pues es un hecho que veinte bastaron; el $\mathrm{Br}$. Olivas "mereció empezar a ser [maestro] de la Poetisa", pues ella se encargó, como pudo, de proseguir lo empezado.

$R]$ “ ¿Soi por ventura herege?" La pregunta es retórica, pero nada trivial. Todo eso que anda diciendo Núñez en los corrillos de la ciudad equivale a una acusación de herejía ('El camino que ha tomado la Madre Juana no es el de la salvación; ruéguenle ustedes a Dios que se convierta'), y una acusación de herejía es lo peor que puede ocurrirle a un católico. Recuérdese la famosa declaración de Sor Juana: "yo no quiero ruido con el Santo Oficio" (Respuesta, 177). Si se ha decidido a escribir su Carta a Núñez, es para replicar: 'Yo no soy ninguna hereje; no me he apartado del redil católico'.

Años después, al publicarse la Crisis, cierto anónimo censor la acusó positivamente de "herética". Pues bien, pese a apreciar "más el nombre de católica... que todos los aplausos de docta" (Respuesta, 1184-1187), esa vez Sor Juana decidió contestar con el silencio, cuyo oficio es "decir nada" (cf. supra, anotación $A$ ); esa vez no experimentó el impulso a defenderse, impulso tan vivo y elocuente en la Carta. Todo lo contrario. La actitud que ante aquel asunto muestra la Respuesta no puede ser más desdeñosa: quien anda acusándola de hereje por toda la ciudad (haciendo él mismo copias y más copias de su nauseabundo libelo) no es Núñez, sino un loco de cuyo nombre más vale olvidarse; no será ella quien le haga caso ${ }^{113}$. Pero si el obispo de Puebla la invita a escribir algo pro seipsa, ella lo hará de mil amores: "al menor movimiento de

113 "Yo... no he querido responder"; son otros los que se han tomado la molestia de hacerlo, "sin saberlo yo", y han escrito "papeles"' en defensa suya, de los cuales - añade - "he visto algunos"; o sea que ni siquiera ha tenido la curiosidad de reunirlos todos, de armar un expediente. Cf. "Para leer...", pp. 502-503, nota. 
vuestro gusto cederá (como es razón) mi dictamen, que... era de callar" (1318-1322). Su "dictamen" ha sido encogerse de hombros, o, dicho en lenguaje piadoso, sufrir el golpe con cristiana paciencia, - gran virtud, hermana del estoicismo de los antiguos; "la paciencia vence tolerando y triunfa sufriendo".

Basta ver lo que Sor Juana dice al comienzo de la Carta (1320) sobre la "christiana paciencia" para medir la diferencia. Lo que se oye en toda la Carta es el crujido que produce el sostén de la tolerancia al quebrarse por no resistir más. "¿Soi por ventura herege? Y si lo fuera, ¿avía de ser santa a pura fuerza?" ${ }_{114}$ Las preguntas retóricas se complementan una a otra, y producen una declaración de notable atrevimiento: 'Ciertamente no soy hereje, pero, si lo fuera, no sería la fuerza lo que me haría regresar al redil católico', sino “la razón” (lín. 246).

$S]$ Aquí culmina la recriminación fundamental de la Carta, expresada desde el comienzo mismo (lín. 8): Núñez proclama por toda la ciudad que el caso de Sor Juana es un escándalo público; Núñez la "desacredita" y la pone "en concepto de escandalosa

114 Este "tema" de la pugna entre la razón y la fuerza reaparecerá seis años después, memorablemente, en la Loa del Divino Narciso (SJ, t. 3, vv. 202 ss.). El Celo y la Religión traban batalla contra el Occidente y la América (el Celo representa a los conquistadores y la Religión a los evangelizadores; el Occidente y la América representan una sola cosa; su geminación obedece a razones de simetría escénica), y el resultado de la batalla es el que todos sabemos. “¡Ríndete, altivo Occidente!”, dice la Religión, a lo cual contesta el Occidente: "Ya es preciso que me rinda / tu valor, no tu razón" (la evangelización está aún por hacerse). En seguida, la Religión detiene el brazo del Celo, que a punto está de dar muerte a la América: "... vencerla por fuerza / te tocó; mas el rendirla / con razón, me toca a mí"'. Pero la América y el Occidente son altivos y no se entregan así como así. Conservan intacta su dignidad, su consciencia de sí mismos: "pues aunque lloro cautiva / mi libertad, mi albedrío / con libertad más crecida / adorará mis deidades", dice la América (sobre el libre albedrío véase supra, anotación $N$ ); y el Occidente declara que sigue adorando en su corazón al gran Huitzilopochtli, "[pues] no hay fuerza ni violencia / que a la voluntad impida / sus libres operaciones" (compárense estas palabras con las citadas supra, nota 105). Eso de "ser santa a pura fuerza", que con tal energía rechaza Sor Juana, no le parecía mal a su contemporáneo Sigüenza y Góngora, tenido por uno de los pioneros del pensamiento moderno en México. Entre sus edificantes historias de monjas del convento de Jesús María, incluye Sigüenza (Parayso occidental, 1684) la de Sor Tomasina de San Francisco; después de contar punto por punto las sádicas torturas a que su madre la sometía, comenta: "A mi ver, procedía esta señora inculpablemente, por hazerlo para que su hija fuese muy santa" (citado por BÉNASSY, p. 49; cf. también FERNANDO BENÍTEZ, Los demonios en el convento, México, 1985, pp. 58-60). Sobre hacerse santo a pura fuerza véase también supra, anotación $L$. 
con todos"; en cuanto tiene oyentes, suelta una tarabilla de "vituperios" (225) y condena sus lecturas (179) y sus versos (87). Anda diciendo (nuevo subrayado, nueva cita literal): “A saber que Juana Inés había de hacer versos, no la hubiera entrado religiosa, sino que la hubiera casado" (207). Siendo enorme la "authoridad" de Núñez, enorme es también el daño que ella sufre en su crédito (24): las almas piadosas están consternadas por esas noticias tan poco edificantes ${ }^{115}$, y el mundo en general está "escandalizado".

Pero en este pasaje culminante, además de reprocharle a Núñez el hacer en público lo que no debe hacerse sino de persona a persona, añade Sor Juana una consideración muy grave: cuando la gente oye cuentos, "cada uno siente como entiende". Es claro que Núñez decía que era malo que los virreyes entraran en el convento de San Jerónimo, puesto que Sor Juana le replica que el virrey Mancera entraba en los de capuchinas y teresas "sin que nadie lo tuviesse por malo" (137). Ese concepto, malo, quedaba entregado a la interpretación de los oyentes; cualquiera podía entender lo peor. Y no sólo "cada uno siente como entiende", sino que también "habla como siente". Sor Juana se abstiene, naturalmente, de escribir la palabra chisme o la palabra calumnia, pero lo que describe tan lacónica y eficazmente es el mecanismo del chisme y de la calumnia.

"Yo de mí puedo asegurar que las calumnias algunas veces me han mortificado, pero nunca me han hecho daño", dirá más tarde (Respuesta, 1352 ss.). ¿Tampoco, según eso, las habladurías promovidas por Núñez "le hicieron daño"? Aquí, creo yo, hay que tomar en cuenta unas palabras del comienzo de la Carta (10-12): "no soi tan absoluto dueño de mi crédito que no esté coligado con el de un linaje que tengo y una communidad en que vivo". Las habladurías están causando daño en otros, no precisamente en ella. Se adivinan los comentarios de quienes prestan oído a los chismes: ‘¡Cómo! ¡la hija de Isabel Ramírez!', etc. ${ }^{116}$, o bien:

115 En la lín. 75, he dudado si dedificados es errata por desedificados; pero bien puede tratarse de una formación con de- privativo + edificados (cf. decolorados, deformados, etc.).

116 TAPIA ${ }^{2}$, p. 34 , cree que "un linaje que tengo" significa 'yo nací noble', - "afirmación de la que no alcanzaremos a dar una prueba genealógica, pero allí está". No se ve que Sor Juana afirme tal cosa. Obviamente, su linaje no es sino su 'familia'. Diego Ruiz Lozano, medio hermano suyo, "recuerda, al testar, "el mucho cariño y buena hermandad" que reinó entre todos los hijos de Isabel Ramírez; y de ello hay otras pruebas"' (A. M. P., $S J$, t. 1, p. 544, nota al núm. 196). Piénsese en la punzante defensa que hizo Sor Juana de su padre, a pesar de que no fue hombre "honrado" ( $S J, \mathrm{t} .1$, 
‘Ese convento de San Jerónimo está echado a perder!' Si ella fuera un ente aislado, sin ligas con una familia temporal y una familia espiritual, "un acto sencillo de paciencia"' bastaría para convertir en "provecho" el sufrimiento de la calumnia (cf. Respuesta, 1374-1375).

T] La enérgica declaración de que " ni en lo espiritual ni temporal" ha corrido nunca Sor Juana por cuenta de Núñez ${ }^{117}$ ha sido como preparada por otras dos, encubiertas en ropaje de preguntas retóricas: “¿Quál era el dominio directo que tenía V.R. para disponer de mi persona...?” (211) y “ ¿Tócale a V.R. mi correpción...?" (241). La primera de estas preguntas va precedida, a su vez, de un paréntesis cargado de sentido: si no fuera tan urgente su reclamación, ella no la haría (escribe "forzada y con vergüenza'), y urge que esto quede claro: ' Yo fui la que me entré monja, no me entró usted; la decisión fue en todo mía' ${ }^{118}$. La otra pregunta añade una enumeración de razones que podrian justificar a Núñez en sus exigencias: "obligación, parentesco, crianza, prelacía o tal que cosa" ('o alguna otra razón de este tipo'). Pero ninguna de las cuatro hipotéticas razones corresponde a los hechos: 'Usted no es responsable de mí; usted no es mi padre; usted no me crió; usted no es mi prelado'. Es Núñez, unilateralmente, quien se declara su padre (253: "ya que V.R. ha dado en ser mi padre"). La santidad es cosa "que se persuade, no se manda; y si se manda, prelados he tenido que lo hicieran", pero ni las altas autoridades ni la superiora de San Jerónimo, sus verdaderos prelados (cf. 52, $62,125,139)$, se oponen a lo que ella hace. Aquí, como en toda la Carta, Sor Juana se desentiende olímpicamente de la doctrina nuñeziana que hemos visto supra, pp. 611-615. Si hay monjas dispuestas a aceptar el "dominio directo" del padre espiritual, con su pan se lo coman; ella no es "tan mortificada" (281).

núm. 95). Esto hace ver mejor la fuerza de otra expresión que se halla al comienzo de la Carta: en el momento de iniciar una defensa de los versos -muchos "santos y doctos" los hicieron-, Sor Juana se interrumpe: "no quiero intrometerme a su defenza, que no son mi padre ni mi madre".

117 A estas alturas, la cosa es bien clara: los 3,000 pesos de la dote se los agenció ella por cuenta propia, y por cuenta propia ha dado los pasos que cree conducentes a su salvación eterna. En las dos esferas de la vida es independiente.

${ }^{118}$ El capítulo en que OviEDo se ocupa de Sor Juana lleva este título triunfal: "Dase noticia de la Madre Juana Inés de la Cruz, a quien hizo religiosa el P. Antonio"'. 
$U]$ "'Rebozan ya en el pecho las quejas" acumuladas durante dos años, $\mathrm{y}$ " "pues tomo la pluma..., redarguyendo a quien tanto venero, es porque ya no puedo más". Estas palabras finales de la apología - lo que sigue, a partir de la lín. 283, no es sino la despedida - corresponden fielmente al párrafo inicial de la Carta. Pero el párrafo inicial es sinuoso y tímido, oscilante entre el 'tengo que tomar la pluma' y el 'prefiero no hacerlo'. Ahora, en cambio, el lenguaje es directo. Los debates interiores han dejado de existir; la "defensa" (10), el "redargüir"' (17), el "responder" $(26,31)$ ya están escritos; el horror ante la idea de llevar una vida de "desesperación" (234), de "exasperación" (244), está ya conjurado. No hay ahora preguntas retóricas. El curioso plural del comienzo, "Aunque ha muchos tiempos...", parece denotar a la vez los dos años que Sor Juana se ha aguantado y las muchas ocasiones en que ha sabido los vituperios que Núñez anda diciendo.

El enojo de Núñez data del Neptuno Alegórico, o sea de fines de 1680. La Carta, según esto, sería de fines de 1682. Pero, como toda ella está compuesta en tonalidad enfática, bien podemos suponer que el doloroso silencio no llegó a los dos años justos. Las palabras "rebozan ya en el pecho..." hacen pensar en las de la Respuesta, 288: "reventaba como pólvora". Ciertamente Sor Juana no era de temperamento flemático. (Sobre el de Núñez véase supra, p. 638 , nota 79 ).

V] El sentido de "al cielo hacen muchas llaves" es claro: 'bien dicen que para el cielo hay muchas llaves' (la de la "santa ignorancia" no es sino una de tantas). Es lo mismo que en seguida dice Sor Juana: en el cielo hay "infinidad de manciones" (cf. supra, p. 658, final de la anotación $M$ ). Tapia lee "del cielo hacen muchas llaves", pero el manuscrito dice " ael cielo". PAZ, p. 645, imprime "que del cielo hace muchas llaves", tal vez por errata, pues en la cita de la p. 635 se lee hacen.

X] Al ser “abandonada” por Núñez -dice BÉNASSY, p. 175 -, Sor Juana se vio "condamnée à se trouver un autre confesseur moins sévère et, malheureusement pour elle, moins intelligent, selon toute probabilité"'. Es como si hubiera presentido las palabras de Sor Juana, la cual, tal vez no sin ironía, admite que ese otro confesor, elegido "libremente" por ella (302) tras abandonar al primero, no va a ser ciertamente " $\tan$ discreto, tan docto y tan santo" como Núñez.

Se sabe, por lo demás, quién fue el nuevo confesor: en la Vida del Venerable Padre D. Pedro de Arellano y Sossa, sacerdote y primer prepó- 
sito de la congregación del Oratorio de México, escrita por Juan José de Eguiara y Eguren (México, 1735), se afirma categóricamente que el sucesor de Núñez fue este $P$. Arellano ${ }^{119}$, tres años menor que Sor Juana, hijo espiritual de Núñez, que con otros dos sacerdotes, el P. Juan de la Pedroza (también oratoriano) y el $\mathbf{P}$. Domingo Pérez de Barcia (también hijo espiritual de Núñez), formaba un trío que tenía edificadísima a la ciudad de México. Corría este dicho: "Humildad, la del P. Pedroza; obediencia, la del P. Barcia; amor, el del P. Arellano"'. Sor Juana, atenta observadora de la "variedad de 'genios" (cf. supra, nota 106), "se explicaba" -dice Eguiara - con esta otra comparación: "Docto el P. Barcia ${ }^{120}$, santo el P. Pedro", declarando así "las especies que recibía de aquellos dos hombres... y concediendo al extático Arellano $^{121}$ las más claras de la santidad, aun viéndolas tan ilustres en el no menos contemplativo Barcia'. Que Sor Juana tuvo buen ojo, lo demuestra el que los diez años que siguieron a su ruptura con Núñez sean los de su pleno florecimiento literario. Transfiriendo a Arellano el elogio que José Mariano Dávila hizo en 1856 de Núñez (cf. supra, pp. 594-595), podemos bendecirlo por no haber violentado la "inclinación a las letras humanas" de la monja, por haberla dejado morar en el Parnasc mientras él vagaba por el Oreb de su propia vida contemplativa.

119 El texto de Eguiara (reproducido por MAZA, pp. 295-296) tiene un error visible. Dice que Sor Juana "se confesó muchas veces con nuestro D. Pedro", y que esto ocurrió "después de muerto" el P. Núñez. Más de medio siglo después de los sucesos, el error es explicable. Eguiara no podía concebir que, en vida del venerable Núñez, hubiera podido tener Sor Juana otro confesor.

${ }^{120}$ Después de "Barcia”, dice Eguiara entre paréntesis que Sor Juana "también lo había manejado", o sea que también lo había tratado. Pérez de Barcia (cf. supra, p. 596, nota 11) era un hombre atormentado por los escrúpulos. Una vez que había ido a San Jerónimo, "la Madre Juana Inés de la Cruz lo llamaba a que se detuviera, con intento, como ella decía, de probarlo como a escrupuloso", pero él se escabulló (Vida de Pérez de Barcia por Julián Gutiérrez Dávila, 1720, texto citado por MAZA, p. 296, nota 145).

121 En sus Memorias de la congregación del Oratorio (1736), GUTIÉrREZ DÁVILA da una buena precisión en cuanto a esta calidad de "extático". El P. Arellano solía elevarse en éxtasis en la iglesia del convento de San Bernardo (estrenada en 1690), y volaba "desde junto al altar de Santa Bárbara hasta el lugar en donde se halla la pileta de el agua bendita, y de allí hasta el altar mayor" (véase el texto en A. DE ANTUÑANO, art. cit., p. 52). En esas Memorias, por cierto, Gutiérrez Dávila resume lo que dice Eguiara sobre Sor Juana y su relación con los dos santos varones (MAZA, pp. 296-297). 
$Y]$ " Podré gobernarme con las reglas generales" de la Iglesia, como cualquiera de los católicos que viven en el mundo. Sor Juana no le da mucha importancia al hecho de quedar sin director espiritual. Podrá darse el caso de que no haya ningún "theólogo" capaz de sustituir a Núñez. Eso no es motivo de alarma: "en querer más que en saver consiste el salvarse, y esto más estará en mí que en el confesor"' (293). ¡Tantos buenos católicos se salvan sin necesidad de tener un confesor fijo! Es ciertamente bueno que aun los seglares lo tengan, y ella se buscará el suyo, pero sin prisas. La cosa no es tan urgente.

Estará en lo cierto Calleja al decir que, en cuanto a "cumplimiento substancial" de la regla, Sor Juana se portó "como la que mejor"'; pero la zona de lo no "substancial" es enorme, y en ella se incluye toda esa doctrina de la monja comme il faut en que Núñez era especialista, y que para Sor Juana era letra muerta ${ }^{122}$. Por ejemplo, su animada descripción del conflicto en que se vio cuando le encargaron "el Arco de la Iglesia" (57-73) tiene una laguna que salta a la vista. Le pide a Núñez que le ayude "con su clarísimo juicio" a discurrir qué respuesta hubiera debido dar en lance tan apretado: "No puedo", "No quiero", "No sé'”, "Está mal votado", y finge que no se le ocurre la respuesta más obvia: 'Tendré que consultarlo con mi confesor' ${ }^{\prime 23}$. No razona como monja, sino como mujer seglar, como mujer libre.

Lo mismo ocurre cuando habla de sus "estudios privados" (178-189). A su pregunta: “¿Quién los ha prohivido a las mugeres?"' (157), Núñez hubiera podido contestar: 'Esos estudios no se prohiben a las mujeres, sino a las monjas'. Sor Juana tenía que saber que las Metamorfosis y el Orlando Furioso y los versos de amores y las comedias no eran lecturas de monjas. Los "estudios"

${ }^{122}$ Los párrafos que dedicó A. M. P. (SJ, t. 1, p. xxix) a "La exacta religiosa" necesitan muchos addenda et corrigenda.

123 Esto nos da buena base para especular sobre la verdadera relación de Sor Juana con Núñez. En 1676 y 1679 sentía ella que la "venia y licencia" de Núñez para escribir versos (para aceptar sendos encargos de Villancicos) le era más necesaria que la del propio arzobispo (50-52), pero en 1680 no le pide licencia alguna. En cuanto al período 1680-1682, también es revelador lo que dice Sor Juana sobre las "reprehenciones"' de Núñez, hechas públicamente y "no a mí en secreto" (251-252), como hace un buen padre espiritual. Habrá que concluir que en estos años no ha habido mucho trato entre ellos. Evidentemente Núñez ha seguido siendo el confesor de la monja (puesto que en cuanto tal lo despide ella en su Carta), pero ya no el "padre" que amonesta y guía. Y muy bien podemos imaginar que Sor Juana, al confesarse, no se acusaba de cosas que ella tenía por "indiferentes", aunque Núñez las tuviera por "pecado", como tan claramente lo dice ella en la Carta. 
de Santa Catarina y demás santas, que eran de materias sagradas, no vienen muy al caso, pero sirven de puente para llegar al ejemplo del máximo San Jerónimo, que ciertamente incurrió en el mismo "descuido" de Sor Juana: leer a "los poetas y oradores prophanos"' 124 . Del sinnúmero de estos poetas y prosistas no cita ella sino al venerable Aristóteles (puesto que Sócrates y Diógenes no escribieron nada), y deja en silencio todo el montón de libros de materias profanas que se leían en el mundo (y que estaban vedados en los claustros). En cuanto a "hacer versos", cualquier monja devota atendería al confesor que le dijera que eso era "pecado", "delito", "culpa"; pero "yo - dice Sor Juana, con un yo que no es de monja- no sé por qué razón se le pueda llamar assí" (8790). En los versos "no [hallo] yo razón de bien ni de mal, que siempre los he tenido (como lo son) por cosa indiferente" (37-39), $\mathrm{y}$ "el sentir en las materias indiferentes es aquel alius sic et alius sic' (271-272), —o sea: 'A usted le parece esto mal, a mí no', y lo único que se desprende de esta "contradicción" de dictámenes es que "en substancia tanto monta hacer versos como no hacerlos" (263-265). En la Respuesta, 1218-1224, la réplica a los enemigos de los versos es aún más contundente: "Pues si vuelvo los ojos a la tan perseguida habilidad de hacer versos..., viéndola condenar a tantos tanto y acriminar, he buscado muy de propósito cuál sea el daño que puedan tener, y no le he hallado" ${ }_{125}$. Investigación

${ }^{124}$ No podía ignorar Sor Juana que ese "descuido" (esa lectura que técnicamente no era pecado) enćolerizó tanto a Dios, que castigó duramente al santo por medio de unos ángeles ("Grandes azotes le dan / porque a Cicerón leía..."). En cuanto a Santa Gertrudis la Magna -mencionada asimismo, como las demás santas estudiosas, en la Respuesta a Sor Filotea-, seguramente tampoco ignoraba Sor Juana lo que cuenta OVIEDO: Santa Gertrudis "llegó a ser assombro del mundo y admiración de las universidades", pero "con todo esso, porque con la capa de ser regla [so pretexto de ser algo aconsejado en la regla de San Benito] se dedicó más de lo que debía al estudio de las ciencias, y consiguientemente a la correspondencia y trato con los del siglo, la castigó Dios severamente", si no mandándole ángeles azotantes, sí "negándole los consuelos espirituales y cercenando los favores que le hacía". No podía ser más exacta la correspondencia entre la conducta de Santa Gertrudis y la de Sor Juana. Oviedo habla allí por cuenta propia, pero su espíritu estaba identificado con el de Núñez, el cual, en su cartapacio de apuntes, había escrito: "Cuando el estudio y las letras son estorbo para caminar y llegar a la cumbre de la perfección a que deben de precepto aspirar los religiosos y religiosas, se debe mortificar la natural inclinación" (OVIEDO, p. 135). La respuesta de Sor Juana puede expresarse así: 'Yo desconozco el deber, el precepto de llegar a esa cumbre'. Y es claro que no le quitaba el sueño la amenaza del "severo castigo" que sufrió Santa Gertrudis en la esfera mística.

${ }_{125}$ Es notable cómo esta afirmación de la innocuidad de los versos se traba 
hecha "muy de propósito", y totalmente inútil. Ninguno de esos acriminadores tiene razón. De donde se sigue, como bien había observado Tineo, que stultorum infinitus est numerus.

Igualmente laica es la actitud de Sor Juana en cuanto a las visitas de los virreyes (142-144). Ya se ha visto cuál era la actitud de Núñez: a las monjas les está vedado el menor contacto con "los del siglo". Aunque no nos quedaran esos documentos doctrinales, el solo razonamiento que Sor Juana dedica al tema muestra que era esto lo que más le ardía al confesor. Pues bien: el ejemplo del tiempo que el propio Núñez dedicaba a los Mancera - si bien él podía responder "que en los hombres milita otra razón" (168)es el único apoyo o precedente que Sor Juana se da a sí misma para una declaración no ya categórica ("No puedo romper mi relación con esos amables representantes del mundo en que vivo'), sino desafiante ('...y si usted llegara a demostrarme que sí puedo romperla, yo le diría que no quiero').

A todo esto - el hacer versos, el dedicarse a estudios profanos, el tratar con la gente del siglo- se refieren las enérgicas líneas (245-250) en que Sor Juana niega ser solidaria de las monjas " de servil natural" que se pliegan a cuanto el confesor dice, creen en serio que él es "luz del cielo" y "único norte" (cf. supra, p. 613) y aceptan el camino de mortificación que se les traza: ella no es "tan mortificada"' (281). No es lo mismo obediencia que servilismo. "Ojalá y la santidad fuera cosa que se pudiera mandar, que con esso la tuviera yo segura", dice (229-230); "soi tan dócil...", insiste luego (259-262). Nunca ha dejado de cumplir el voto formal de obediencia pronunciado trece años antes. Pero su obediencia no es la obediencia ciega (perinde ac cadaver) pedida

en la Carta con otra igualmente categórica: "la natural repugnancia que siempre he tenido a hacerlos" (45-46); "he rehusado summamente el hacerlos" (36); "[los he hecho] contra mi voluntad" (91); "los aborresco de forma que no avrá para mí penitencia como tenerme siempre haciéndolos"' (265-266). También en la Respuesta abundan estas declaraciones: "Yo nunca he escrito sino violentada y forzada, y sólo por dar gusto a otros; no sólo sin complacencia, pero con positiva repugnancia" (168-170); "El escribir nunca ha sido dictamen propio, sino fuerza ajena”' (183-184). Y hacia el final, inmediatamente después de reafirmar que los versos en sí no son ni buenos ni malos (si los hay malos " no es culpa del arte", sino de quien lo emplea para mal, como sucede "en todas las facultades y ciencias"), declara Sor Juana su repugnancia a hacerlos: "... yo nunca he escrito cosa alguna por mi voluntad, sino por ruegos y preceptos ajenos, de tal manera que no me acuerdo haber escrito por mi gusto si no es un papelillo que llaman el Sueño"' (1264 ss.). Nadie ha tomado en serio esta declaración. Evidentemente, Sor Juana no se refiere sino al escribir por encargo. 
por San Ignacio a sus hijos -y por Núñez a sus hijas-, sino una obediencia iluminada por la razón (246). Está dispuesta a apartarse de cosas que son su "gusto", pero a condición de que Núñez le demuestre que son "escandalosas" 126 . Y si un día decidiera privarse de alguna de ellas, no sería por huir de un pecado - pues todo eso es "mui lícito" - , sino "por mortificarme quando yo quiera hacer penitencia". Los actos de virtud son voluntarios, y lo que los mueve es el amor a Dios. 'Pero yo - parece decir Sor Juana de varias maneras - nunca he presumido de ser un monumento de virtud'. El abstenerse de hacer versos, en la época en que "no los hacía" (42), no fue por amor a Dios, sino "por dar gusto" al confesor, por amor a él. Y el haber aguantado desde 1680 , sin decir esta boca es mía, los vituperios de Núñez, tampoco ha sido un acto virtuoso de "christiana paciencia": no ha sido por merecer algo "para con Dios", por amor a Él, sino por respeto puramente humano a la persona de Núñez (18-20). Pero eso se acabó: "[No estoy dispuesta a hacer] por respectos humanos lo que no hago por Dios" (246-247).

En su réplica a Fernández MacGregor (cf. supra, p. 598) niega don Ezequiel Chávez haber llegado a decir que "la afirmación íntima" de Sor Juana fuera: "Puedo salvarme sin observar las reglas de mi Orden, ni los consejos de mis directores" (CHÁVEZ2 , p. 225). No, no lo dijo, pero su contradictor así lo "leyó", detectando en Chávez un atrevimiento del que él mismo no era consciente. Y la Carta convalida en no escasa medida esa "lectura". Para Sor Juana, lo que contaba era la salvación, no la santificación (y mucho menos las ñoñerías o los excesos que pasan por santificación). Pese a todas las miserias de la vida conventual, eligió el convento porque "era lo menos desproporcionado y lo más decente que podía elegir en materia de la seguridad que deseaba para mi salvación; a cuyo primer respeto (como al fin más importante) cedieron todas las impertinencillas de mi genio"' (Respuesta, 272-276). Lo eligió para proseguir lo que había estado haciendo en el mundo (ibid., 290) manteniéndose a la vez como buena hija de la Iglesia. En lo de "no observar las reglas de la Orden", Fernández MacGregor va demasiado lejos ${ }^{127}$, pero

126 "Si estas reprehenciones cayeran sobre alguna communicación escandalosa mía..., me apartara de ella". Estas palabras no pueden referirse sino a las visitas de los virreyes (comunicación directa con "los del siglo"), —confirmación de que tales visitas eran lo que más andaba reprendiendo Núñez (véase el comienzo de la Carta).

127 Pero sí hay que notar la desenvoltura con que Sor Juana habla de las preladas del convento. La orden de "malear" su forma de letra porque pare- 
en lo de los "consejos de los directores" tiene toda la razón. Sor Juana prescinde de los consejos de Núñez por no necesarios (y aun dañinos) para su idea de la salvación. $Y$ no tiene miedo: “Espero en la bondad de Dios que mi alma no se perderá"' (288). Tal es la esperanza básica de quienes viven en el mundo y de quienes se encierran en un convento, de hombres y mujeres, de doctos e indoctos. ¿A qué, pues, tanta exigencia y tanta alharaca, cuando basta gobernarse "con las reglas generales de la Sancta Madre Iglesia"?

Hay señales visibles de que Sor Juana, unos meses después (a comienzos de 1683), leyó con gran interés, en un tratado del famoso teólogo fray Juan de Jesús María, carmelita, esta clara confirmación de lo que ella dice en su Carta a Núñez: "Es absolutamente cierto [certissimum] que el fin último de los religiosos y de los seglares es uno mismo; mientras vivan de manera justa y decente [sancte recteque], todos ellos se encaminan por igual [simul, al mismo tiempo] a la vida eterna". El tratado a que pertenecen esas palabras está destinado a instruir a los miembros de la orden del Carmen, y a los religiosos en general, sobre la peculiaridad de la vida monástica, que es el progreso in via perfectionis (el teresiano "camino de perfección"). Pero, antes de entrar en materia, el autor deja bien asentada la verdad fundamental: el fin último, igual para todos, es la salvación; el fin que se proponen los religiosos no tiene esa calidad de "último" ("ad... quendam finem... non vltimum... tendunt"') ${ }^{128}$.

cía "de hombre" (Carta, 107-111) fue estupidez pura. (Ella obedeció, claro, pero no con el entendimiento, "teniendo por bueno y mejor cuanto la prelada ordena", ni con la voluntad, "amando y queriendo" esa orden absurda, como pedía Núñez en su Plática doctrinal: cf. supra, p. 612). Seguramente es posterior a la Carta la prohibición de leer que le intimó "una prelada muy santa y muy cándida" (Respuesta, 736), o sea muy tonta.

${ }^{128}$ Se conservan en la Biblioteca Nacional de México los tomos II y III de Opera omnia (Coloniae Agrippinae, 1622-1623) de fray Juan de Jesús María que pertenecieron a Sor Juana. Al final, en una hoja en blanco, hay este autógrafo: "de la Madre Ju. a Ynes de la Cruz religiosa de nuestro Padre San Hieronymo. año de 1683 a 15 de enero"', que es seguramente la fecha de adquisición. El tratado del carmelita ("Tractatus de Religionis nostrae instituto, deque huius fine vel partibus, \& status nostri obligationibus, vt suum hinc alij Religiosi statum perspectum habeant") comienza en la p. 541 del tomo II. La frase que he traducido - "Certissimum est, vltimum religiosorum ac saecularium finem eundem esse: quia omnes, si vitam sancte recteque instituant, simul ad vitam aeternam tendunt" - está subrayada con mucho cuidado (quizá con ayuda de una regla), evidentemente por la propia Sor Juana, igual que otras muchas frases de la misma página, como ésta sobre el carácter primario y esen- 
Z] "No se acuerde de mí si no fuere para encomendarme al Señor". Fue lo que sucedió, en efecto: el P. Núñez "se retiró..., llorando, si no mal logradas, por lo menos no tan bien logradas como quisiera aquellas singularíssimas prendas, mas nunca dexó de encomendar a Dios a su espiritual hija, y sin duda fue effecto de sus missas y oraciones la admirable mudanza de la Madre Juana dos años antes de su muerte..." (OvIEDO).

ANTONIO ALATORRE

El Colegio de México

cial de los mandamientos de Dios y el carácter secundario y puramente instrumental de los consejos evangélicos: "Notandum praeterea, ipsam perfectionem Christianam primario et essentialiter in mandatorum charitatis cum erga Deum, tum erga proximum exercendae obseruatione consistere; secundario vero \& instrumentaliter in consilijs Euangelicis". Estos datos proceden de ERNESTO DE LA TORRE VILlAR, "Autógrafos desconocidos de Sor Juana Inés de la Cruz en un libro más de su biblioteca", $H M B$, pp. 503-512, con 3 fotos. -En su descripción del Epistolario espiritual del mismo fray Juan de Jesús María (Uclés, 1624) dice PALAU, Manual, s.v.: "Algunas epístolas se refieren a Nueva España, en cuyas lejanas tierras habitó el autor". 